Sun, Z., Jian, Z., Stock, J.M., Larsen, H.C., Klaus, A., Alvarez Zarikian, C.A., and the Expedition $367 / 368$ Scientists

Proceedings of the International Ocean Discovery Program Volume 367/368

publications.iodp.org

https://doi.org/10.14379/iodp.proc.367368.101.2018

\section{Expedition 367/368 summary ${ }^{1}$}

Hans Christian Larsen, Zhen Sun, Joann M. Stock, Zhimin Jian,

Carlos A. Alvarez Zarikian, Adam Klaus, Jacopo Boaga, Stephen A. Bowden, Anne Briais, Yifeng Chen, Deniz Cukur, Kelsie A. Dadd, Weiwei Ding,

Michael J. Dorais, Eric C. Ferré, Fabricio Ferreira, Akira Furusawa, Aaron J. Gewecke, Jessica L. Hinojosa, Tobias W. Höfig, Kan-Hsi Hsiung, Baoqi Huang, Enqing Huang, Xiao-Long Huang, Shijun Jiang, Haiyan Jin, Benjamin G. Johnson, Robert M. Kurzawski, Chao Lei, Baohua Li, Li Li, Yanping Li, Jian Lin, Chang Liu, Chuanlian Liu, Zhifei Liu, Antonio Luna, Claudia Lupi, Anders J. McCarthy, Geoffroy Mohn, Lachit Singh Ningthoujam, Michael Nirrengarten, Nobuaki Osono, David W. Peate, Patricia Persaud, Ning Qiu, Caroline M. Robinson, Sara Satolli, Isabel Sauermilch, Julie C. Schindlbeck, Steven M. Skinner, Susanne M. Straub, Xiang Su, Liyan Tian, Froukje M. van der Zwan, Shiming Wan, Huaichun Wu, Rong Xiang, Rajeev Yadav, Liang Yi, Cuimei Zhang, Jinchang Zhang, Yang Zhang, Ning Zhao, Guangfa Zhong, and Lifeng Zhong ${ }^{2}$

Keywords: International Ocean Discovery Program, IODP, JOIDES Resolution, Expedition 367, Expedition 368, Site U1499, Site U1500, Site U1501, Site U1502, Site U1503, Site U1504, Site U1505, northern South China Sea, rifted margin, continent-ocean transition zone, hyperextension, continental breakup, lithosphere thinning, igneous activity, outer margin high, embryonic ocean, steady-state ocean, basalt, altered basalt, greenschist, gravel, Cenozoic, subsidence, T60 unconformity, red clay, turbidite, marine microfossil
Contents

1 Abstract

2 Introduction

3 Background

6 Expedition objectives

7 Coring and logging strategy

10 Site summaries

34 Preliminary scientific assessment

37 References

\section{Abstract}

The primary objectives of International Ocean Discovery Program (IODP) Expedition 367/368 to the northern South China Sea (SCS) margin were to (1) examine its history of continental breakup and (2) compare it with other nonvolcanic or magma-poor rifted margins with the broader goal of testing models for continental breakup. A secondary objective was to further our understanding of the paleoceanographic and environmental development of the SCS and southeast Asia during the Cenozoic. Four primary sites were selected for the overall program: one in the outer margin high $(\mathrm{OMH})$ and three seaward of the $\mathrm{OMH}$ on distinct, margin-parallel basement ridges. These three ridges are informally labeled $\mathrm{A}, \mathrm{B}$, and $\mathrm{C}$ and are located in the continent-ocean transition (COT) zone ranging from the $\mathrm{OMH}$ to the interpreted steady-state oceanic crust (Ridge $\mathrm{C}$ ) of the SCS. The main scientific objectives include the following:
- Determining the nature of the basement in crustal units across the COT of the SCS that are critical to constrain style of rifting,

- Constraining the time interval from initial crustal extension and plate rupture to the initial generation of igneous ocean crust,

- Constraining vertical crustal movements during breakup, and

- Examining the nature of igneous activity from rifting to seafloor spreading.

In addition, the sediment cores from the drill sites targeting primarily tectonic and basement objectives will provide information on the Cenozoic regional environmental development of the Southeast Asia margin.

Site U1499 on Ridge A and Site U1500 on Ridge B were drilled during Expedition 367. Expedition 368 was planned to drill at two primary sites (U1501 and U1503) at the OMH and Ridge C, respectively, but based on drilling results from Expedition 367, Expedition 368 chose to insert an alternate site on Ridge A (Site U1502). In ad-

\footnotetext{
${ }^{1}$ Larsen, H.C., Sun, Z., Stock, J.M., Jian, Z., Alvarez Zarikian, C.A., Klaus, A., Boaga, J., Bowden, S.A., Briais, A., Chen, Y., Cukur, D., Dadd, K.A., Ding, W., Dorais, M.J., Ferré, E.C., Ferreira, F., Furusawa, A., Gewecke, A.J., Hinojosa, J.L., Höfig, T.W., Hsiung, K.-H., Huang, B., Huang, E., Huang, X.-L., Jiang, S., Jin, H., Johnson, B.G., Kurzawski, R.M., Lei, C., Li, B., Li, L., Li, Y., Lin, J., Liu, C., Liu, C., Liu, Z., Luna, A., Lupi, C., McCarthy, A.J., Mohn, G., Ningthoujam, L.S., Nirrengarten, M., Osono, N., Peate, D.W., Persaud, P., Qui, N., Robinson, C.M., Satolli, S., Sauermilch, I., Schindlbeck, J.C., Skinner, S.M., Straub, S.M., Su, X., Tian, L., van der Zwan, F.M., Wan, S., Wu, H., Xiang, R., Yadav, R., Yi, L., Zhang, C., Zhang, J., Zhang, Y., Zhao, N., Zhong, G., and Zhong, L., 2018. Expedition 367/368 summary. In Sun, Z., Jian, Z., Stock, J.M., Larsen, H.C., Klaus, A., Alvarez Zarikian, C.A., and the Expedition $367 / 368$ Scientists. South China Sea Rifted Margin. Proceedings of the International Ocean Discovery Program, 367/368: College Station, TX (International Ocean Discovery Program). https://doi.org/10.14379/iodp.proc.367368.101.2018

2 Expedition 367/368 Scientists' addresses.

MS 367368-101: Published 28 September 2018

This work is distributed under the Creative Commons Attribution 4.0 International (CC BY 4.0) license. (c) BY
} 
dition, Expedition 368 added two more sites on the OMH (Sites U1504 and U1505). Expedition 367/368 completed operations at six of the seven sites (U1499-U1502, U1504, and U1505). Site U1503, however, was not completed beyond casing without coring to $990 \mathrm{~m}$ because of mechanical problems with the drilling equipment that prevented the expedition, after 25 May 2017, from operating with a drill string longer than $3400 \mathrm{~m}$. New alternate Site U1504, proposed during Expedition 367, met this condition. Original Site U1505 also met the operational constraints of the $3400 \mathrm{~m}$ drill string (total) and was an alternate site for the already-drilled Site U1501.

At Site U1499, we cored to $1081.8 \mathrm{~m}$ in 22.1 days with $52 \%$ recovery and then logged downhole data from 655 to $1020 \mathrm{~m}$. In 31 days at Site U1500, we penetrated to $1529 \mathrm{~m}$, cored a total of 1012.8 $\mathrm{m}$ with $37 \%$ recovery, and collected log data from 842 to $1133 \mathrm{~m}$. At Site U1501, we cored to $697.1 \mathrm{~m}$ in 9.4 days with $78.5 \%$ recovery. We also drilled ahead for $433.5 \mathrm{~m}$ in Hole U1501D and then logged downhole data from 78.3 to $399.3 \mathrm{~m}$. In 19.3 days at Site U1502, we penetrated $1679.0 \mathrm{~m}$ in Holes U1502A (758 m) and U1502B (921 $\mathrm{m})$, set $723.7 \mathrm{~m}$ of casing and cored a total of $576.3 \mathrm{~m}$ with $53.5 \%$ recovery, and collected downhole log data from 785.3 to $875.3 \mathrm{~m}$ and seismic data through the $103 / 4$ inch casing. At Site U1503, we penetrated $995.1 \mathrm{~m}$ and set $991.5 \mathrm{~m}$ of $10^{3 / 4}$ inch casing, but no cores were taken because of a mechanical problem with the drawworks. At Site U1504, we took 40 rotary core barrel (RCB) cores over two holes. The cored interval between both holes was $277.3 \mathrm{~m}$ with 26.8\% recovery. An $88.2 \mathrm{~m}$ interval was drilled in Hole U1504B. At Site U1505, we cored $668.0 \mathrm{~m}$ with $101.1 \%$ recovery. Logging data was collected from 80.1 to $341.2 \mathrm{~m}$. Operations at this site covered 6.1 days. Except for Sites U1503 and U1505, all sites were drilled to acoustic basement. A total of 6.65 days were lost due to mechanical breakdown or waiting on spare supplies for repair of drilling equipment, but drilling options were severely limited from 25 May to the end of the expedition by the defective drawworks limiting deployment of drill string longer than $3400 \mathrm{~m}$.

At Site U1499, coring $200 \mathrm{~m}$ into the interpreted acoustic basement sampled sedimentary rocks, possibly including early Miocene chalks underlain by Oligocene polymict breccias and poorly cemented gravels of unknown age comprising sandstone pebbles and cobbles. Preliminary structural and lithologic analysis suggests that the gravels might be early to late synrift sediment. At Site U1500, the main seismic reflector corresponds to the top of a basalt sequence at $\sim 1379.1 \mathrm{~m}$. We cored $149.90 \mathrm{~m}$ into this volcanic package and recovered $114.92 \mathrm{~m}$ (77\%) of sparsely to moderately plagioclase-phyric basalt comprising numerous lava flows, including pillow lavas with glass, chilled margins, altered veins, hyaloclastites, and minor sediment. Preliminary geochemical analyses indicate that the basalt is tholeiitic.

Sampling of the Pleistocene to lower Miocene sedimentary section at Sites U1499 and U1500 was not continuous for two reasons. First, there was extremely poor recovery in substantial intervals interpreted to be poorly lithified sands, possibly turbidites. Second, we chose to drill down without coring in some sections at Site U1500 to ensure sufficient time to achieve this site's high-priority deep drilling objectives. The upper Miocene basin sequence, which consists of interbedded claystone, siltstone, and sandstone can be correlated between the two sites by seismic stratigraphic mapping and biostratigraphy.

At Site U1501 on the OMH, coring $45 \mathrm{~m}$ into the acoustic basement sampled prerift(?) deposits comprising sandstone to conglomerate of presumed Mesozoic age. These deposits are overlain by siliciclastic synrift sediments of Eocene to Oligocene age followed by primarily carbonaceous postrift sediments of early Mio- cene to Pleistocene age. Site U1502 on Ridge A was cased to 723.7 $\mathrm{m}$. No coring was attempted shallower than $380 \mathrm{~m}$ to save operational time and because of low expectations for core recovery in the upper Plio-Pleistocene sequence. At this site, we recovered $180 \mathrm{~m}$ of hydrothermally altered brecciated basalts comprising sheet and pillow lavas below deep-marine sediments of Oligocene to late Miocene age. At Site U1503 on Ridge C, $991.5 \mathrm{~m}$ of casing was installed in preparation for the planned deep drilling to $\sim 1800 \mathrm{~m}$. No coring was performed due to mechanical failures, and the site was abandoned without further activity except for installation of a reentry cone. Coring at Site U1504 on the OMH, located $\sim 4 \mathrm{~km}$ east of Site U1501, recovered mostly foliated, greenschist facies metamorphic rocks below late Eocene(?) carbonate rocks (partly reef debris) and early Miocene to Pleistocene sediments. At Site U1505, we cored to $480.15 \mathrm{~m}$ through Pleistocene to late Oligocene mainly carbonaceous ooze followed at depth by early Oligocene siliciclastic sediments.

Efforts were made at every drill site to correlate the core with the seismic data and seismic stratigraphic unconformities interpreted in the Eocene to Plio-Pleistocene sedimentary sequence prior to drilling. The predrilling interpretation of ages of these unconformities was in general confirmed by drilling results, although some nontrivial corrections can be expected from detailed postexpedition work on integrating seismic stratigraphic interpretations with detailed bio- and lithostratigraphy.

As a result of the limited length of drill string that could be deployed during the later part of Expedition 368, the secondary expedition objectives addressing the environmental history of the SCS and Southeast Asia received more focus than originally planned, allowing Site U1505 (alternate to Site U1501) to be included. Despite this change in focus, Expedition 367/368 provided solid evidence for a process of breakup that included vigorous synrift magmatism as opposed to the often-favored interpretation of the SCS margin as a magma-starved margin or a margin possibly overprinted at a much later stage by plume-related magmatism. In this broader perspective, Expedition 367/368 accomplished a fundamental objective of the two-expedition science program.

\section{Introduction}

The South China Sea (SCS) margin (Figure F1) is an accessible and seismically well-imaged location where drilling of synrift sediment and underlying basement will provide key constraints on the processes of rifting and eventual rupturing of the continental lithosphere during breakup at a highly extended rifted margin. Expedition 367/368 was based on International Ocean Discovery Program (IODP) drilling Proposals 878-CPP, 878-Add, 878-Add2, and 878Add3. This project was implemented as a single science program with 114 days of drilling operations spread across two IODP expeditions as outlined in the Expedition 367/368 Scientific Prospectus (Sun et al., 2016b). Two expeditions were required to drill four highpriority, deep-penetration sites in a transect across the margin. Of these, three sites targeted acoustic basement in the continentocean transition (COT), and one site targeted prerift through synrift to postrift sequences on the landward side of the transect. Although the primary focus of this drilling expedition was to discriminate among possible models for rifting and plate rupture, the drilling, along with results from Ocean Drilling Program (ODP) Leg 184 and IODP Expedition 349, addressed a secondary objective to improve our understanding of the Cenozoic environmental evolution of the southeast Asian area as recorded in the sediments of the SCS basin. 
Figure F1. Seismic data coverage and magnetic anomalies in the SCS basin, Expedition 367/368. Black lines = ocean-bottom seismometer (OBS) refraction data. Other seismic lines are mostly multichannel seismic reflection data. Yellow lines = magnetic isochrons (labeled with white text) from Briais et al. (1993). White stars = Expedition 367/368 drill sites. ODP Leg 184 (red squares) and IODP Expedition 349 (red circles) sites are shown with site numbers. For more details, see Figure F4.

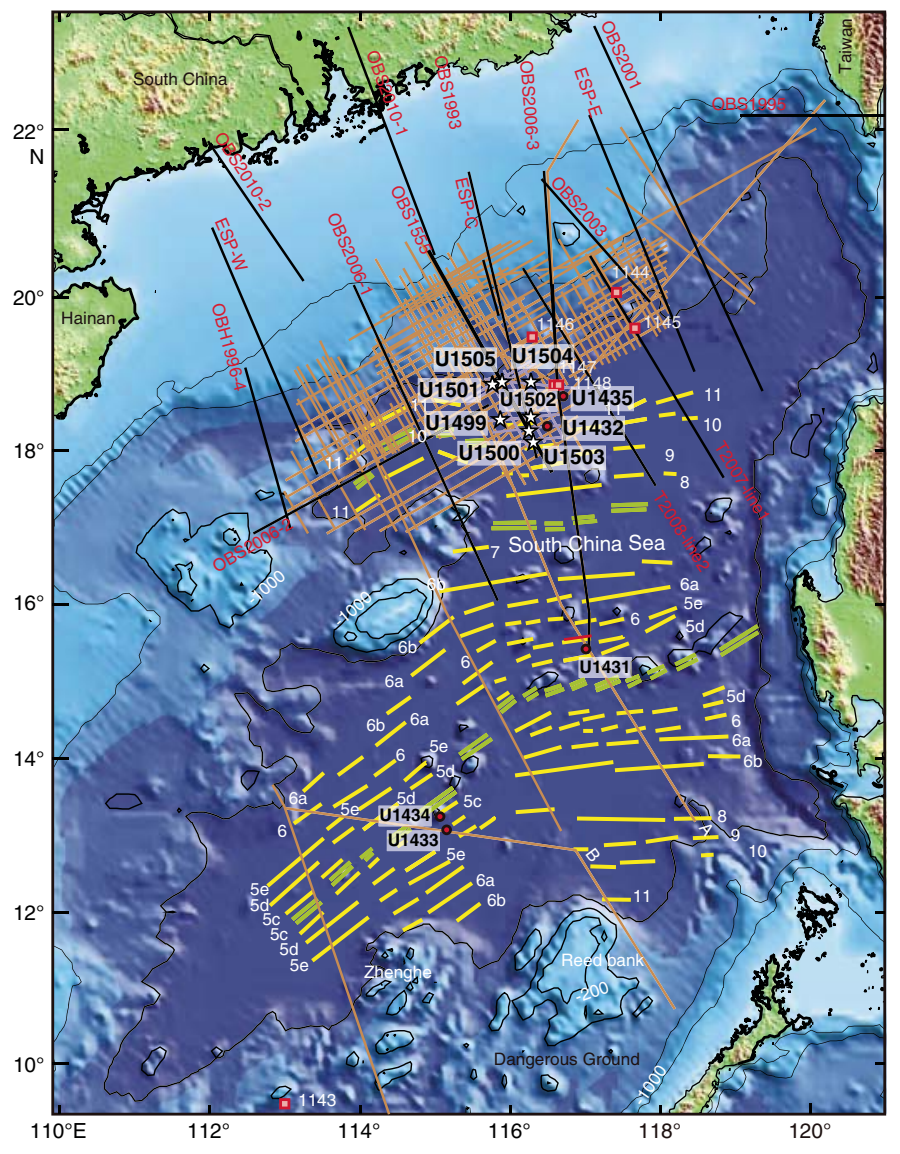

\section{Background \\ Global questions regarding formation of rifted margins}

ODP (1985-2003) made a major effort along the rifted margins of the North Atlantic to understand the processes of continental breakup (ODP Legs 103, 104, 149, 152, 163, 173, and 210). This effort resulted in the recognition of two end-members of rifted margins (see summary of observations in Sun et al., 2016a, 2016b).

The first recognized end-member is referred to as a volcanic rifted margin, examples of which are characterized by massive igneous activity in a relatively short period of time ( $\sim 1-3$ million years) during breakup and initial seafloor spreading. The pair of conjugate margins of Greenland and northwest Europe is a type example. In these locations, the asthenospheric mantle may have been anomalously hot (e.g., mantle plumes), leading to thermal weakening of the continental lithosphere followed by rapid plate rupture (Duncan, Larsen, Allan, et al., 1996; Eldholm et al., 2000; Geoffroy, 2005).

The second recognized end-member is the hyperextended, magma-poor rifted margin, which is interpreted to endure hyperextension of the continental crust, with tectonic extension at the distal margin leading eventually to serpentinization and exhumation of the subcontinental mantle. The Newfoundland and Iberia conjugate margin, where serpentinized exhumed mantle occupies a broad zone in the COT, is an example of this type of margin (Boillot, Winterer, et al., 1988; Whitmarsh, Sawyer, Klaus, and Masson, 1996; Beslier, Whitmarsh, Wallace, and Girardeau, 2001). However, it is the only conjugate margin pair where geophysical interpretation has been confirmed by scientific drilling. The introduction of water to the subcontinental lithospheric mantle is interpreted to have taken place through deep, crust-cutting faults, causing serpentinization that profoundly weakens the mantle lithosphere and facilitates plate rupture. The subsequent ultraslow spreading led to formation of additional serpentinite on the seafloor (e.g., Dick et al., 2003) until sufficient magma production for normal oceanic crust to form was established.

Other examples of hyperextended rifted margins have been interpreted from seismic reflection data (e.g., Brune et al., 2017; Doré and Lundin, 2015). However, it is not known if serpentinized mantle plays a critical role in all cases. Modeling by Huismans and Beaumont $(2008,2011)$ suggests several scenarios for the formation of rifted margins in the absence of anomalously hot asthenospheric mantle. One scenario (Type I of Huismans and Beaumont, 2011) is the Iberia-Newfoundland-type margin described above. In this case, lithospheric thinning initially occurs in the (upper) crust, with extensional faults profoundly thinning the continental crust (hyperextension) and eventually reaching the mantle and causing serpentinization (Whitmarsh et al., 2001; Pérez-Gussinyé and Reston, 2001; Pérez-Gussinyé et al., 2006; Reston, 2009; Sutra and Manatschal, 2012). The schematic model of this type of margin development, shown in Figure F2, guided the drilling strategy of Expedition 367/368. Huismans and Beaumont (2008, 2011), however, also suggest that final plate rupture can occur without exhumation of the subcontinental mantle and can be followed rather quickly by igneous oceanic crust formation, a scenario that our chosen drilling strategy also tested. The highly extended northern margin of the SCS is therefore an excellent location to examine through drilling whether this margin experienced magmatism during breakup or its development is closer to the Iberia-type, amagmatic margin.

\section{Geological setting}

The SCS is a modestly sized young ocean basin that formed along the eastern boundary of the Eurasian plate during mid- to late Cenozoic time (Figure F1). Expedition 367/368 cored and logged a transect of drill sites across the COT in the northern SCS (Figure F3).

Before the continental crust rifted to form the present SCS, there used to be a subduction zone in the late Mesozoic along the southeast part of the South China block (Zhou and Li, 2000; Zhou et al., 2008; Li et al., 2012a, 2012b). This relatively young continental lithosphere subsequently underwent extensive rifting during the Paleogene, likely in the Eocene and early Oligocene. Seafloor spreading in the SCS started during the Oligocene, with the oldest interpreted magnetic anomaly in the area of the drilling transect interpreted to be Anomaly C11 ( 29.5 Ma) or possibly C12n ( 31 Ma) (Briais et al., 1993; Li et al., 2013, 2014; Franke et al., 2013). Seafloor spreading then started to propagate into the Southwest Subbasin at $\sim 23 \mathrm{Ma}$ (Briais et al., 1993; Barckhausen and Roeser, 2004; Li et al., 2012a, 2012b; Franke et al., 2013).

The initial half-spreading rate may have been as high as $\sim 3.6 \mathrm{~cm} / \mathrm{y}$, later slowing to $1.2 \mathrm{~cm} / \mathrm{y}$ with seafloor spreading to eventually cease by $\sim 15 \mathrm{Ma}$ ( $\mathrm{Li}$ et al., 2014). The initial spreading rate in the SCS basin is therefore higher than the ultraslow spreading scenario of the Iberia-Newfoundland margin (Dick et al., 2003). 
Figure F2. A-D. Schematic development of continental breakup initiated by a simple shear along a deep, low-angle fault. B-D are slightly modified from Huismans and Beaumont (2011) and illustrate modeling-based stages of extension at magma-poor, Iberia-Newfoundland type rifted margins. Key features of $D$ are thinning of the upper crust, juxtaposition of lower crust with serpentinized mantle between the outer margin and igneous oceanic crust. UP = upper plate, LP = lower plate. The Expedition 367/368 drilling strategy was designed to sample and test whether or not these fundamental crustal units and tectonic relationships are present at the northern SCS rifted margin.
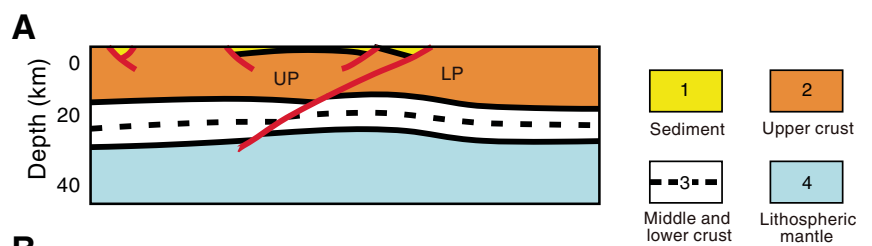

B
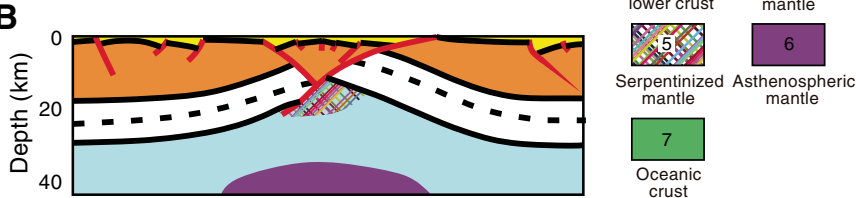

C
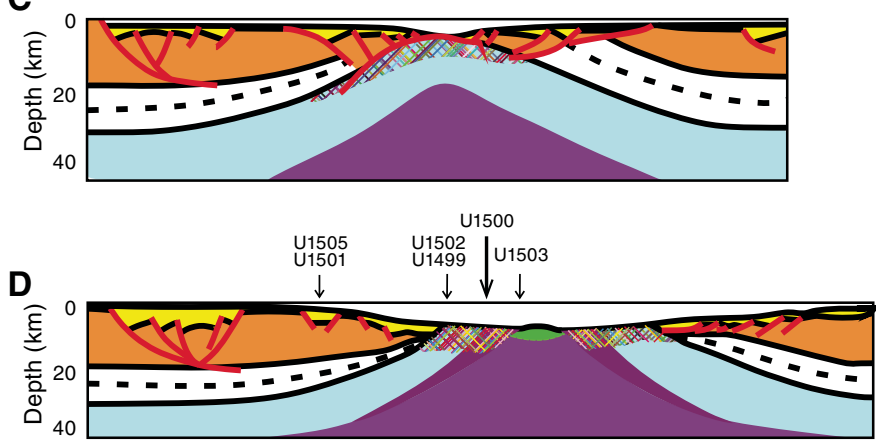

Subduction of the eastern part of the SCS basin started at or before $\sim 15 \mathrm{Ma}$ along the Manila Trench (Li et al., 2013). For a more complete review of the regional setting and tectonic development of the SCS, see Shi and Li (2012), Franke et al. (2013), Li et al. (2013), and Sun et al. (2014).

The Expedition $367 / 368$ drilling transect is located $\sim 50 \mathrm{~km}$ west of IODP Site U1435 along the northern SCS margin (Figures F1, F3) (Li et al., 2015a, 2015b). A transform fault defines a western boundary of a margin segment that exhibits a broad zone of crustal extension (Figure F4). This broad zone of extension (COT) may end to the east somewhere between Sites U1432 and U1435. East of this position, continental crust seems to thin into ocean crust in a much narrower COT. It is therefore conceivable that a kind of crustal transform zone is present in this location and defines an eastern end of a margin segment characterized by a high degree of crustal extension.

The segment of the SCS margin addressed by Expedition $367 / 368$ is characterized by a relatively broader COT $(\sim 80 \mathrm{~km})$ of crustal stretching and extension (Figure F5) prior to breakup and stretches for nearly $100 \mathrm{~km}$ between longitudes $115^{\circ} 35^{\prime} \mathrm{E}$ and $116^{\circ} 30^{\prime} \mathrm{E}$. A deep sag basin (midslope basin [MSB]) of presumed Eocene to Oligocene age is present in the midslope area and is bounded seaward by an outer margin high $(\mathrm{OMH})$, forming a quite persistent structure along the margin. Three distinct ridges (A, B, and $\mathrm{C}$ in Figure F4) are found seaward of the $\mathrm{OMH}$ in the more distal margin and on progressively thinner crust in the COT. We refer
Figure F3. Bathymetric maps showing Expedition 367/368 sites (stars), and (A) regional and (B) local coverage of multichannel seismic reflection data and OBS data. Thick blue and red lines are key seismic lines used for planning of the drilling transect. A. Magnetic isochrons (orange lines) from Briais et al. (1993). B. Magnetic picks (orange squares) from the same reference, extracted from the Seton et al. (2014) compilation. Chron labels for the picks correspond to the old edge of the normal polarity intervals (see Ogg et al. [2016] timescale for ages). Orange square $=$ Leg 184 Site 1148, yellow squares $=$ Expedition 349 Sites U1432 and U1435.

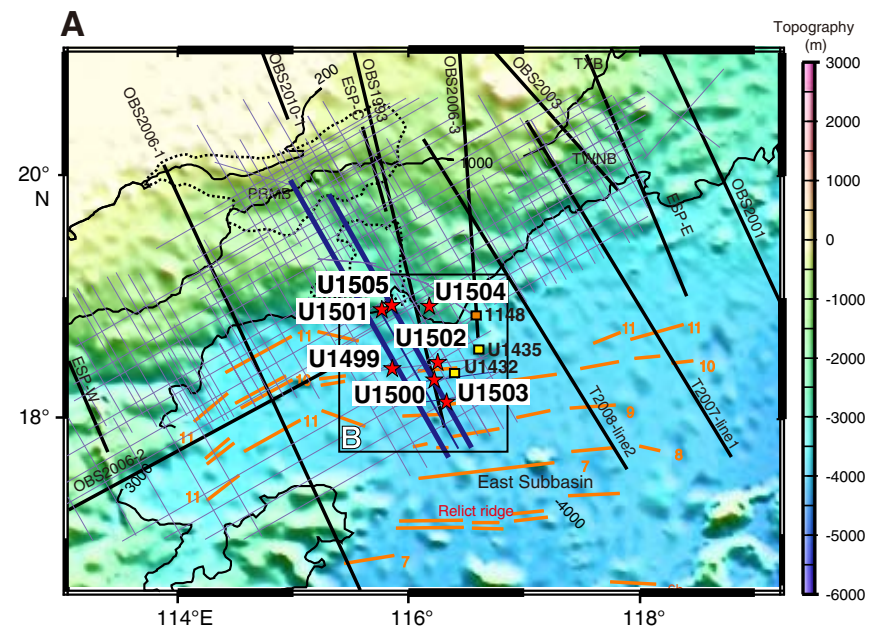

B

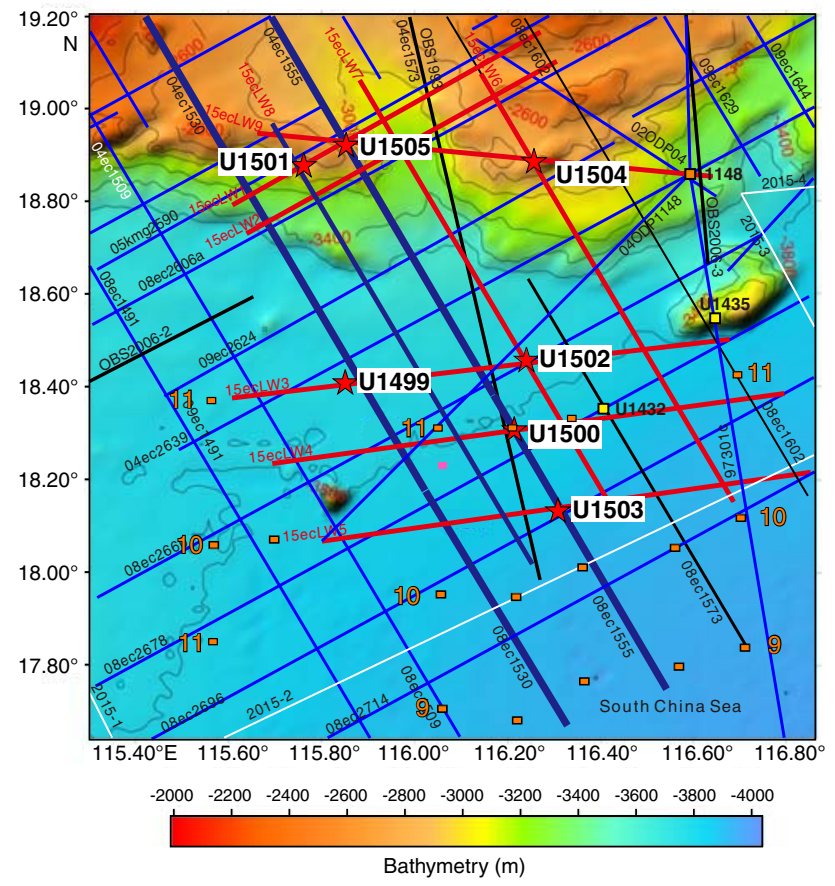

to the continent/ocean boundary (COB) as the much narrower zone in which the outermost, highly thinned continental lithosphere is replaced seaward by new crust that formed in a narrow zone at a spreading ridge in a steady-state fashion. The latter can include continuous tectonic exhumation of rising lithospheric or asthenospheric mantle (e.g., Dick et al., 2003), accretion of normal igneous oceanic crust, or a mixture of these two processes. Constraining the nature and location of the $\mathrm{COB}$ at the SCS will require integrated interpretation of deep crustal reflection normal and wide-angle incidence seismic data and deep sampling by drilling. 
Figure F4. Two-way traveltime to (A) acoustic basement (Tg reflector) and (B) Unconformity T60 and location of Expedition 367/368 sites. Proposed drilling transect (thick black line) was located approximately at the center of a margin segment bounded to the southwest by a transform fault. Northeastern boundary of margin segment is located around Expedition 349 Site U1435. In this location, the outer margin high and Ridge A seem to coalesce, and Ridges $B$ and $C$ of the COT become indistinct toward the northeast within the next margin segment. Note that outer margin high is slightly east-northeast to the more parallel Ridges A, B, and C.
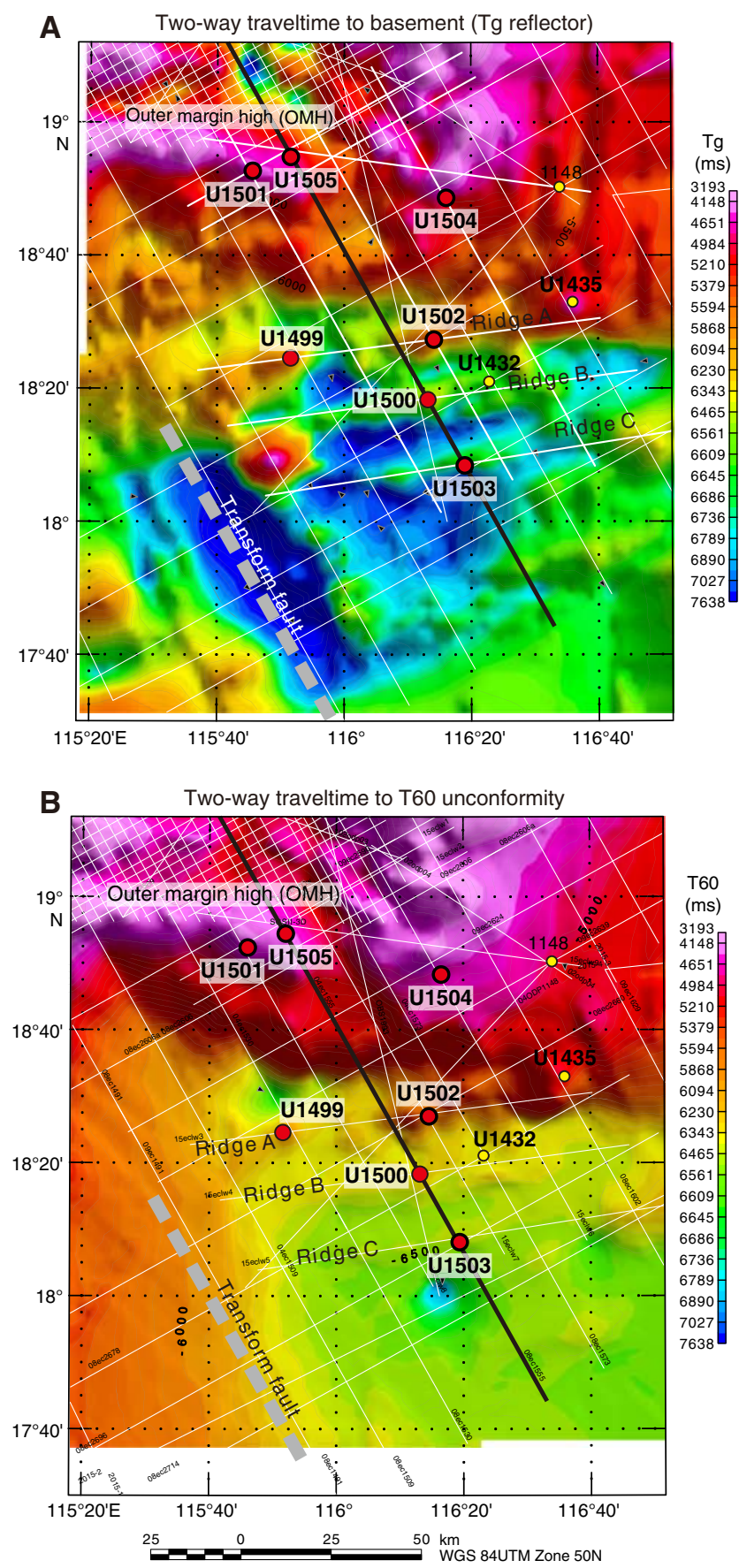

The clear seismic reflections from the Mohorovičić seismic discontinuity (Moho) show distinct thinning of the continental crust (Figure F5) across the COT with a thickness of $\sim 6 \mathrm{~km}$ around the seaward end. Separate layers hypothesized to be upper, middle, and lower crust are present in the landward part of these seismic pro- files. The lower crust is acoustically transparent and may in places be as thin as $\sim 6 \mathrm{~km}$. Lower crust with a similar thickness and seismic appearance is reported from the northeastern SCS margin (McIntosh et al., 2013, 2014; Lester et al., 2013). The seaward continuation of this crustal layering into the $\mathrm{COB}$ is, however, ambiguous, and prevents us from interpreting the detailed nature of the $\mathrm{COB}$ at this point.

The upper crust shows numerous extensional, low-angle detachment faults soling out at midcrustal levels. This fault system generated a number of deep half-grabens filled with synrift sediments that were subsequently covered by postrift sediments. The boundary between synrift and postrift sediments may follow the seismic stratigraphic unconformity named T70 (Figure F5). Industry data from distant wells suggest a breakup unconformity age of $\sim 34 \mathrm{Ma}$. However, this age of T70 may be subject to revision, and in addition, the time of crustal extension is not necessarily synchronous across the margin and could be younger toward the outer margin. A younger, widely distributed unconformity (T60) is also shown in Figure F5. The T60 unconformity corresponds to a hiatus at $\sim 23$ Ma found at ODP Site U1148 (Shipboard Scientific Party, 2000) and IODP Site U1435. T60 is approximately synchronous with a southward jump of the SCS spreading axis (Briais et al., 1993). However, the age of T60 may also be subject to revision, and the relationship between a ridge jump and a margin-wide unconformity and seismic sequence boundary remains speculative at this point.

The OMH hosts a number of relatively shallow half-graben basins on top of this broad basement high. The stratigraphy of these smaller basins can be traced seismically into the deeper, central basin sag below the MSB (Figure F5). The normal faults bounding these $\mathrm{OMH}$ basins are clearly imaged and, for the main part, dip seaward. These small rift basins, therefore, offer an opportunity to sample the stratigraphy covering the entire period of rifting and postrift subsidence. The MSB itself is bounded landward by major, seaward-dipping normal fault(s) seemingly forming major detachments soling out at middle to lower crustal levels but not penetrating through the lower crust. This suggests decoupling between the upper and lower crust and, at least in this more landward part of the margin, faults never penetrated the lower crust, which may have remained ductile and resistant to faulting.

The lower crust in the COT may thicken seaward (lower crustal flow?), but this interpretation is not well constrained (Figure F5). Likewise, seismic imaging of the low-angle faults and detachments in the landward part of the COT cannot, with confidence, be traced into the distal margin regime south of the $\mathrm{OMH}$. One possibility is that the main detachment zone was located above what later became Ridge A, effectively implying that Ridge A is a core complex consisting of lower continental crust or subcontinental mantle, depending on how deeply detachments exhumed the lithosphere in the distal margin. Alternatively, if the main detachment underlies Ridge A, this structure would represent upper plate material of upper crustal origin.

Ridge A is for the most part dome-like, showing neither normal faults nor clearly developed synrift half-grabens like the OMH. Excluding postrift sediments, the crust below this outermost basement high is only $\sim 6-8 \mathrm{~km}$ thick using the ocean-bottom seismometer velocity constraints of Yan et al. (2001), Wang et al. (2006), and Wei et al. (2011). Seaward of Ridge A and across ridges $\mathrm{B}$ and $\mathrm{C}$, the crust has a fairly uniform thickness of $\sim 6 \mathrm{~km}$, which could be consistent with oceanic crust (Yan et al., 2001). The oldest linear magnetic anomaly that can be confidently mapped along this margin segment is interpreted as magnetic Chron C11n based on 
Figure F5. Deep crustal time-migrated seismic reflection data without and with interpretation. Note the rather thin lower crust (two layers) above a strong Mohorovičić seismic discontinuity (Moho) reflector that can be followed oceanward. Moho reflection is weak to absent seaward from around the interpreted COT. Wide-angle seismic data (Yan et al., 2001) confirm 6 km thick ocean crust (OC) seaward of the COT. A large detachment fault 150 km inland of the COT separates more stable crust landward from that of highly extended crust seaward. An OMH is a fairly consistent feature along this margin segment. Key seismic unconformities are shown in purple (T70; 32 Ma breakup unconformity?) and blue (T60; 23 Ma regional basin event). These ages are inferred from longdistance $(>100 \mathrm{~km}$ ) correlation of seismic unconformities with industry holes and ODP Leg 184 Site 1148 (T60); ages need confirmation by coring and are only tentative. $\mathrm{Tg}$ (black) is basement. Arrows = approximate position of seafloor magnetic anomalies with chron numbers. Seismic data are from Line 04ec155508 ec1555 (courtesy of Chinese National Offshore Oil Corporation [CNOOC]). Location of line is shown in Figure F3. CDP = common depth point. C11n, C10n, and $C 9 n=$ approximate location of normal polarity magnetic isochrons. MSB = midslope basin.
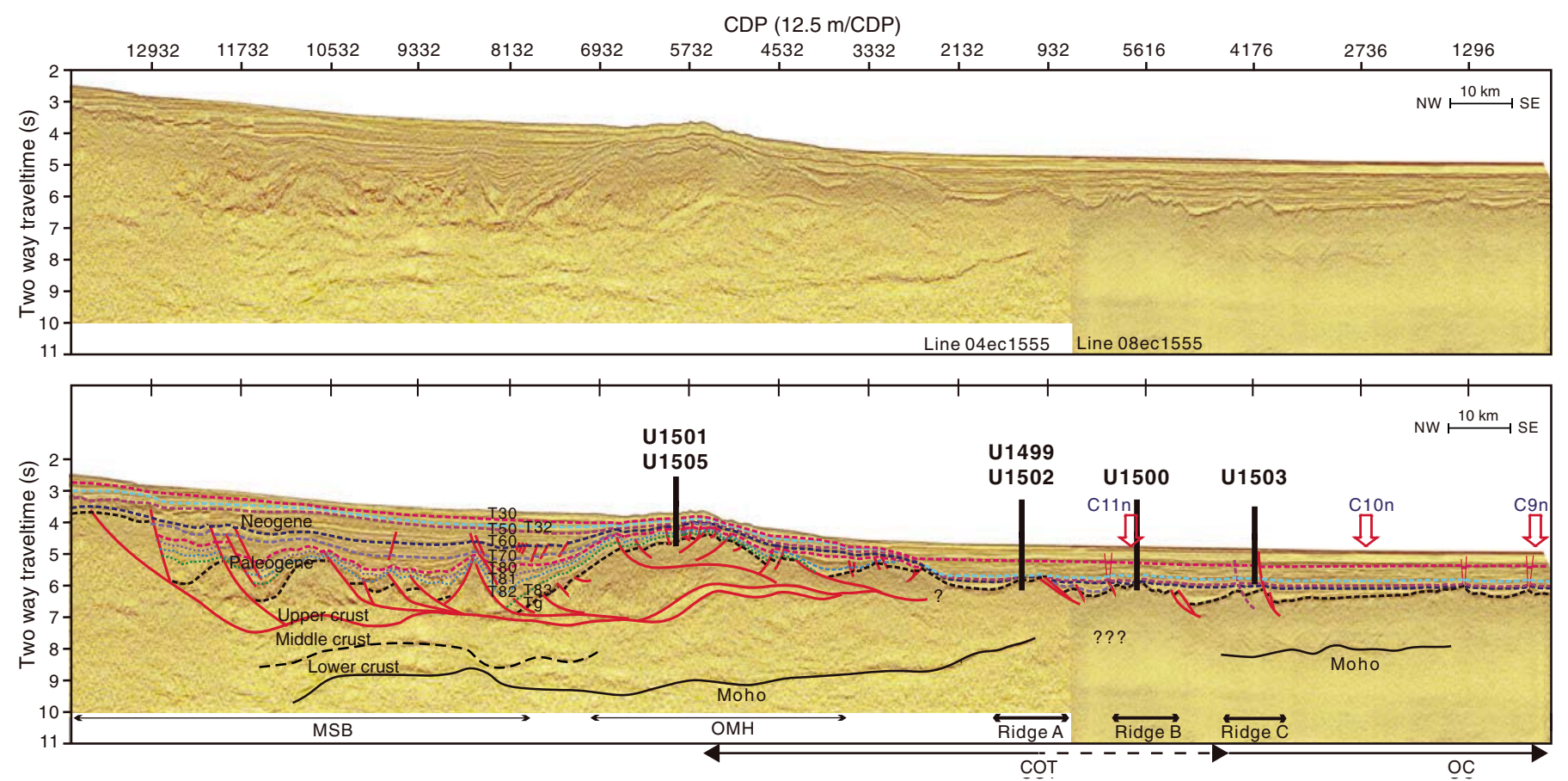

total magnetic field data; the corresponding magnetic high is located $\sim 10 \mathrm{~km}$ seaward (south) of Ridge B (Figure F5). However, if this position is corrected by deskewing the magnetic data, the magnetic high corresponding to C11n with an age of $\sim 29.5-30$ Ma will be located more or less on top of Ridge B (Figure F5).

Both Ridges $B$ and $C$ consist of fault blocks tilted landward along seaward-dipping normal faults (Figure F5). Ridge B shows seismic features along strike and in the uppermost crust that could be consistent with a volcanic origin. However, without drilling constraints, these features could also be interpreted as prerift deposits below the seismic unconformity that defines the top of acoustic basement at Ridge B. Ridge $C$ is seismically similar in many ways to Ridge B. However, an apparent reversed magnetic anomaly (C10r; $29 \mathrm{Ma}$ ) strongly suggests that this ridge indeed represents close to if not full igneous oceanic crust.

Sampling the basement at Ridges A, B, and C was therefore essential for Expedition 367/368 to distinguish between different tectonic models for breakup along highly extended margins. Ridges A and B in particular help constrain the style of rifting and to determine if the SCS margin indeed succeeded to the stage of a hyperextended margin or not. Ridge $C$ is assumed to represent the early igneous crust, and samples from this ridge will constrain the nature of early oceanic crust formation, specifically how quickly a robust igneous system was established, what mantle source was involved (e.g., composition, temperature), what conditions of mantle melting (degree and depth of melting) ruled, and, if any, type and amount of continental crustal contamination of the igneous material derived from the asthenospheric mantle.

\section{Expedition objectives}

The two-expedition drilling transect across the SCS margin set out to understand the timing and process of rifting, the eventual rupturing of the continental crust, and the onset of breakup-related magmatism at the SCS rifted margin (Figure F2). Four primary and sixteen alternate drill sites across a $\sim 150 \mathrm{~km}$ wide COT zone were defined in the Scientific Prospectus (Sun et al., 2016b). The four primary sites targeted the four main tectonic features (the $\mathrm{OMH}$ and its small rift basins) and the nature of the three ridges in the distal margin (Ridges A, B, and C). At each of these sites, the nature of the acoustic basement and the record of synrift and postrift deposits were key targets.

Results from the OMH site (U1501) in particular will address the rifting history and provide constraints on the degree of crustal exhumation, if any, in the OMH. Located off the distal margin and in relatively thick crust, the subsidence history at this site can be compared with that of the more distal margin, which suffered a much higher degree of crustal thinning. Sampling of prerift through synrift to postrift sediments in one of the rotated fault blocks at the $\mathrm{OMH}$ can constrain the timing of rifting and rate of extension in a location where results can be tied to the much deeper rift basins further landward through a dense grid of high-quality 2-D seismic data provided by the Chinese National Offshore Oil and Gas Company (CNOOC). The site has the further advantage of a water depth shallower than the other three primary sites and, importantly, above the present carbonate compensation depth (CCD). It therefore has 
the potential to yield a rich record of carbonate sediments for detailed paleoclimate studies using stable isotope techniques.

Ridge A in particular will be important for constraining whether this ridge is a core complex representing lower plate material (mantle of lower crust), upper plate extensional fault block, or igneous material related to breakup. Ridge B provides an option to distinguish between possible unroofed, lower plate material, upper plate extensional fault block, and igneous material related to incipient seafloor spreading. Ridge $\mathrm{C}$, as described above, targeted sampling a time series of early ocean floor volcanism to establish a reference frame for understanding and modeling the igneous development of the margin.

Except for coring at Ridge C, where operations came to a halt for technical reasons, Expedition 367/368 completed all the above objectives. Expedition 367 drilled two of the primary sites (U1499 and U1500) on Ridges A and B (Figures F2, F3, F4, F5). Coring at Site U1499 on Ridge A recovered synrift or prerift sediments below the acoustic basement. Coring at Site U1500 successfully sampled 150 $\mathrm{m}$ of submarine basaltic lavas, including pillow lavas, below the acoustic basement at Ridge B. Expedition 368, which originally set out to drill the remaining two primary sites on Ridge C (U1503) and the OMH (Site U1501), added a second, alternate site on Ridge A (Site U1502) to improve the characterization of this ridge and recovered a $180 \mathrm{~m}$ thick sequence of submarine basaltic lavas. A successful drilling strategy (see Coring and logging strategy), however, allowed us to also pursue Site U1503 on Ridge C, but after installation of casing at this site, the hole had to be abandoned for technical reasons. This decision left time for inserting alternate Sites U1504 and U1505, both at shallower water depths on the $\mathrm{OMH}$. Two of the OMH drill sites penetrated to acoustic basement and found Mesozoic prerift? sediments (Site U1501) and metamorphic schist (Site U1504). Site U1505 provided 100 percent recovery of a very complete Oligocene to Plio-Pleistocene sediment sequence.

\section{Coring and logging strategy}

Drilling operations were designed to core and log through thick sediment sections and, significantly, into underlying basement using casing in the upper and unstable part of the sedimentary sections. Initially, the operational approach was to drill two holes per site (Figures F6, F7).

The first hole at each site would be cored with the advanced piston corer (APC) and extended core barrel (XCB) systems to refusal (or maximum casing depth) and then logged with the triple combination (triple combo) and Formation MicroScanner (FMS)-sonic tool strings. The APC/XCB hole would also document borehole and formation conditions to help determine the length of casing for drilling a second hole (B). All full APC cores were intended to be oriented, and formation temperature measurements would be made using the advanced piston corer temperature tool (APCT-3).

The second hole at each site was designed to begin by drilling in a seafloor reentry system with casing extending to $\sim 650 \mathrm{~m}$ or an otherwise defined depth (Figures F8, F9, F10, F11). Casing is drilled down through the reentry cone using an extendable underreamer and mud motor technology (see https://rosetta.iodp.tamu.edu/ A/TechDoc/8250). Following the installation of casing to the desired depth, coring using the RCB system could then extend from the base of the casing through the sediment and into the underlying basement. Multiple pipe trips to replace hard rock RCB bits would be made as required by the depth of the target in basement. Upon completion of the coring objectives, the RCB bit would be dropped either at the bottom of the hole or on the seafloor before downhole wireline logging was conducted. For this deeper logging, we planned to use the triple combo and FMS-sonic tool strings along with the Versatile Seismic Imager (VSI) tool string to conduct check shots.

During Expedition 367/368, we had to modify this general operational plan in response to borehole conditions and the need to fo-

Figure F6. Implemented Expedition 368 operations.TD = total depth.

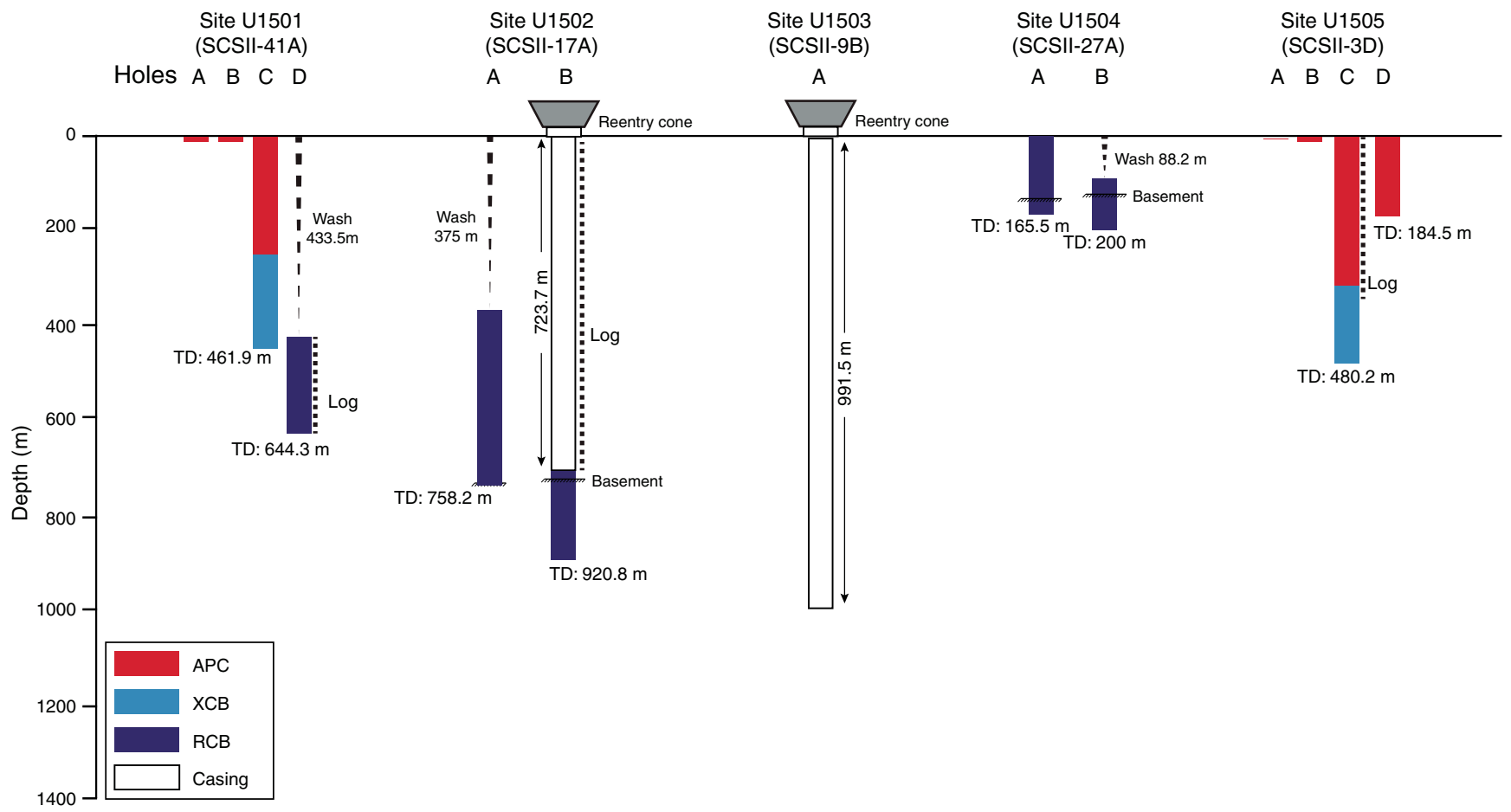


Figure F7. Planned and implemented Expedition 367 operations.

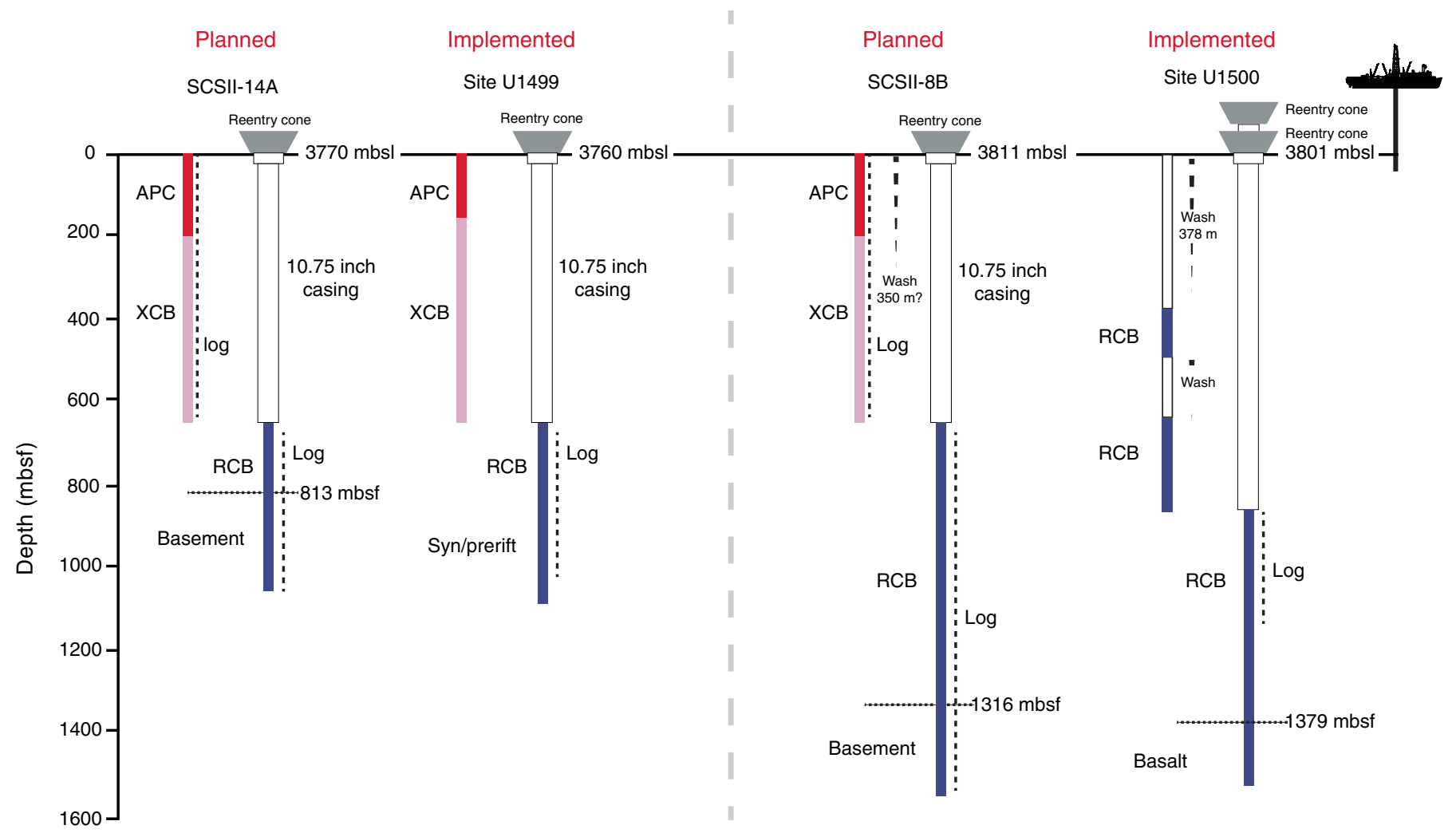

Figure F8. Reentry system and casing, Hole U1499B.
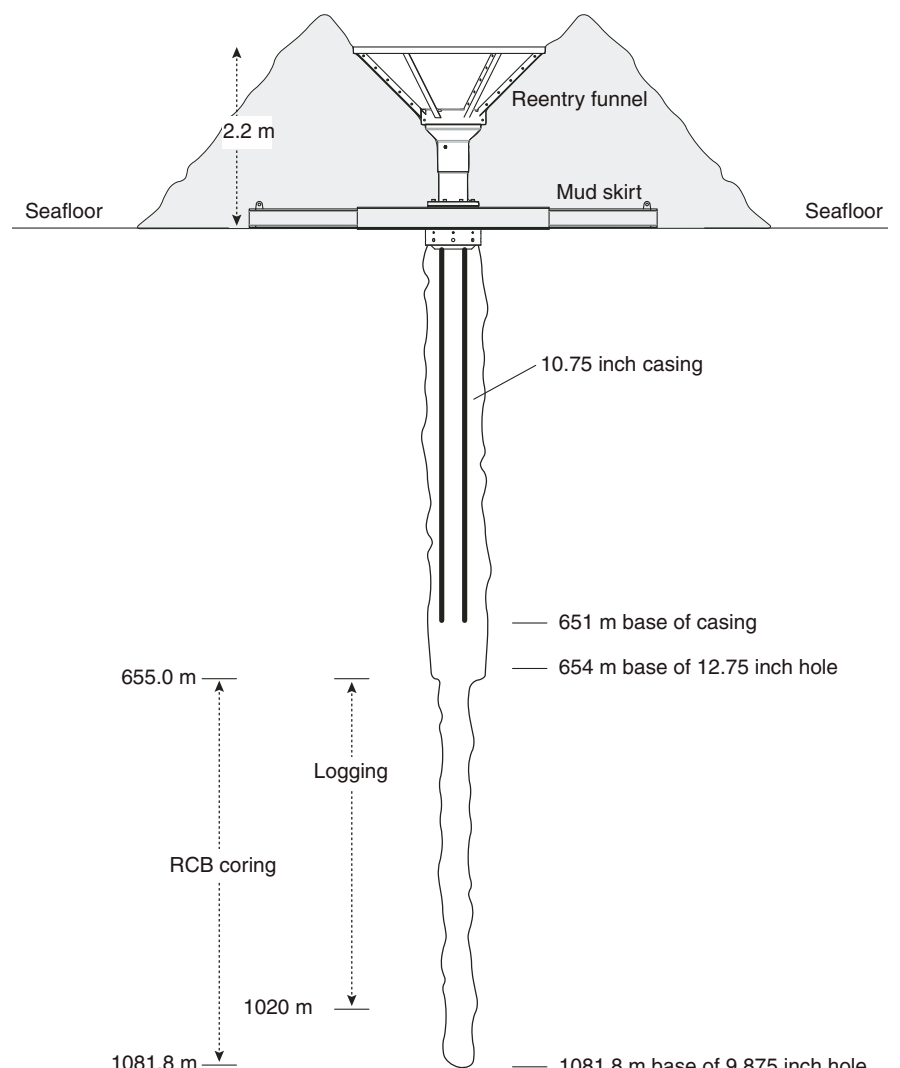

Figure F9. Reentry system and casing, Hole U1500B.

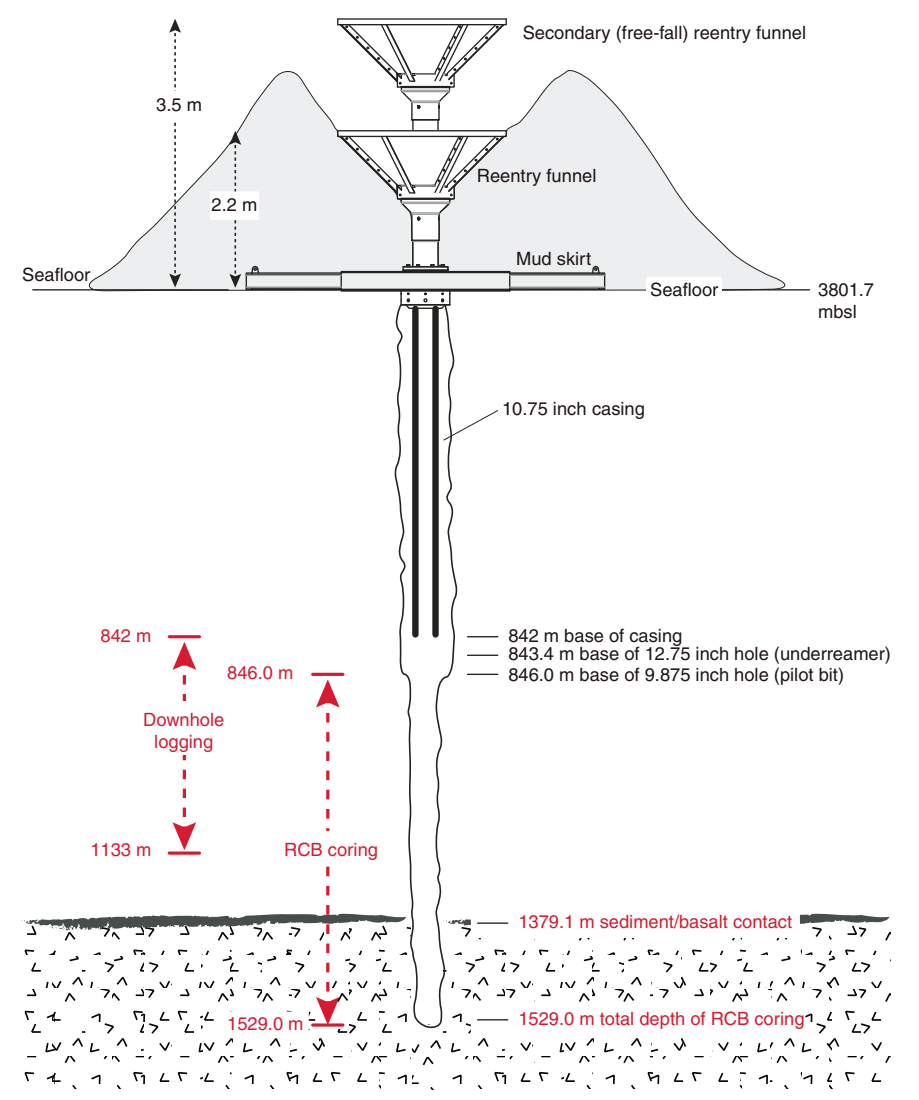


Figure F10. Reentry system and casing, Hole U1502B.

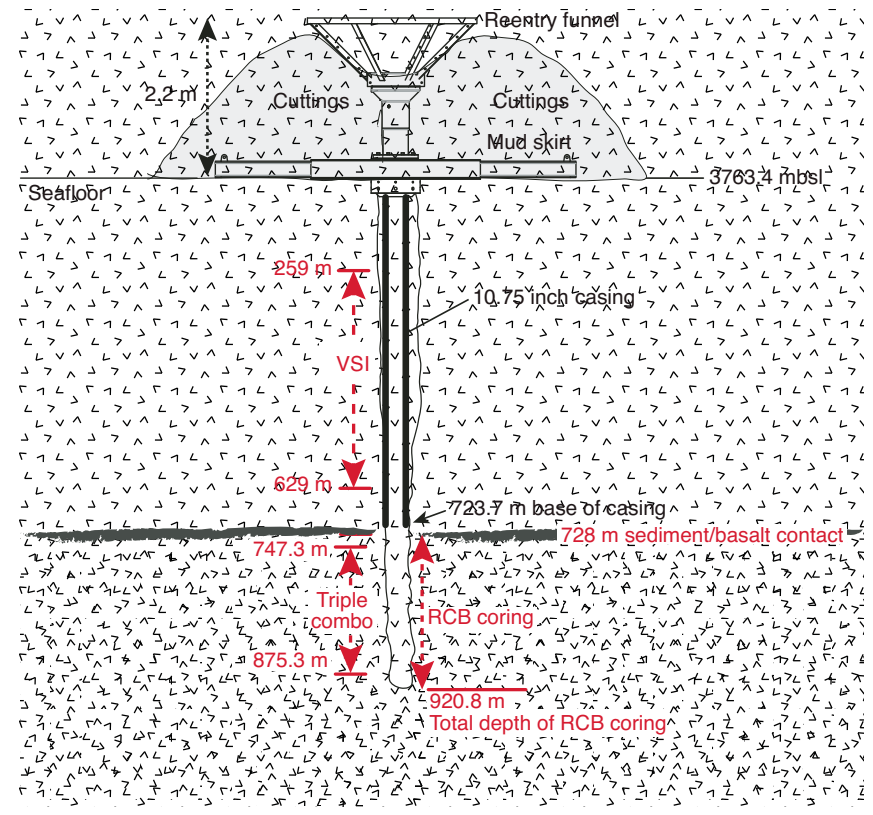

cus our operations time to achieve our highest priority basement objectives. The implemented operations are shown in Figures F6 and F7.

At Site U1499, the pilot (first) hole (U1499A) consisted of $\mathrm{APC} / \mathrm{XCB}$ coring until refusal. In the pilot hole (U1500A) at Site U1500, we washed down without coring in the limits of safety approval and the requirements to identify appropriate locations for setting casing in the subsequent hole. We also decided not to collect downhole log data in either of these pilot holes, partly due to poor borehole conditions that we thought would not yield good data and partly to focus more time on the deeper core and log objectives.

For the primary, deep-penetrating, cased holes at each of the first two sites, we set as much casing as possible $(651 \mathrm{~m}$ in Hole U1499B and $842 \mathrm{~m}$ in Hole U1500B) to keep the upper part of the hole in stable condition for drilling and to enhance our ability to clean cuttings out of such deep holes. Casing was drilled into the seafloor to total depth as a single step at each location to minimize hole disturbance and save time. We then drilled and cored using the RCB system below the casing until we reached the basement (Hole $\mathrm{U} 1500 \mathrm{~B}$ ) or until hole conditions prevented further coring (Hole U1499B). We collected downhole logging data in the deep penetration hole at each site.

At Site U1501, the pilot hole (U1501C) consisted of APC/XCB coring until refusal. From the findings, we concluded that in this location the formation might be stable enough to continue with the deeper RCB Hole U1501D to $\sim 600 \mathrm{~m}$ without casing. Logging was therefore not done in Hole U1501C. Hole U1501D was drilled without coring to a slightly shallower depth than Hole U1501C and then RCB cored to the bottom of the hole. Logging was then executed. This approach saved considerable operational time. We drilled in Hole U1502A to $375 \mathrm{~m}$ without coring and then cored with the RCB system to identify a proper casing point. Casing was then drilled in
Figure F11. Reentry system and casing, Hole U1503A.

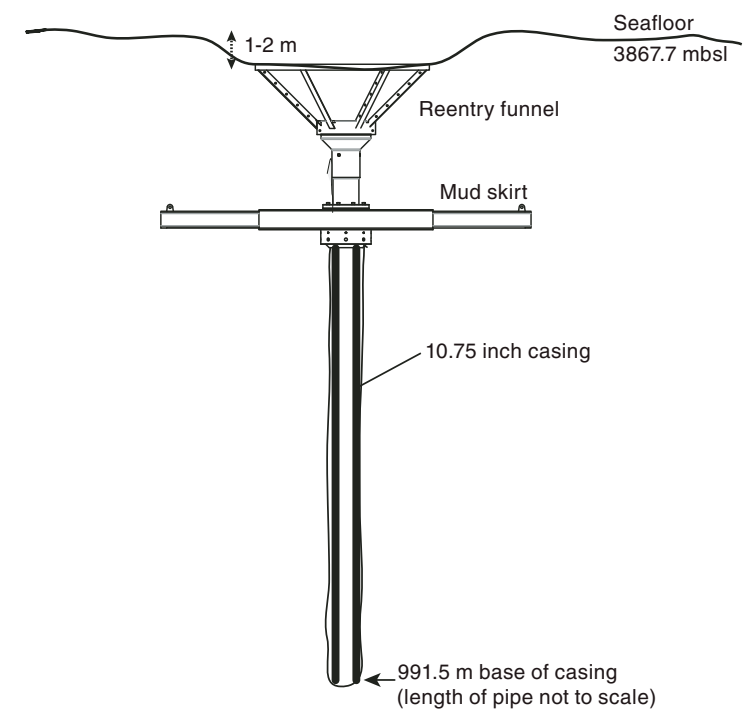

$\sim 1640 \mathrm{~m}$ sediment/basalt contact

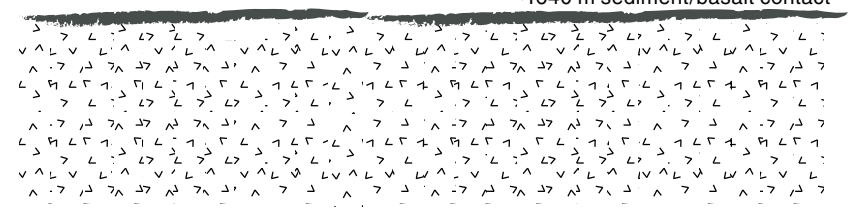

Hole U1502B to the desired depth, followed by RCB coring to target. Single-run logging (triple combo) was then executed in the open hole below casing with VSI check shots in both open hole and casing. At Site U1503, we initially drilled in Hole U1503A without coring to a planned casing depth $(990 \mathrm{~m})$ estimated on the basis of drilling data from Site U1500 ( $20 \mathrm{~km}$ away) and seismic correlation between the two sites. A free-fall reentry system was deployed, and casing was subsequently installed in the already established Hole U1503A with the assistance of the underreamer and mud motor (Figure F12). This approach turned out to be very efficient and saved much time. Unfortunately, mechanical problems at the rig floor (lower clutch of the drawworks) prevented us from further pursuing the site.

With an operational limit of deploying a maximum of $3400 \mathrm{~m}$ of drill string for the remainder of Expedition 368, no deep sites requiring casing could be pursued. Site U1504 had a primary basement target below only $\sim 120 \mathrm{~m}$ of sediment cover. Hole U1504A was RCB cored to $\sim 150 \mathrm{~m}$. Hole U1504B was drilled without coring to $\sim 90 \mathrm{~m}$ and continued with RCB coring to $200 \mathrm{~m}$. No logging was pursued.

Four holes were cored and/or drilled at Site U1505. Hole U1505C was cored with the APC as deep as possible, further cored with the half-length advanced piston corer (HLAPC) system until refusal, extended by $\mathrm{XCB}$ coring until the maximum length of the drill string was reached at $480 \mathrm{~m}$, and then logged. Hole U1505D was cored with the APC to $180 \mathrm{~m}$. 
Figure F12. (A) Reentry system on the seafloor after free fall and (B) inspection of reentry cone after casing installation, Hole U1503A. The hole remains as a legacy hole for future occupation.

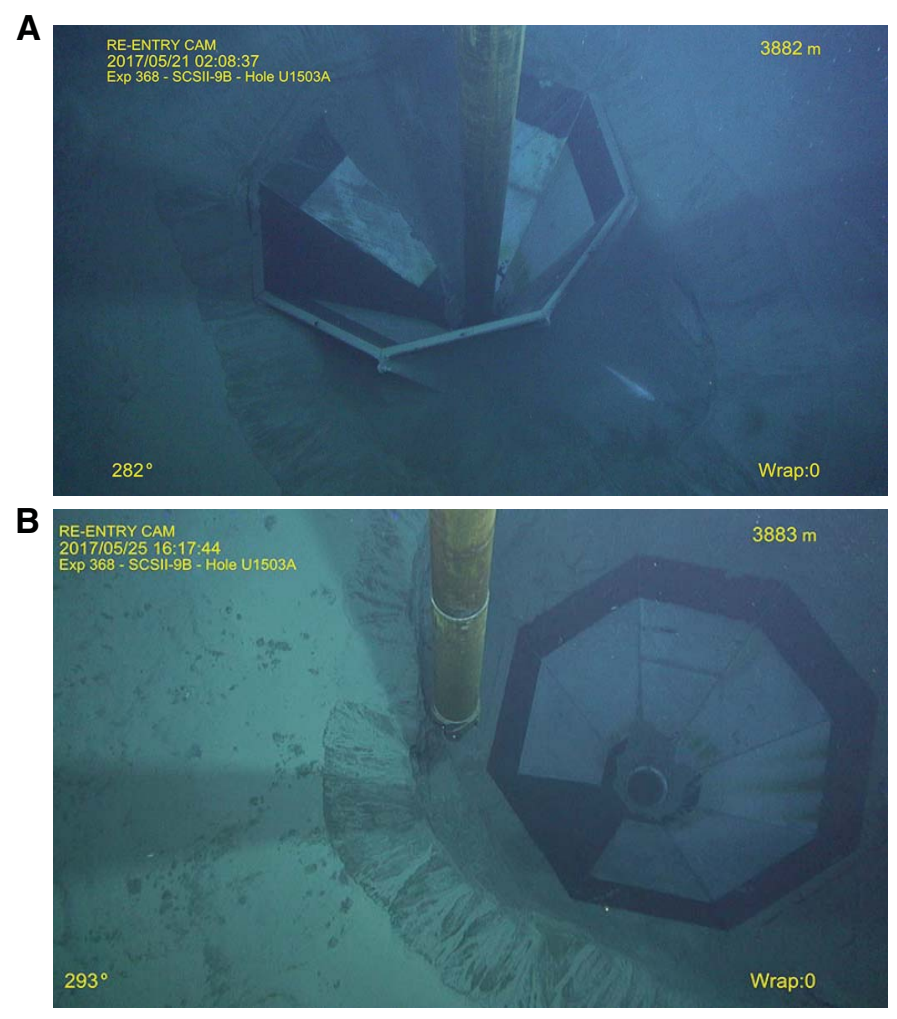

\section{Site summaries}

\section{Site U1499}

Site U1499 is located on basement Ridge A in the SCS COT zone $\sim 60 \mathrm{~km}$ seaward and southeast of the OMH. The goal of drilling here was to core through the sediment to sample the basement rocks and thus determine basement age and lithology, which would provide a test of different possible models for the processes and rheology controlling the extension and ultimate breakup of the continent. Ridge A was expected to have basement of either upper continental crust, lower continental crust, or exhumed mantle rocks. Coring and drilling also constrain the postrift history by determining the age, water depth, and subsidence rates of the overlying sedimentary packages.

We conducted operations in two holes at Site U1499 (proposed Site SCSII-14A; Sun et al., 2016b) (Table T1). Hole U1499A is located at $18^{\circ} 24.5698^{\prime} \mathrm{N}, 115^{\circ} 51.5881^{\prime} \mathrm{E}$ in a water depth of $3760.2 \mathrm{~m}$. In Hole U1499A, APC/XCB coring penetrated from the seafloor to $659.2 \mathrm{~m}$ and recovered $417.05 \mathrm{~m}$ (63\%). Hole U1499B is located at $18^{\circ} 24.5705^{\prime} \mathrm{N}, 115^{\circ} 51.5990^{\prime} \mathrm{E}$ in a water depth of $3758.1 \mathrm{~m}$. We installed casing in Hole U1499B to $651 \mathrm{~m}$ followed by RCB coring that penetrated from 655.0 to $1081.8 \mathrm{~m}$ and recovered $150.64 \mathrm{~m}$ (35\%). Coring terminated in gravel before deteriorating drilling conditions prevented further penetration; no crystalline basement was encountered. Despite challenging conditions in the lowermost part of Hole U1499B, two successful wireline logging runs were conducted from 652 to $1020 \mathrm{~m}$.

\section{Lithostratigraphy}

The cored sediment at Site U1499 is divided into nine lithostratigraphic units (Figure F13). Lithostratigraphic Unit I is a 48.85 $\mathrm{m}$ thick middle-upper Pleistocene sequence of dark greenish gray bioclast-rich clay with thin clayey silt and sand interbeds. Finingupward silt and fine sand intervals are abundant and interpreted as turbidite sequences. Four thin $(2-7 \mathrm{~cm})$ ash layers were identified in Unit I; none were observed in the deeper units. Unit II $(48.85-100.04 \mathrm{~m})$ is a $51.19 \mathrm{~m}$ thick middle-upper Pleistocene sequence of interbedded greenish gray clay-rich calcareous ooze and dark greenish gray nannofossil-rich clay. Synsedimentary deformational structures such as folds, microfaults, and inclined beds are well developed in the sediment of this unit, which is interpreted as a slump deposit. This unit is underlain by Unit III (Pliocene-middle Pleistocene), which is divided into Subunits IIIA (100.04-181.80 m) and IIIB (181.80-333.65 m). The $233.61 \mathrm{~m}$ of Unit III is dominated by dark greenish gray clay with thick to very thick clayey silt and calcareous sand interlaminations. Subunit IIIA contains clayey silt layers that are thick laminations $(<1 \mathrm{~cm})$, whereas Subunit IIIB has abundant thin beds $(2-5 \mathrm{~cm})$ of clayey silt and an overall increase in nannofossil and foraminifer content. Unit IV $(333.65-404.90 \mathrm{~m})$ is a $71.25 \mathrm{~m}$ thick sequence of upper Miocene-Pliocene dark greenish gray silty sand with clay interbeds. Recovery is very low throughout this unit, but the recovered intervals and physical property data suggest that the sections with no recovery may contain unconsolidated to weakly consolidated sand.

Unit V (404.90-469.45 m) is a $64.55 \mathrm{~m}$ thick sequence of upper Miocene dark greenish gray clay with mostly thin $(<5 \mathrm{~cm})$ clayey silt and foraminifer sand interbeds. Drilling disturbance in the form of biscuiting increases significantly in this unit. Similar to Unit IV, recovery in Unit VI (469.45-618.30 m) is very low. The recovered intervals in this unit include upper Miocene dark greenish gray silty sand with clay interbeds. Unit VII $(618.30-761.70 \mathrm{~m})$ is mainly composed of upper Miocene dark greenish gray to dark gray sandstone and claystone with siltstone interbeds. Lithification increases sharply downhole from the top of this unit, although sections with no recovery are inferred to be nonlithified sand. Unit VIII (761.70-929.02 m) comprises a $167.32 \mathrm{~m}$ thick interval of upper Oligocene-Miocene reddish brown to reddish gray claystone and clay-rich chalk. Based on the abundance of calcareous material, this unit is divided into two subunits. Subunit VIIIA (761.70-892.10 m) contains lower-upper Miocene dark reddish brown claystone with siltstone and foraminifer sandstone interbeds, whereas Subunit VIIIB (892.10-929.02 m) is composed of upper Oligocene-lower Miocene reddish brown to reddish gray clay-rich nannofossil chalk and clay-rich chalk. In the lowest part of Subunit VIIIB, abundant brownish black iron-manganese nodules occur in reddish brown nannofossil-rich claystone.

Unit IX $(929.02-1081.80 \mathrm{~m})$ is readily distinguished from the overlying units by containing Oligocene (and pre-Oligocene?) sandstone, claystone, matrix-supported breccia, and gravel. This unit is $152.78 \mathrm{~m}$ thick and comprises three subunits. Subunit IXA $(929.02-933.28 \mathrm{~m})$ is defined by dark brown and greenish gray sandstone and breccia. Subunit IXB (933.28-933.35 m) is defined by dark gray matrix-supported breccia in Core 367-U1499B-30R. Subunit IXC (933.35-1081.80 m) contains gray to dark gray gravel with silty sand intervals. The cores in Subunit IXC are completely fragmented and were recovered as pebbles and cobbles. In general, 
Table T1. Expedition 367 hole summary. $-=$ no data. Download table in CSV format.

\begin{tabular}{|c|c|c|c|c|c|c|c|c|c|c|c|}
\hline Hole & $\begin{array}{l}\text { Proposed } \\
\text { site }\end{array}$ & Location & $\begin{array}{c}\text { Water } \\
\text { depth (m) }\end{array}$ & $\begin{array}{c}\text { Total } \\
\text { penetration } \\
\text { (m) }\end{array}$ & $\begin{array}{l}\text { Cored } \\
\text { interval } \\
(\mathrm{m})\end{array}$ & $\begin{array}{c}\text { Drilled } \\
\text { interval } \\
\text { without } \\
\text { coring } \\
\text { (m) }\end{array}$ & $\begin{array}{l}\text { Core } \\
\text { recovery } \\
(\mathrm{m})\end{array}$ & $\begin{array}{l}\text { Core } \\
\text { recovery } \\
(\%)\end{array}$ & $\begin{array}{c}\text { Time on } \\
\text { hole } \\
\text { (days) }\end{array}$ & $\begin{array}{l}\text { Cores } \\
(N)\end{array}$ & $\begin{array}{l}\text { Depth of } \\
10.75 \text { inch } \\
\text { casing } \\
\text { (m) }\end{array}$ \\
\hline U1499A & SCSII-14A & $\begin{array}{l}18^{\circ} 24.5698^{\prime} \mathrm{N} \\
115^{\circ} 51.5881^{\prime} \mathrm{E}\end{array}$ & 3760.2 & 659.2 & 659.2 & 0.0 & 417.05 & 63 & 7.2 & 71 & - \\
\hline \multirow[t]{2}{*}{ U1499B } & & $\begin{array}{l}18^{\circ} 24.5705^{\prime} \mathrm{N} \\
115^{\circ} 51.5990^{\prime} \mathrm{E}\end{array}$ & 3758.1 & 1081.8 & 426.8 & 655.0 & 150.64 & 35 & 14.9 & 44 & 651 \\
\hline & & \multicolumn{2}{|c|}{ Site U1499 totals: } & 1741.0 & 1086.0 & 655.0 & 567.69 & 52 & 22.1 & 115 & - \\
\hline U1500A & SCSII-8B & $\begin{array}{l}18^{\circ} 18.2762^{\prime} \mathrm{N} \\
116^{\circ} 13.1916^{\prime} \mathrm{E}\end{array}$ & 3801.7 & 854.6 & 329.8 & 524.8 & 93.55 & 28 & 5.5 & 34 & - \\
\hline \multirow[t]{3}{*}{ U1500B } & & $\begin{array}{l}18^{\circ} 18.2707^{\prime} \mathrm{N} \\
116^{\circ} 13.1951^{\prime} \mathrm{E}\end{array}$ & 3801.7 & 1529.0 & 683.0 & 846.0 & 278.80 & 41 & 24.8 & 81 & 842 \\
\hline & & \multicolumn{2}{|c|}{ Site U1500 totals: } & 2383.6 & 1012.8 & 1370.8 & 372.35 & 37 & 30.3 & 115 & - \\
\hline & & \multicolumn{2}{|c|}{ Expedition 367 totals: } & 4124.6 & 2098.8 & 2025.8 & 940.04 & 45 & 52.4 & 230 & 1493 \\
\hline
\end{tabular}

the pebbles and cobbles are recycled sedimentary rocks (such as sandstone) that contain a variety of individual lithic components including igneous, sedimentary, and metamorphic clasts. Although the matrix that likely surrounded these cobbles and pebbles was not recovered, we infer that the matrix is poorly consolidated and washed away by the drilling process. Based on this description, Subunit IXC may represent synrift or prerift sediments.

\section{Structural geology}

The tilting of sedimentary beds and deformation structures observed at Site U1499 are limited to lithostratigraphic Units II, VII, VIII, and IX. The folds, faults, and tilted beds observed in Unit II are related to two slump events that reworked older sediment between younger Units I and III. Tilted beds and faults with slickensides were observed in Units VII and VIII. These faults are linked to compaction processes of the clays, and the tilted beds are associated with sandy layers. Unit IX is divided into three subunits. In Subunit IXA, tilted beds and a downhole increase in clast size, angularity, and proportion of clasts were observed. The matrix-supported breccia of Subunit IXB exhibits no clear deformation structure or tilted sedimentary bedding. Some of the sandstone and breccia clasts in Subunit IXC exhibit veins and fractures. These clasts were transported before sedimentation; therefore, their veins and fractures must have originated in a previous tectonic event.

\section{Biostratigraphy}

All core catcher samples at Site U1499 were analyzed for calcareous nannofossil and foraminiferal content, and additional samples were taken from the split-core sections when necessary to refine the ages. Preservation of microfossils varies from poor to very good, and total abundance varies from barren to abundant. Although samples exhibit some degree of reworking, 28 biostratigraphic datums are recognized, revealing that we recovered an apparently continuous succession of the Oligocene to the Pleistocene spanning nannofossil Zones NP25-NN21 and foraminifer Zones M4/M3 to Subzone PT1b. The Pleistocene/Pliocene boundary is located between Cores 367-U1499A-20X and 27X, the Pliocene/Miocene boundary is located between Cores $31 \mathrm{X}$ and $43 \mathrm{X}$, and the Miocene/Oligocene boundary is in Section 367-U1499A-30R-2. Sedimentation rates varied from $\sim 80 \mathrm{~mm} / \mathrm{ky}$ in the late Miocene-early Pliocene and $\sim 50 \mathrm{~mm} / \mathrm{ky}$ in the early Pliocene-early Pleistocene to $\sim 130 \mathrm{~mm} / \mathrm{ky}$ in the middle-late Pleistocene. Extremely low sedimentation rates $(\sim 8 \mathrm{~mm} / \mathrm{ky})$ occurred in the early-middle Miocene during deposition of Unit VIII. Subunit IXA contains early-late Oligocene microfossils (calcareous nannofossils and foraminifers) with different preservation and abundance, probably influenced by transported and reworked materials.

\section{Paleomagnetism}

Paleomagnetic analysis was conducted on both archive-half sections and discrete samples from the working half. The archive-half sections were measured with the pass-through superconducting rock magnetometer (SRM) with demagnetization steps at 5, 15, and $25 \mathrm{mT}$. The discrete samples were subjected to alternating field (AF) and thermal demagnetization, and remanence was measured on the spinner magnetometer. We adopted a combination of stepwise AF and thermal demagnetization steps to fully demagnetize the discrete samples and obtain the characteristic remanent magnetization (ChRM).

Variations in natural remanent magnetization (NRM) intensity are well correlated to observable changes in lithology and magnetic susceptibility; for example, the low NRM intensity at $\sim 60 \mathrm{~m}$ (Core 367-U1499A-7H) agrees with the carbonate-rich slump in which magnetic susceptibility values are also low. Drilling-induced remanence was identified and removed in most core sections at AF treatments of $15 \mathrm{mT}$. In addition, magnetic mineral variations were observed from the demagnetization behavior. From Core 367U1499B-12R downhole, the drilling overprint becomes stronger and hard to remove with the relatively low AF steps used on the archive-half sections, whereas AF treatments up to $200 \mathrm{mT}$ and temperatures up to $675^{\circ} \mathrm{C}$ could not fully demagnetize the discrete samples. These characteristics confirm the presence of higher coercivity magnetic minerals, such as hematite, compared with the predominant magnetite and/or titanomagnetite. But further rock magnetic property measurements should be conducted in a shorebased laboratory in order to better understand the compositions.

We constructed the magnetostratigraphy of Holes U1499A and U1499B based on the interpretation of the raw paleomagnetic data that show stable and clear demagnetization behaviors. Declinations from 0 to $162 \mathrm{~m}$ have been corrected by the Icefield MI-5 core orientation tool and therefore could help accurately define magnetic reversals. Otherwise, only inclinations are used for polarity interpretations. After correlating the magnetostratigraphy to the standard geomagnetic timescale, we confidently identified the boundary between the Brunhes and Matuyama Chrons at $\sim 110 \mathrm{~m}$. We thus conclude that the middle/early Pleistocene boundary $(0.78 \mathrm{Ma})$ is at 
Figure F13. Lithostratigraphic summary, Site U1499.

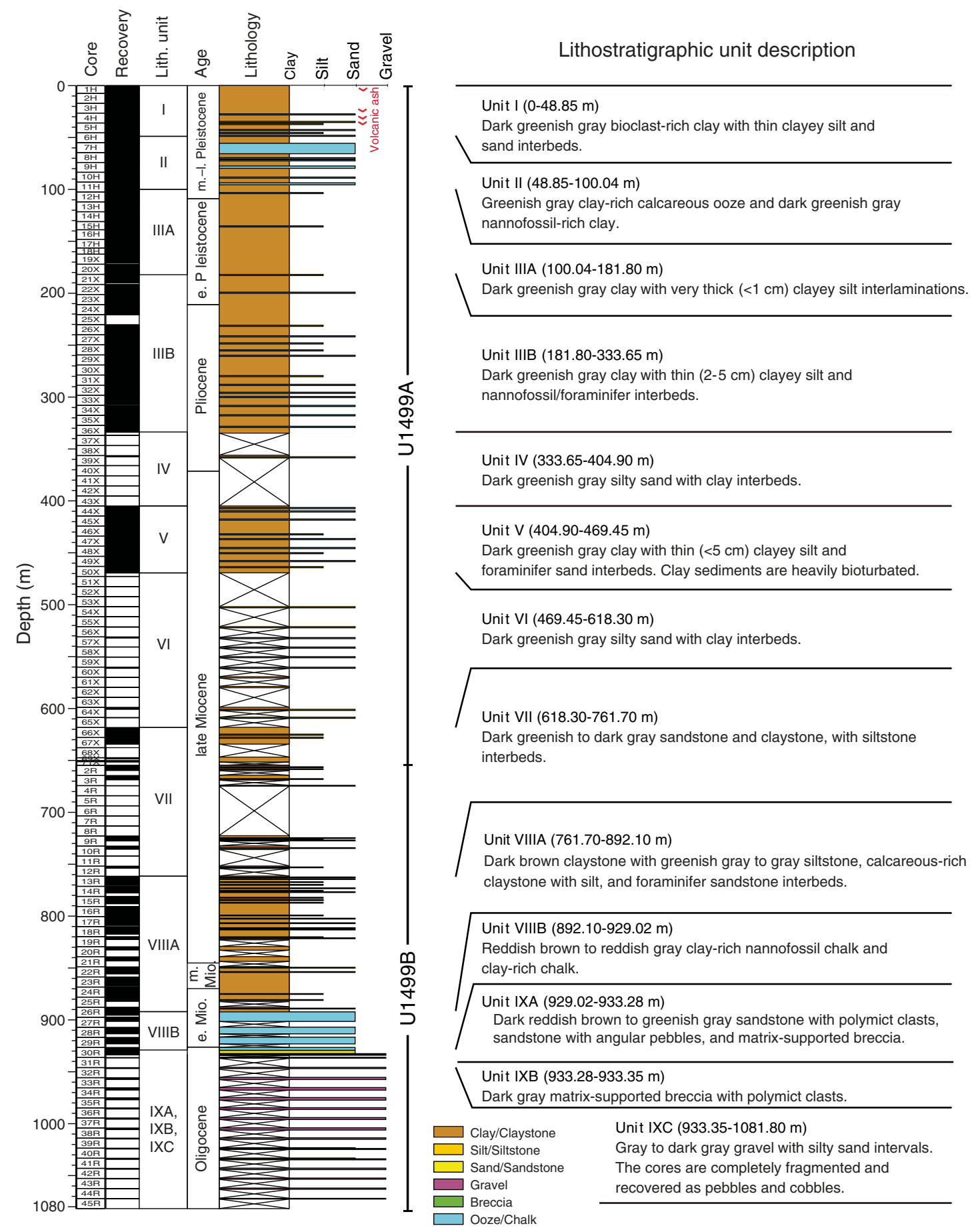

$\sim 110 \mathrm{~m}$, the early Pleistocene/late Pliocene boundary is at $\sim 220 \mathrm{~m}$, the late/early Pliocene (3.6 Ma) boundary is at $\sim 260 \mathrm{~m}$, and early Pliocene/late Miocene boundary (5.33 Ma) is at $\sim 370 \mathrm{~m}$.

\section{Geochemistry}

Geochemical analyses were conducted for headspace gas safety monitoring; quantification of sediment $\mathrm{CaCO}_{3}$, organic carbon, and nitrogen content; and interstitial water characterization. Calcium carbonate contents vary between 0.4 and $82 \mathrm{wt} \%$, with higher values of $>20 \mathrm{wt} \%$ corresponding to intervals of nannofossil/foraminifer ooze or chalk. Total organic carbon (TOC) contents mostly range from $\sim 0$ to $\sim 1.0 \mathrm{wt} \%$. TOC decreases gradually downhole from 1.0 to $0.3 \mathrm{wt} \%$ in the uppermost $110 \mathrm{~m}$ corresponding to the base of the sulfate reduction zone, reflecting active degradation of sedimentary organic matter. The TOC to total nitrogen molar ratio (TOC/TN) is mostly $<8$, indicating that TOC is derived dominantly from a marine source.

Hydrocarbon monitoring shows headspace gas consistently approaching zero throughout the site. Relatively higher methane contents of approximately tens to 6000 ppmv occur across the $\sim 100-$ 
$250 \mathrm{~m}$ interval, just below the sulfate reduction zone. The overall low methane content indicates limited microbial methanogenesis likely caused by low TOC contents (<0.3 wt\%) deeper than $110 \mathrm{~m}$.

We obtained 58 interstitial water samples from Hole U1499A. The inorganic geochemistry of interstitial water is controlled by the remineralization of organic matter and carbonate and clay diagenesis. The sediment rapidly becomes suboxic, as indicated by a Mn peak of $\sim 120 \mu \mathrm{M}$ at $\sim 6 \mathrm{~m}$. Sulfate reduction coupled with sedimentary organic matter degradation occurs to $\sim 110 \mathrm{~m}$, with nearcomplete depletion to $257 \mathrm{~m}$ before increasing slowly to $16.9 \mathrm{mM}$ at the bottom of Hole U1499A. The interval of near-complete sulfate consumption is also marked by pronounced high $\mathrm{Ba}$ concentrations $>50 \mu \mathrm{M}$, suggesting the dissolution of barite $\left(\mathrm{BaSO}_{4}\right)$. The peak alkalinity and steady increase in $\mathrm{NH}_{4}{ }^{+}$and $\mathrm{Br}^{-}$in the upper $110 \mathrm{~m}$ are consistent with progressive remineralization of sedimentary organic matter. The gradual decrease in $\mathrm{Ca}^{2+}$ shallower than $80 \mathrm{~m}$ suggests active authigenic carbonate precipitation triggered by sulfate reduction. A subsequent downhole increase in $\mathrm{Ca}^{2+}$ and $\mathrm{Sr}^{2+}$ is likely caused by biogenic carbonate dissolution and recrystallization. Nearly parallel downhole decreases in $\mathrm{Mg}^{2+}$ and $\mathrm{K}^{+}$are mostly driven by clay mineral cation exchange and/or clay mineral authigenesis. The lower $\mathrm{Cl}^{-}$and $\mathrm{Na}^{+}$concentrations compared to those of seawater at the bottom of Hole U1499A are mostly driven by the smectite-illite transformation. Elevated Si concentrations of 700$820 \mu \mathrm{M}$ from the seafloor to $45 \mathrm{~m}$ suggest active dissolution of biogenic silica.

\section{Petrophysics}

At Site U1499, measurements of P-wave velocity, bulk density, magnetic susceptibility, and natural gamma radiation (NGR) were made on whole-round cores, and additional measurements were made on split cores and discrete samples, including thermal conductivity; caliper $P$-wave velocity on the $P$-wave caliper (PWC); porosity; and bulk, dry, and grain density. In general, bulk density, $P$ wave velocity, and thermal conductivity increase with depth, whereas porosity decreases with depth as a result of compaction and lithification. However, some properties, such as NGR or magnetic susceptibility, show local variations related to the specific lithology. The soft sediment in the upper $100 \mathrm{~m}$ shows rapid compaction with depth, marked by a decrease in porosity and increase in bulk density and thermal conductivity. Four thin volcanic ash layers in the uppermost $50 \mathrm{~m}$ are marked by peaks in magnetic susceptibility. The mass transport deposit (48.85-100.04 m) displays low magnetic susceptibility and low NGR, reflecting the high carbonate content of the calcareous ooze. Below these layers downhole to $\sim 890$ m, physical properties show small variations; bulk density, $P$ wave velocity, and thermal conductivity gradually increase, whereas porosity decreases with depth. The NGR and magnetic susceptibility data in this interval do not show much variation. From 830 to $930 \mathrm{~m}$, we observed a general decrease in magnetic susceptibility and NGR where density increases slightly and $P$-wave velocity increases significantly from 2200 to $2900 \mathrm{~m} / \mathrm{s}$. These variations are associated with a significant increase in the carbonate content in the Subunit VIIIB chalks. The cobbles and pebbles in the deepest part (930-1080 m) show large variations in NGR, bulk density, and Pwave velocity and very low magnetic susceptibility.

\section{Downhole measurements}

Two downhole logging tool strings were run in Hole U1499B, a modified triple combo (sonic velocity, NGR, bulk density, resistivity, and caliper) tool string and the FMS-sonic tool string (FMS resistiv- ity images and calipers, as well as NGR). We added the velocity tool to the first tool string because sonic velocities were needed for an accurate prediction of basement depth for the subsequent Site U1500 and to better constrain core-log-seismic correlation. We also did not know if hole conditions would allow a second logging run. Although stable borehole conditions in Hole U1499B allowed the second FMS logging run, we did not attempt a check shot due to time constraints and concerns about hole stability. Borehole conditions from the bottom of the casing at $\sim 651 \mathrm{~m}$ to the bottom of Hole $\mathrm{U} 1499 \mathrm{~B}$ at $\sim 1020 \mathrm{~m}$ were generally good, with measured diameters from $\sim 10$ to 16 inches. Washout zones were observed from 670 to $710 \mathrm{~m}$, which corresponds to an interval of very low core recovery, as well as from 830 to $920 \mathrm{~m}$, affecting quality of the log data in these intervals. Log and core data are generally in good agreement. Downhole logging provided information in zones of poor core recovery in Hole U1499B. The log data from 726 to 739 m exhibits high NGR and low bulk density and $P$-wave velocity, whereas the data from 820 to $840 \mathrm{~m}$ is characterized by a sharp increase in bulk density, a slight increase in $P$-wave velocity, and an abrupt decrease in NGR compared to average values above and below these depths. The Subunit VIIIB chalks ( 890-930 m) display a sharp decrease in NGR and an increase in bulk density and $P$-wave velocity with depth, as well as only small variations in resistivity. Deeper than 930 $\mathrm{m}$, bulk density, $P$-wave velocity, and resistivity show large variability, in part because of the presence of cobbles and pebbles. The quality of the acquired FMS images is strongly influenced by variations in hole diameter; they generally show alternating smooth and patchy textures with contrasting resistivity marking horizontal to slightly tilted bedding downhole to $930 \mathrm{~m}$. The deepest layers of sandstones, breccias, and gravels show highly variable and oblique textures on the FMS images, possibly reflecting the varied orientation of the gravel clasts or the presence of faults and fractures in the gravel or the matrix. In general, the velocity measured with the sonic velocity logging tool match the PWC measurements taken with the caliper on the split cores. Six in situ formation temperature measurements were made in Hole U1499A and give a geothermal gradient of $93^{\circ} \mathrm{C} / \mathrm{km}$. The estimated heat flow is $110 \mathrm{~mW} / \mathrm{m}^{2}$, a value in agreement with the general heat flow of the area.

\section{Correlation to seismic data}

We used downhole log data and physical property measurements on cores and samples as well as other available data to correlate Site U1499 data with the available seismic reflection profiles. We also used the Site U1499 density and sonic velocity data to create synthetic seismograms that provided additional constraints on the correlation. Log sonic velocities and PWC velocities are in very good agreement, except for the deepest breccias and gravels (deeper than $\sim 930 \mathrm{~m}$ ) where measurement on individual pebbles leads to an overestimate of the velocity in the formation. For seismic correlation, we used the PWC and density data from moisture and density (MAD) and gamma ray attenuation (GRA) density data from Hole U1499A (0-655 m), whereas below that depth we used the downhole logging velocity and density data. We used a constant velocity of $2100 \mathrm{~m} / \mathrm{s}$ in the low-recovery zones (333-406 and 531-561 m), interpreted to be sandy layers, based on the downhole logging velocity values measured at greater depth. The comparison of the time-depth relationship (TDR) obtained for Site U1499 to those for Sites 1148, U1431, and U1433 shows substantial agreement, except for the Site 1148 TDR, which shows higher velocities in the deeper layers. The comparison among the seismic reflectors and the variations in physical properties and lithology characteristics using the 
computed Site U1499 TDR shows a good correlation between the main upper reflectors and the poor-recovery sandy intervals. However, the main physical property changes related to the top of the deep gravel layer do not correlate to the reflector observed at $\sim 5.9 \mathrm{~s}$ in the seismic profile.

\section{Site U1500}

Site U1500 is located on basement Ridge B and is the most seaward site that Expedition 367 drilled in the SCS COT zone. Ridge B is located $\sim 80 \mathrm{~km}$ seaward of the $\mathrm{OMH}$ and $\sim 20 \mathrm{~km}$ seaward of Ridge A, where Site U1499 was drilled. The goal of drilling here was to sample and log the lowermost sediment and underlying basement rocks to determine basement age and lithology of the COT or embryonic oceanic crust, thus providing a test of different possible models for the processes and rheology controlling the breakup of the continent. Ridge B was expected to have basement of either upper continental crust, lower continental crust, mantle rocks, or oceanic crust. The coring and logging would also constrain the history of the region after rifting by determining the age, water depth, and subsidence rates of the overlying sedimentary packages.

We conducted operations in two holes at Site U1500 (proposed Site SCSII-8B; Sun et al., 2016b) (Table T1). Hole U1500A is located at $18^{\circ} 18.2762^{\prime} \mathrm{N}, 116^{\circ} 13.1916^{\prime} \mathrm{E}$ in a water depth of $3801.7 \mathrm{~m}$. In Hole U1500A, we drilled without coring from the seafloor to 378.2 $\mathrm{m}$ and then cored with the RCB system from 378.2 to $494.6 \mathrm{~m}$ and recovered $26.5 \mathrm{~m}$ (23\%). Thereafter, we drilled without coring from 494.6 to $641.2 \mathrm{~m}$ and cored with the RCB system from 641.2 to 854.6 $\mathrm{m}$ and recovered $67.2 \mathrm{~m}(31 \%)$.

Hole U1500B is located at $18^{\circ} 18.2707^{\prime} \mathrm{N}, 116^{\circ} 13.1951^{\prime} \mathrm{E}$ in a water depth of $3801.7 \mathrm{~m}$. After installing casing, we continuously cored the sediment sequence from 846.0 to $1379.1 \mathrm{~m}$ (533.1 m cored; $164.7 \mathrm{~m}$ recovered; $31 \%$ ) and then continuously cored $149.9 \mathrm{~m}$ into the underlying basalt from 1379.1 to $1529.0 \mathrm{~m}$ (114.92 m recovered; $77 \%)$. This made Hole U1500B the eighth deepest hole that the R/V JOIDES Resolution has drilled in ODP/Integrated Ocean Drilling Program/IODP history. Three downhole logging strings were run in Hole U1500B from 842 to $1133 \mathrm{~m}$.

\section{Lithostratigraphy}

The cored sediment at Site U1500 is divided into eight lithostratigraphic units (Figure F14). The uppermost $378.2 \mathrm{~m}$ of sediment was drilled without coring. Lithostratigraphic Unit I (378.2$410.0 \mathrm{~m}$ ) is a $31.8 \mathrm{~m}$ thick upper Miocene sequence of greenish gray heavily bioturbated clay with silt and sandy silt interbeds. Some of the clay intervals are nannofossil rich. Structure in the clay is mostly massive, but parallel laminations occur in the silt and sandy silt interbeds. Unit II (410.0-494.6 m) is an upper Miocene sequence of interbedded dark greenish gray clay and silt. Recovery was very low for this unit ( $\sim 8 \%)$, which may indicate a change in lithology (e.g., increased abundance of nonlithified sands). This unit is underlain by another interval drilled without coring (494.6-641.2 m).

Unit III (641.2-892.4 $\mathrm{m}$ ) is defined by upper Miocene interbedded claystone, siltstone, and sandstone. Many of the siltstone and sandstone intervals are organized into a variety of massive and stratified beds that include sedimentary structures such as parallel laminations, cross-stratification, and contorted strata. There are also several massive beds of sandstone that contain pebble-sized mud clasts. The well-organized coarser intervals fine upward into more massive claystone intervals and are interpreted as turbidite sequences. Several of the stratified beds are composed of foraminifer tests.
Unit IV (892.4-1233.3 m) also had very low recovery (15\%). This unit is composed of lower upper Miocene very dark greenish gray to dark gray sandstone with dark brown to very dark gray claystone and siltstone intervals. Many of the intervals described in this unit contain interlaminations of silt or sand in a prevailing claystone lithology. Similar to Unit III, sedimentary structures in many of the sandstone and siltstone intervals are interpreted as turbidites. The claystone in some of the cores shows a distinctive color banding, which was observed as a pattern of alternating reddish brown, dark greenish gray, and brownish gray. The color banding appears to be associated with fining-upward grain sizes and varying levels of bioturbation. Sandstone intervals in this unit contain high percentages of K-feldspar, quartz, plagioclase, and mica minerals that may have been sourced from granitic rocks exposed along the southern margin of China.

Unit V (lower middle Miocene) is divided into Subunits VA (1233.30-1272.10 m) and VB (1272.10-1310.98 m) based on the abundance of calcareous material. Subunit VA consists of dark reddish brown, dark greenish gray, and dusky red homogeneous massive claystone with few sandstone and siltstone interbeds $(3-12 \mathrm{~cm}$ thick). Subunit VB consists of dark reddish brown, reddish brown, and greenish gray intervals of claystone, nannofossil-rich claystone, claystone with biogenic carbonate, and clay-rich chalk. The greenish gray color banding in Subunits VA and VB is interpreted as diagenetic alteration.

Unit VI (1310.98-1370.33 m) is composed of Oligocene dark greenish gray massive silty claystone with biogenic carbonate and dark gray sandstone. Unit VII (1370.33-1379.10 m) comprises a thin (30 cm thick) Oligocene dusky red claystone. The lowermost 2 $\mathrm{cm}$ of this unit has a greenish gray color that marks a sharp horizontal contact with the igneous rocks below in Unit VIII. The basalt in Unit VIII (1379.10-1529.0 m), which is Oligocene or preOligocene in age, contains some fractures that are filled with welllithified claystone. The claystone contains authigenic carbonate, siliciclastic components, and rare nannofossils. The basalt intervals are sparsely intercalated with dusky red claystone, with the basalt/sediment contacts often associated with chilled glassy margins. Some claystone intervals in the basalt unit show evidence of dolomitization in thin section.

\section{Igneous petrology}

In Hole U1500B, we cored 149.9 m of igneous rocks below the sedimentary section and recovered a total of $114.92 \mathrm{~m}$ of basalt. The aphanitic to porphyritic basalts are nonvesicular to moderately vesicular and glassy to hypocrystalline, with the latter ranging from cryptocrystalline to fine grained, making up an aphyric to highly olivine-plagioclase phyric texture (microstructure). These basalts contain numerous $2-5 \mathrm{~cm}$ thick baked/chilled contacts and chilled margins, many of the latter with preserved fresh glass, as well as occasional hyaloclastites showing brecciated glass fragments mixed with sediment. The basalts comprise Unit VIII and are divided into igneous lithologic Subunits $1 \mathrm{a}$ and $1 \mathrm{~b}$ according to flow boundaries to distinguish an upper massive lava flow sequence (27.28 m thick) from a lower, predominantly pillow lava flow succession $(122.62 \mathrm{~m}$ thick) with subordinate thin $(<6 \mathrm{~m})$ interbedded lobate, sheet, and massive lava flows. The pillow lobes are well preserved and are separated by chilled, glassy margins (identifying upper and lower chilled margins of individual pillows where possible) and also claystone. Plagioclase phenocrysts are found throughout these basalts, with olivine being an occasional phenocryst. Modal abundances of olivine and plagioclase phenocrysts increase downhole, reaching a 
Figure F14. Lithostratigraphic summary, Site U1500.

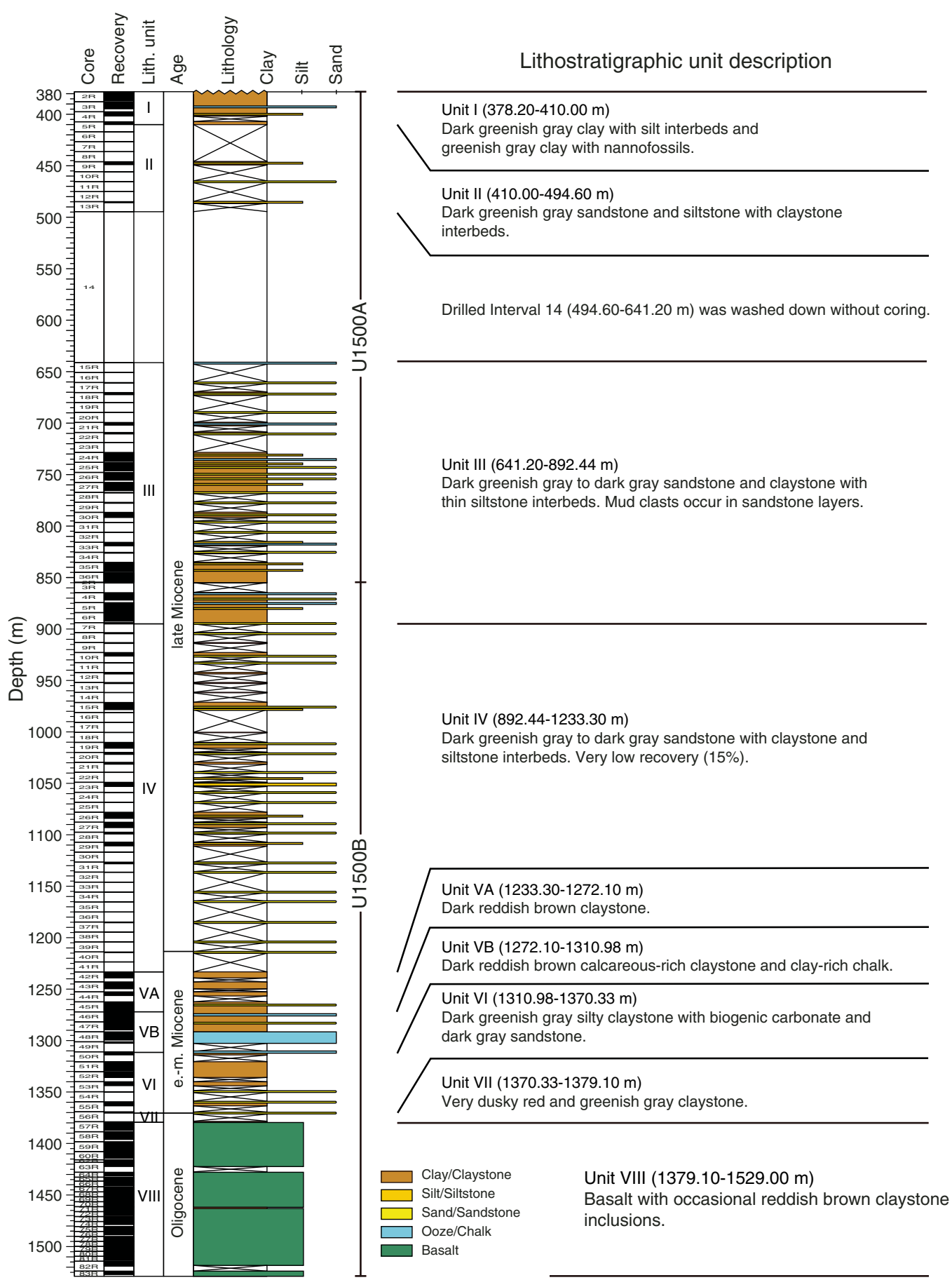

peak between 1420 and 1470 mbsf. Veins occur throughout Unit VIII and are predominantly filled with carbonates and Fe (hydr)oxides, chlorites, zeolites, and silica, as well as sediment. Veins usually show a sharp contact with the host basalt and are either polycrystalline or massive. Claystone is a ubiquitous phase in many carbonate-rich veins, especially in pillow lava flows, and is usually found as very fine aggregates in carbonate veins or as centimeterthick veins with no preserved textures or structures. Red to greenred halos usually surround the carbonate veins, which are related to the background alteration of interstitial glass, olivine, and occasion- ally plagioclase and clinopyroxene. Alteration of these basalts remains slight overall, as evidenced by the minimal alteration of interstitial glass as well as the good preservation of plagioclase. Alteration intensity, however, does increase downhole.

\section{Structural geology}

Tilted sedimentary bedding and deformation structures were observed in all lithostratigraphic units. Faults, tilted beds, folds, and mud clasts observed in Units I, II, and III are likely related to gravity-controlled deposition (e.g., debris flows, slumps, slides, etc.). 
Unit IV has low recovery and exhibits only a few tilted beds and compaction faults. A total of 47 centimeter-scale faults were measured in the claystone of Units V, VI, and VII. Many of these faults have slickensides and are likely related to clay compaction during lithification. Open fractures and veins are identified in the sparsely to highly plagioclase phyric basalts of Unit VIII. There are no preferred orientations of these structures. Most of the veins are filled by carbonate minerals, Fe oxides, sediment, and secondary minerals. Veins are often haloed by Fe oxide alteration. Vein connectivity is variable; single veins, branched veins, and vein networks were observed. There is no mineral-preferred orientation. Although the seismic profile across Site U1500 shows dipping reflectors in the basalt, we did not observe any clear paleohorizontal or dipping features in these lavas.

\section{Biostratigraphy}

All core catcher samples were analyzed for calcareous nannofossil and foraminifer contents. Additional samples were taken from the split-core sections when necessary to refine the ages between core catcher samples. Preservation of microfossils varies from poor to good. Overgrown and abundant broken fragments are common in the sediment sequences. The total abundance varies from barren to abundant, and most samples exhibit some degree of reworking.

Although recovery is low and $\sim 50 \%$ of the samples are barren, the succession is apparently continuous and is tentatively assigned a late Oligocene-Miocene age. The late/middle Miocene boundary (11.6 Ma) can be placed between Samples 367-U1500B-37R-1, 40$41 \mathrm{~cm}$, and 44R-CC. Both calcareous nannofossils and planktonic foraminifers indicate an early Miocene to late Oligocene succession in Cores 46R through 56R.

In the calcareous sandstone (Section 56R-1), just above the basalt, some younger species, such as Praeorbulina circularis (middle Miocene), Globigerinoides subquadratus, and Orbulina suturalis, are found together with the typical late Oligocene-early Miocene planktonic foraminiferal species (Catapsydrax dissimilis). In the same sample, the nannofossil content is represented by long-range species and cannot give a precise age. However, two samples from the veins and intrapillow fill of the basalts in Unit VIII contain poorly preserved calcareous nannofossils that indicate an Oligocene age. The resolution of the age discrepancy in Core 56R requires further postexpedition studies.

\section{Geochemistry}

At Site U1500, measurements of organic and inorganic carbon and nitrogen were conducted on one sample per sedimentary core that had relative high recovery, and headspace gas measurements were taken for all sediment cores. In addition, four basalt samples were analyzed for concentrations of major elements and several trace elements using inductively coupled plasma-atomic emission spectroscopy (ICP-AES). Headspace gas values do not exceed 15 ppmv and are mostly below the quantification limit. Carbonate contents are dominated by biogenic carbonate and vary between $<1$ and $40 \mathrm{wt} \%$, with higher values corresponding to the calcareous-rich lithostratigraphic units. TOC and TOC/TN are low, averaging 0.14 $\mathrm{wt} \%$ and 4.6, respectively. ICP-AES analyses of basalts from Site U1500 indicate subalkaline mid-ocean-ridge basalt (MORB)-like compositions.

\section{Paleomagnetism}

We conducted AF demagnetization of archive-half sections and $\mathrm{AF}$ and thermal demagnetization of representative discrete samples from both sedimentary successions and the igneous rocks. For the sedimentary samples, AF demagnetization could effectively removed the drilling-induced overprint. The polarity interpretation results based on inclination data from the sedimentary long core and discrete samples are in agreement, which supports our current preliminary polarity patten, but because of discontinuous coring and poor recovery in many cored intervals, we are not able to correlate these results to the standard geomagnetic polarity timescale. The pass-through measurements of the basalts from the archive halves using the SRM effectively removed a low-coercivity component; however, it is not clear if the ChRM or primary magnetization has been reached, partly due to the unavoidable magnetic contamination and partly due to the destructive feature and thus limited AF treatment levels (up to $25 \mathrm{mT}$ ).Within a single igneous subunit, basalts sometimes show both positive and negative inclinations upon stepwise AF treatments, which makes it hard to assign reliable polarities. The demagnetization behaviors of the discrete basalt samples are of high noise at higher temperatures, which is probably due to the onset of thermo-viscous remanent magnetization especially in a magnetically nonshielded environment. The close association of negative inclinations, changes in magnetic susceptibility, and demagnetization behavior with fractures in the cores points to the possibility of a secondary chemical remanent magnetization (CRM) as the source of the reversed intervals in the basalt.

\section{Petrophysics}

We conducted measurements of GRA bulk density, magnetic susceptibility, and NGR on whole-round cores and additional measurements on split cores and discrete samples, including thermal conductivity, $P$-wave velocity on the PWC, porosity, and bulk, dry, and grain density. In general, bulk density, $P$-wave velocity, and thermal conductivity increase with depth, whereas porosity decreases with depth as a result of compaction and lithification. However, some properties, such as NGR or magnetic susceptibility, show local variations related to the specific lithology. A significant increase in carbonate content in Subunit VB (1272-1311 m) causes a general decrease in NGR and only a slight decrease in magnetic susceptibility. Physical properties change significantly in the basalts of Unit VIII (1379-1529 m). Magnetic susceptibility is two orders of magnitude higher than in the sediment above and varies depending on the degree of alteration. $P$-wave velocity is also much higher, ranging between 4430 and $5710 \mathrm{~m} / \mathrm{s}$, whereas porosity and NGR are very low compared to the sediment above.

\section{Correlation to seismic data}

We used physical property data from cores and samples to correlate Site U1500 data with the available seismic reflection profile. We also used the Site U1500 density and PWC velocity data to create synthetic seismograms that provided additional constraints on the correlation. The TDR obtained for Site U1500 shows substantial agreement with that for Site U1499 and Sites U1431 and U1433; in contrast, the ODP Site 1148 TDR exhibits higher velocities in the deeper layers. The comparison between the seismic reflectors and the variations in physical properties and lithology characteristics using the computed Site U1500 TDR shows good correlation between the high-amplitude seismic reflector at $\sim 6.4 \mathrm{~s}$ two-way traveltime (TWT) and the top of the basalts of Unit VIII.

\section{Downhole measurements}

Three downhole logging tool strings were run in Hole U1500B: a modified triple combo (sonic velocity, NGR, bulk density, resistivity, 
Figure F15. Bathymetry at Site U1501 and location of the site in relation to seismic Lines 15ecLW1 and 15ecLW8.

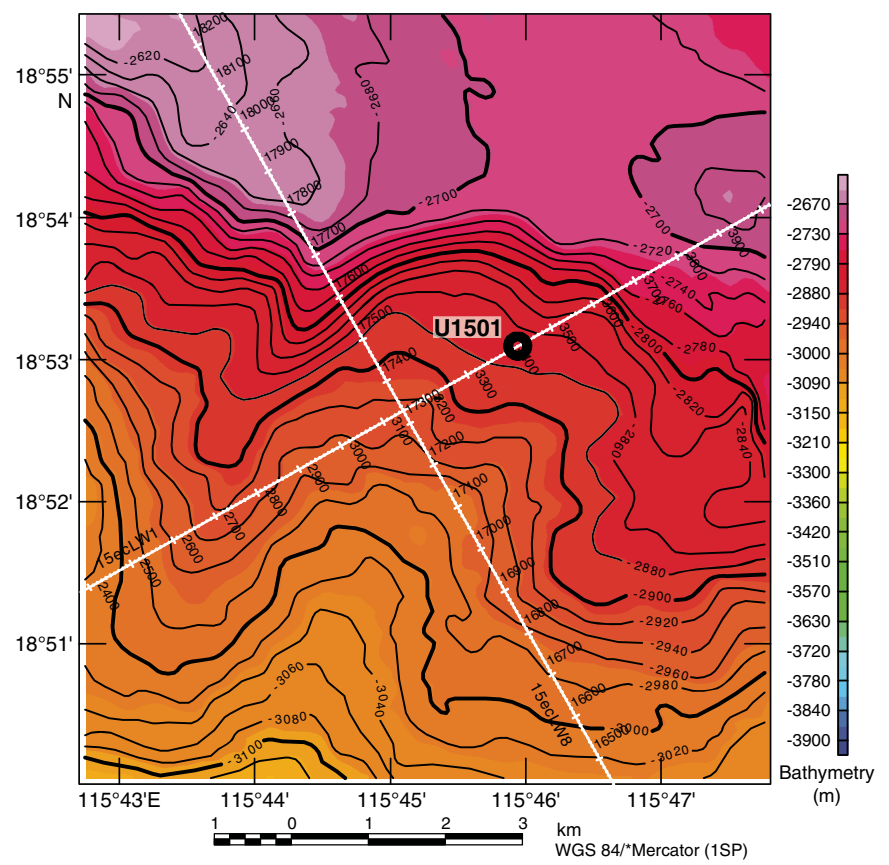

and caliper), the FMS-sonic (FMS resistivity images and calipers, as well as NGR), and the VSI (check shot and NGR). During the first run, the tool string encountered an obstruction at $4946 \mathrm{~m}$ wireline log depth below rig floor (WRF; $1133 \mathrm{~m}$ ), and we were unsuccessful in getting the tool string to pass below this depth. We collected FMS data from $\sim 1044 \mathrm{~m}$ uphole to the bottom of the casing $(842 \mathrm{~m})$. Although the hole had many zones that were significantly enlarged, initial observations of the real-time FMS data indicate that some intervals exhibit relatively good caliper contact and should provide useful resistivity images. A seismic check shot survey with the VSI successfully collected data at one depth in the open hole and at the base of the casing. Because this was the last operation conducted during Expedition 367 and we only had a 1 day transit to Hong Kong, data processing and full evaluation of the log data will be conducted after Expedition 367.

\section{Site U1501}

\section{Background and objectives}

Site U1501 (proposed Site SCSII-41A; $18^{\circ} 53.0923^{\prime} \mathrm{N}$, $115^{\circ} 45.9455^{\prime} \mathrm{E}$ ) (Sun et al., 2016b) in the SCS northern margin (Figure F3) is located on a broad regional basement high $(\mathrm{OMH})$. The $\mathrm{OMH}$ is the most landward of four distinct highs in the COT and is followed seaward by Ridges A, B, and C (Figures F4, F5, F15). Site $\mathrm{U} 1501$ is located at $2845.8 \mathrm{~m}$ below sea level (mbsl). Small rift basins of presumed Paleogene age are located on top of the OMH (Figure F5). These basins can be traced landward into much deeper halfgraben basins that formed during the main phase of crustal extension. The rift basins located on the $\mathrm{OMH}$, therefore, offer options to recover the stratigraphy of these basins by drilling to moderate depths, testing existing stratigraphic interpretations, and extrapolating the findings margin wide. Recovering and characterizing these sequences were key objectives at Site U1501, and the specific goal was to constrain the timing and duration of crustal extension, the tectonic vertical movements during rifting, and the subsequent postrift thermal subsidence. The crystalline basement at Site U1501 is most likely located far below the acoustic basement at $\approx 600 \mathrm{~m}$ and was not an objective for this site.

At $2846 \mathrm{mbsl}$, Site U1501 is one of the few ODP and Integrated Ocean Drilling Program sites in the SCS above the modern CCD of the SCS. Sites U1504 and U1505, also at the OMH, are situated at $<3000 \mathrm{mbsl}$. The younger stratigraphy is therefore also the focus of some secondary scientific objectives related to Neogene environmental development of the SCS and adjacent landmasses of Southeast Asia. Among these secondary objectives are to (1) reconstruct the history of the east Asian monsoon evolution and of deep-water exchanges between the SCS and Pacific Ocean and (2) explore the sedimentary responses to the Cenozoic regional tectonic and environmental development of the Southeast Asia margin.

\section{Operations}

We conducted operations in four holes at Site U1501 (Table T2). In Holes U1501A and U1501B, Core $1 \mathrm{H}$ missed the sediment-water interface and retrieved full core barrels, indicating that the core was shot from below the seafloor. Hole U1501C $\left(18^{\circ} 53.0919^{\prime} \mathrm{N}\right.$, $115^{\circ} 45.9485^{\prime} \mathrm{E} ; 2846 \mathrm{mbsl}$ ) was cored with the APC system from the seafloor to $461.8 \mathrm{~m}$ and recovered $447.8 \mathrm{~m}$ (96.3\%). Hole U1501D $\left(18^{\circ} 53.0929^{\prime} \mathrm{N}, 115^{\circ} 45.9370^{\prime} \mathrm{E}\right.$; $\left.2846 \mathrm{mbsl}\right)$ was drilled without coring from the seafloor to $433.5 \mathrm{~m}$ and then cored with the RCB system to $644.3 \mathrm{~m}$. A total of $78.8 \mathrm{~m}$ of core was recovered (37.4\%). Hole U1501D was logged with the triple combo tool string from 113 to $299.3 \mathrm{~m}$.

\section{Lithostratigraphy}

The sedimentary succession recovered at Site U1501 is composed of clay-rich nannofossil ooze, silty clay, clayey silt, sand, siltstone, sandstone with minor conglomerate, and rare volcanic ash. The succession is divided into three major lithostratigraphic units (I, II, and III) distinguished on the basis of sediment composition, particularly the relative abundance of the calcareous and siliciclastic fractions (Figure F16).

Lithostratigraphic Unit I is a $303 \mathrm{~m}$ thick, Holocene-upper Oligocene succession dominated by clay-rich nannofossil ooze and nannofossil ooze with clay, with minor amounts of nannofossil-rich foraminifer sand or silty sand. A felsic volcanic ash layer occurs in Section 368-U1501A-1H-7, and an ash pod was observed in Section 368-U1501C-3H-1. Unit I is divided into the following subunits:

- Subunit IA (0-25.47 m),

- Subunit IB (25.47-66.17 m),

- Subunit IC (66.30-156.70 m),

- Subunit ID (156.80-191.99 m),

- Subunit IE (191.99-293.09 m), and

- Subunit IF (293.90-303.01 m).

These divisions are based on changes in lithology, particularly the clay to nannofossil ratio, the presence and abundance of foraminifers, and/or physical properties. The lower contact of Unit I is erosional and marked by the emplacement of a poorly sorted sandy layer. At the boundary, marked changes in $P$-wave velocity, NGR, magnetic susceptibility, porosity, MAD, color, carbonate content, and biostratigraphy indicate a small hiatus (Figure F16). Unit I was deposited in a deep-marine environment, and lithologic changes between subunits likely reflect the amount of terrigenous input into a relatively open ocean setting. This input may be delivered as buoyant sediment plumes from shallower shelf environments and rarely by weak (distal) turbidity currents. Soft-sediment deformation in Subunit IB indicates slumping downslope of parts of the sequence. 
Table T2. Expedition 368 hole summary. $-=$ no data. Download table in CSV format.

\begin{tabular}{|c|c|c|c|c|c|c|c|c|c|c|c|}
\hline Hole & $\begin{array}{l}\text { Proposed } \\
\text { site }\end{array}$ & Location & $\begin{array}{c}\text { Water } \\
\text { depth }(m)\end{array}$ & $\begin{array}{c}\text { Total } \\
\text { penetration } \\
(\mathrm{m})\end{array}$ & $\begin{array}{c}\text { Cored } \\
\text { interval } \\
(\mathrm{m})\end{array}$ & $\begin{array}{c}\text { Drilled } \\
\text { interval } \\
\text { without } \\
\text { coring } \\
\text { (m) }\end{array}$ & $\begin{array}{l}\text { Core } \\
\text { recovery } \\
\text { (m) }\end{array}$ & $\begin{array}{c}\text { Core } \\
\text { recovery } \\
(\%)\end{array}$ & $\begin{array}{c}\text { Time on } \\
\text { hole } \\
\text { (days) }\end{array}$ & $\begin{array}{l}\text { Cores } \\
(N)\end{array}$ & $\begin{array}{l}\text { Depth of } \\
10.75 \text { inch } \\
\text { casing }(\mathrm{m})\end{array}$ \\
\hline U1501A & SCSII-41A & $\begin{array}{l}18^{\circ} 53.0922^{\prime} \mathrm{N} \\
115^{\circ} 45.9483^{\prime} \mathrm{E}\end{array}$ & 2857.11 & 9.5 & 9.5 & - & 9.73 & 102.42 & 0.66 & 1 & - \\
\hline U1501B & & $\begin{array}{l}18^{\circ} 53.0922^{\prime} \mathrm{N} \\
115^{\circ} 45.9483^{\prime} \mathrm{E}\end{array}$ & 2852.11 & 9.5 & 9.5 & - & 9.83 & 103.47 & 0.05 & 1 & - \\
\hline U1501C & & $\begin{array}{l}18^{\circ} 53.0919^{\prime} \mathrm{N} \\
115^{\circ} 45.9485^{\prime} \mathrm{E}\end{array}$ & 2845.81 & 461.9 & 461.9 & - & 444.77 & 96.29 & 3.53 & 62 & - \\
\hline U1501D & & $\begin{array}{l}18^{\circ} 53.0929^{\prime} \mathrm{N} \\
115^{\circ} 45.9370^{\prime} \mathrm{E}\end{array}$ & 2845.82 & 644.3 & 210.8 & 433.5 & 78.77 & 37.37 & 5.15 & 26 & - \\
\hline \multicolumn{4}{|c|}{ Site U1501 totals: } & 1125.2 & 691.7 & 433.5 & 523.54 & 49.09 & 9.39 & 90 & - \\
\hline U1502A & SCSII-17A & $\begin{array}{l}18^{\circ} 27.8720^{\prime} \mathrm{N} \\
116^{\circ} 13.8381^{\prime} \mathrm{E}\end{array}$ & 3763.72 & 758.2 & 383.2 & 375.0 & 176.81 & 46.14 & 5.22 & 40 & - \\
\hline U1502B & & $\begin{array}{l}18^{\circ} 27.8798^{\prime} \mathrm{N} \\
116^{\circ} 13.8409^{\prime} \mathrm{E}\end{array}$ & 3763.58 & 920.8 & 193.1 & 727.7 & 131.57 & 68.14 & 14.06 & 36 & 723.7 \\
\hline \multicolumn{4}{|c|}{ Site U1502 totals: } & 1679.0 & 576.3 & 1102.7 & 308.38 & 53.51 & 19.28 & 76 & \\
\hline U1503A & SCSII-9B & $\begin{array}{l}18^{\circ} 8.6300^{\prime} \mathrm{N} \\
116^{\circ} 18.8456^{\prime} \mathrm{E}\end{array}$ & 3867.71 & 995.1 & & 995.1 & 0.00 & 0.00 & 11.88 & 0 & 991.5 \\
\hline \multicolumn{4}{|c|}{ Site U1503 totals: } & 995.1 & & 995.1 & 0 & 0.00 & 11.88 & 0 & - \\
\hline U1504A & SCSII-27A & $\begin{array}{l}18^{\circ} 50.9199^{\prime} \mathrm{N} \\
116^{\circ} 14.5397^{\prime} \mathrm{E}\end{array}$ & 2816.57 & 165.5 & 165.5 & - & 52.93 & 31.98 & 2.17 & 21 & - \\
\hline U1504B & & $\begin{array}{l}18^{\circ} 50.8213^{\prime} \mathrm{N} \\
116^{\circ} 14.5978^{\prime} \mathrm{E}\end{array}$ & 2842.97 & 200 & 111.8 & 88.2 & 21.48 & 19.21 & 3.33 & 19 & - \\
\hline \multicolumn{4}{|c|}{ Site U1504 totals: } & 365.5 & 277.3 & 88.2 & 74.41 & 26.83 & 5.50 & 40 & - \\
\hline U1505A & SCSII-3D & $\begin{array}{l}18^{\circ} 55.0560^{\prime} \mathrm{N} \\
115^{\circ} 51.5369^{\prime} \mathrm{E}\end{array}$ & 2916.57 & 0.3 & 0.3 & - & 0.38 & 126.67 & 0.59 & 1 & - \\
\hline U1505B & & $\begin{array}{l}18^{\circ} 55.0562^{\prime} \mathrm{N} \\
115^{\circ} 51.5370^{\prime} \mathrm{E}\end{array}$ & 2918.57 & 3 & 3 & - & 3.23 & 107.67 & 0.04 & 1 & - \\
\hline U1505C & & $\begin{array}{l}18^{\circ} 55.0570^{\prime} \mathrm{N} \\
115^{\circ} 51.5491^{\prime} \mathrm{E}\end{array}$ & 2917.37 & 480.2 & 480.2 & - & 480.15 & 99.99 & 4.29 & 64 & - \\
\hline U1505D & & $\begin{array}{l}18^{\circ} 55.0458^{\prime} \mathrm{N} \\
115^{\circ} 51.5501^{\prime} \mathrm{E}\end{array}$ & 2917.00 & 184.5 & 184.5 & - & 191.43 & 103.76 & 1.2 & 20 & - \\
\hline \multicolumn{4}{|c|}{$\begin{array}{l}\text { Site U1505 totals: } \\
\text { Expedition } 368 \text { totals: }\end{array}$} & 4832.8 & 2213.3 & 2619.5 & 1601.08 & 138.24 & 52.17 & 292 & - \\
\hline
\end{tabular}

Lithostratigraphic Unit II is $296 \mathrm{~m}$ thick and late Oligocene to late Eocene in age. The unit consists of variable amounts of clay, silt, and sand with minor nannofossil-rich clay, nannofossil ooze, and silt with organic matter. Gravel-sized grains occur, including shell fragments and glauconite, as well as carbonate and pyrite concretions. Unit II is divided into six subunits:

- Subunit IIA (303.01-385.26 m),

- Subunit IIB (388.80-452.69 m),

- Subunit IIC (452.60-482.33 m),

- Subunit IID (491.00-519.80 m),

- Subunit IIE (529.30-548.64 m), and

- Subunit IIF (548.64-598.91 m).

The uppermost two subunits define a fining-upward succession of glauconite-sand dominated to siltstone and clay overlain by clay with nannofossils. Subunits IIC and IE are dominated by sandstone with calcite; Subunit IID has more fine-grained, organic-rich lithologies; and Subunit IIF is similar to Subunit IIB but has more coarse-grained sediment and distinctive weak red and reddish gray intervals in the green glauconite-bearing sands. Coarse sand- to pebble-sized shell fragments are common in Unit II, and coral fragments were occasionally observed in the upper part of the unit. Glauconite and quartz minerals dominate the siliciclastic grain component. Diagenetic pyrite is common. Unit II most likely represents a gradual change upward from shallow-water (outer shelf or upper continental slope) to deep-water (lower slope) depositional environments. The Unit II/III boundary was not recovered but is marked by an abrupt change in magnetic susceptibility, NGR, and $P$-wave velocity. A change in the apparent dip of strata from near horizontal in Unit II to $\sim 20^{\circ}$ in Unit III suggests that the contact is unconformable.

Lithostratigraphic Unit III (598.91 $\mathrm{m}$ to the bottom of the hole) is well lithified and composed of poorly sorted, feldspar-rich sandstone interbedded with moderately to well-sorted, medium- to finegrained sandstone and, rarely, siltstone and poorly sorted conglomerate. The age is unknown because no fossils were recognized. Unit III is divided into two subunits: IIIA (598.91-629.79 m) and IIIB $(629.79-643.56 \mathrm{~m})$. Subunit IIIA is composed of coarse-grained heterolithic sandstone, sandstone with calcite clasts, and minor conglomerate and siltstone. Pebble- to cobble-sized clasts include felsic intrusive and volcanic rocks, sedimentary rocks, metamorphic rocks, and rare gabbro. Subunit IIIB consists of sandstone and minor sandstone with organic matter. Subunit IIIB is finer grained than Subunit IIIA and has finely laminated intervals. We speculate that Unit III was formed in continental to littoral environments with a provenance not far from the site.

\section{Structural geology}

Unit I shows predominantly horizontal to subhorizontal bedding with local soft-sediment deformation structures such as slump folds. Unit I is devoid of any structures related to tectonic deformation, apart from some rare normal faults with minor offsets.

Unit II is characterized by subhorizontal to gently dipping bedding. Steep dips up to $40^{\circ}$ are locally observed in close relation to 
Figure F16. Lithostratigraphic, biostratigraphic, and magnetostratigraphic summary, Site U1501.

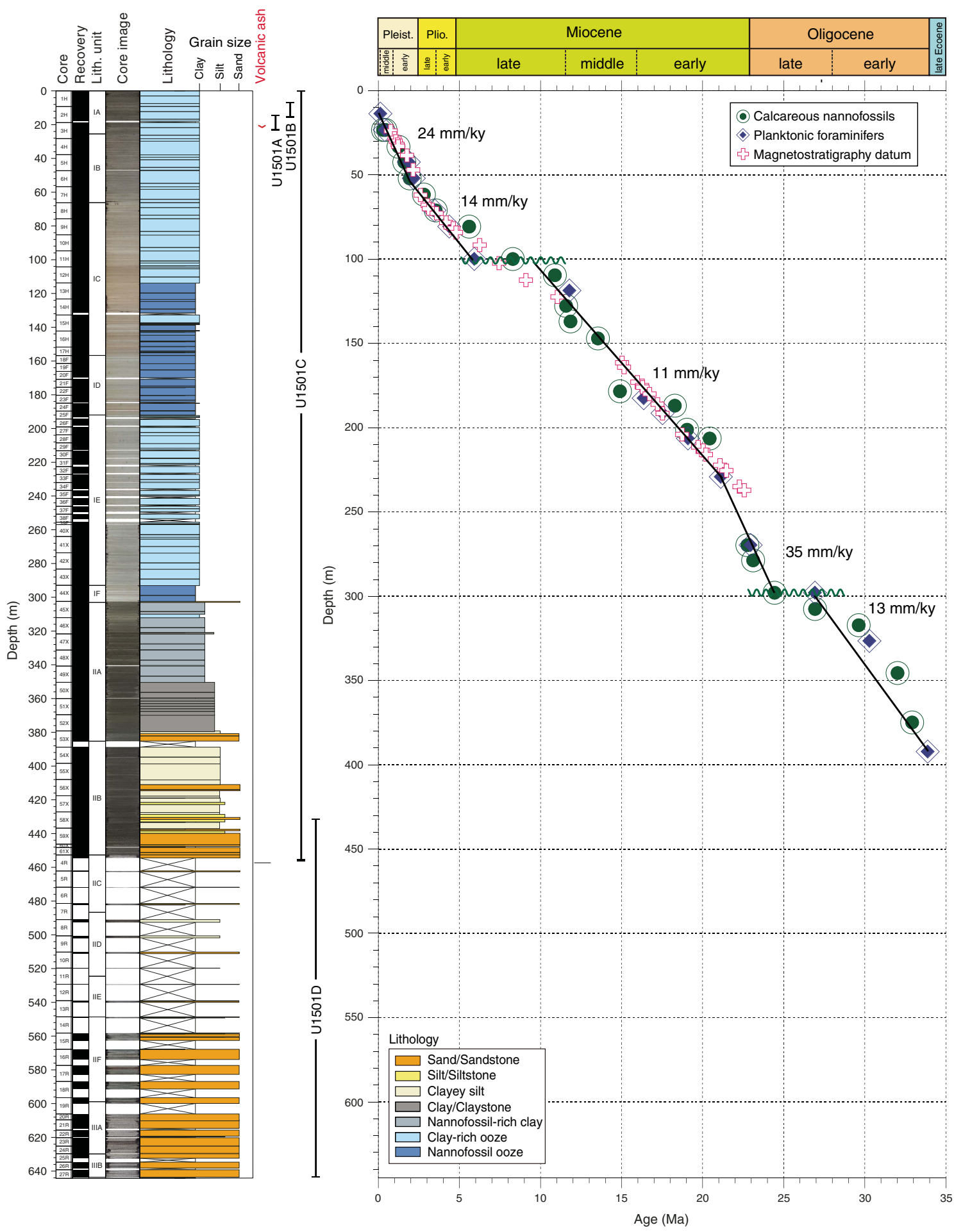

parallel lamination and are therefore interpreted as cross-laminae. In contrast to Unit I, deformation structures were observed in Unit II, although their occurrence is rather heterogeneously distributed. Planar to irregular millimeter-scale normal faults and joints were observed in Subunit IIA, typically with offsets ranging from 0.1 to $0.5 \mathrm{~cm}$ and apparent dips of $10^{\circ}-40^{\circ}$. Striations and slickensides were documented locally where the surfaces of such structures are exposed. Deformation in the underlying Subunits IIC-IIF is essen- tially characterized by randomly distributed occurrence of single to branched uniform calcite and quartz veins. Recognition of deformational structures was difficult due to drilling disturbance throughout this unit.

The acoustic basement marks the top of Unit III. This unit shows a weak tilting of stratified beds expressed in apparent dips on split core surfaces up to $\sim 20^{\circ}$. Again, deformation structures remain scarce and heterogeneously distributed in Unit III. The recognized 
structures consist of veins, fractures, and local microfaults associated with cataclastic fault gouge.

In conclusion, despite the various tilting of reflectors $\left(\sim 5^{\circ}\right)$ and the vicinity of extensional structures observed on seismic profiles, only weak evidence of bedding tilting and/or deformation structures were observed at this site, possibly due to the nature of the sediments.

\section{Biostratigraphy}

All core catcher samples at Site U1501 were analyzed for calcareous nannofossils, diatoms, and foraminifers, with select core catchers examined for ostracods. Additional samples were taken from the split working-half sections when necessary to refine the ages between core catcher samples. Preservation of calcareous microfossils varies from good in Unit I (Cores 368-U1501A-1H, 368-U1501B-1H, and 368-U1501C-1H through $44 \mathrm{X}$ ) to poor in Units II and III (Cores 368-U1501C-45X through 62X and 368U1501D-2R through 5R). Planktonic foraminifers and calcareous nannofossils are abundant in Unit I, common to rare in Unit II and upper Unit III, and barren in the rest of Unit III (Cores 368U1501D-6R though 27R). Diatoms are few with moderate preservation in Samples 368-U1501A-1H-CC, 368-U1501B-1H-CC, and $368-\mathrm{U} 1501 \mathrm{C}-1 \mathrm{H}-\mathrm{CC}$ and $2 \mathrm{H}-\mathrm{CC}$. The rest of the core catcher samples are barren of diatoms with the exception of Samples 368U1501C-3H-CC, 4H-CC, 33F-CC through 35F-CC, and 46X-CC, in which diatoms are rare with poor preservation. Diatoms are common in burrows found in interval 368-U1501C-35F-1, 118-119 cm, with poor preservation.

Forty biostratigraphic datums were identified in a mostly continuous succession from the Eocene to Holocene, which indicates that Holes U1501C and U1501D penetrated late Eocene or older strata (Figure F16). The Pleistocene/Pliocene boundary ( 2.6 Ma) was placed in Core 368-U1501C-7H, the Pliocene/Miocene boundary ( $5.3 \mathrm{Ma})$ in Core $9 \mathrm{H}$, the Miocene/Oligocene boundary ( 23.0 Ma) between Cores $41 \mathrm{X}$ and $42 \mathrm{X}$, and the Oligocene/Eocene boundary ( 33.9 Ma) between Cores 53X and 54X. Sedimentation rates vary from $\sim 13 \mathrm{~mm} / \mathrm{ky}$ in the early Oligocene, $\sim 11 \mathrm{~mm} / \mathrm{ky}$ in the Miocene, and $\sim 14 \mathrm{~mm} / \mathrm{ky}$ in the Pliocene to $24 \mathrm{~mm} / \mathrm{ky}$ in the Pleistocene. Low sediment accumulation rates $(\sim 3.6 \mathrm{~mm} / \mathrm{ky})$ during the late Eocene through the early Oligocene and in the late Miocene suggest the presence of hiatuses in the sedimentary record during these periods. In contrast, higher sediment accumulation rates (35 $\mathrm{mm} / \mathrm{ky}$ ) exist during the late Oligocene and the early Miocene.

Predominance of shallow-water benthic foraminifer and ostracod assemblages in Cores 368-U1501C-45X through 62X and 368-U1501D-2R through $6 \mathrm{R}$ indicate an upper bathyal to continental shelf paleoenvironment during the Eocene to the early Oligocene. Predominantly abyssal benthic foraminifers and ostracods above Core 368-U1501C-44X indicate that deep-water conditions existed in this part of the SCS since the early Oligocene.

\section{Paleomagnetism}

Paleomagnetic investigations combined measurement and inline AF demagnetization of archive-half sections on the 2G Enterprises SRM with the measurement of discrete samples either AF or thermally demagnetized.

The rock magnetic experiments on six representative samples from Hole U1501C show saturation remanent magnetization $(\mathrm{SIRM}) / \mathrm{X}$ ratios between 12.8 and $14.6 \mathrm{kA} / \mathrm{m}$, indicating the predominance of greigite in Unit I of Hole U1501C, also documented by scanning electron microscopy (SEM) in $2-10 \mu \mathrm{m}$ grains. Thermal demagnetization behaviors show that greigite dominates the
$\mathrm{NRM}$, at least downhole to $83 \mathrm{~m}$. However, the magnetic remanence left above $575^{\circ} \mathrm{C}$ suggests contributions from additional phases such as maghemite (Curie temperature $\left[T_{\mathrm{C}}\right]=\sim 590^{\circ}-675^{\circ} \mathrm{C}$ ) or hematite $\left(T_{\mathrm{C}}=\sim 675^{\circ} \mathrm{C}\right)$.

Both AF and thermal treatments on discrete samples successfully removed the steep low-temperature/coercivity component that represents the drilling overprint. The mean inclination gathered from the high-temperature component is $37.3^{\circ} \pm 6.6^{\circ}$, corresponding to a paleolatitude of $20.8^{\circ} \pm 3.3^{\circ}$ for Unit I (see Lithostratigraphy). Many of the AF-demagnetized discrete samples reveal trends of reversed or normal polarity in the last step of demagnetization $(50 \mathrm{mT})$ and are more difficult to interpret.

The magnetostratigraphy in Holes U1501C and U1501D is based on directions derived from the raw moments measured by the SRM after $25 \mathrm{mT}$ demagnetization step and from the corroborative evidence from discrete samples. Magnetostratigraphy was correlated to the standard timescale and plotted along with the tie points from the microfossil ages from shipboard paleontologists. The paleomagnetic and paleontological age constraints match well over most of the section (Figure F16). A succession of eight normal and five reversed events was recognized in Hole U1501D. However, the lack of biostratigraphic constraints throughout Hole U1501D prevented even a tentative correlation of these events with the standard timescale.

\section{Geochemistry}

Interstitial water samples were obtained downcore to $450 \mathrm{~m}$ (Subunit IIB). In Unit I, variations are mainly the result of diagenetic and microbial processes, and measurements of alkalinity, phosphate, ammonia, and sulfate are in the typical ranges for the region (3.5-5 mM alkalinity, $250-510 \mu \mathrm{M}$ phosphate, $<30 \mu \mathrm{M}$ ammonia, and $<26 \mu \mathrm{M}$ sulfate). However, more atypically (particularly when compared to Expedition 367 Site U1499), the main changes associated with microbial processes are notable only in the uppermost 25 $\mathrm{m}$ in Subunit IA and are typical of organic matter degradation. Deeper than $25 \mathrm{~m}$ in Unit I, changes in interstitial water chemistry appear inhibited until $300 \mathrm{~m}$. These changes may be a consequence of the low organic carbon concentration and high carbonate content ( $~ 50 \mathrm{wt} \%)$ of Unit I. Decreases in sulfate concentrations with depth are more pronounced in Unit II $(>300 \mathrm{~m})$, and in this zone there is heavy pyritization and total sulfur (TS) contents are high, suggesting sulfate reduction has taken place. In the uppermost part of Unit II (300-370 m), chloride, bromide, and sodium are notably lower (chloride $=500 \mathrm{mM}$, cf. $565 \mathrm{mM}$; bromide $=0.75 \mathrm{mM}$, cf. $0.9 \mathrm{mM}$; and sodium $=410 \mathrm{mM}$, cf. $480 \mathrm{mM}$ ). This difference in interstitial water chemical composition is sharp and could result from pressure-isolated units retaining a distinct formation water chemistry or from the migration of chloride-poor formation water.

Headspace gas concentrations are below background laboratory levels in all samples collected from Site U1501 ( $<1 \%$ ppmv). TOC content is typically $<0.5 \mathrm{wt} \%$ in Unit I, except from 0 to $50 \mathrm{~m}$ (Subunit IA). In this interval, a typical black marine mud has a TOC of $\sim 1 \mathrm{wt} \%$. TOC was also typically $<0.5 \mathrm{wt} \%$ in Units II and III, except for a few carbonaceous lithologies: sandstones with plant phytoclasts associated with an ash-rich boghead coal in Unit II (interval 368-U1501D-9R-1, 10-15 cm) and a bitumen-impregnated sandstone in Unit III (interval 27R-1, 12-16 cm). TS content is low in Unit I: $\sim 1 \mathrm{wt} \%$ in Subunit IA and below effective shipboard detection limits of $0.01 \mathrm{wt} \%$ for the rest of Unit I. TS content is higher in Unit II; >1 wt\% in the muddier uppermost part of Unit II and an average of $0.5 \mathrm{wt} \%$ in the sandier, deeper part. 
Elemental compositions primarily reflect geological units and changes in lithology. In Unit I, carbonate contents are high and exceed $50 \mathrm{wt} \%$ in foraminifer-rich intervals (compositionally a limestone). In Units II and III, carbonate is less common, and the units are predominantly siliciclastic with a distinction between units that are mud rich and feldspathic and sandier units toward the base of the hole. Calcium and strontium are associated with biogenic sediments in Unit I, but in deeper units they covary with aluminum. In the base of Units II and III, sodium and potassium are both high, which is consistent with the dominant presence of feldspathic sediments. The higher aluminum proportion in the uppermost part of Unit II is consistent with the muddier, clay-rich lithologies present here.

\section{Physical properties}

Hole U150A is divided into four units based on the sediment and rock physical properties. Physical properties (PP) Unit 1 (0-300 $\mathrm{m})$ experienced the most evident changes in sediment compaction, which is expressed by increasing bulk density (from 1.4 to 2.0 $\mathrm{g} / \mathrm{cm}^{3}$ ) and $P$-wave velocity (from 1450 to $1930 \mathrm{~m} / \mathrm{s}$ ) and decreasing porosity (from $85 \%$ to $45 \%$ ) with depth. Because PP Unit 1 consists mostly of calcareous ooze, it has relatively low NGR (between 20 and 40 counts/s) and magnetic susceptibility (between $10^{-6}$ and $10^{-5}$ SI). The onset of PP Unit $2(300-450 \mathrm{~m})$ is marked by a rapid increase in NGR and porosity and a rapid decrease in bulk density and $P$-wave velocity, corresponding to a shift to a different lithologic unit with sand, silt, and clay-enriched sediments. In the entire unit, NGR is persistently high (60-80 counts/s), whereas magnetic susceptibility remains as low as $10 \times 10^{-5} \mathrm{SI}$. $P$-wave velocity and bulk density continue to increase with core depth. Most physical properties of PP Unit 3 (450-600 m) have similar values to those of Unit 2, except that $P$-wave velocity is extremely high, up to $4000-6000 \mathrm{~m} / \mathrm{s}$ at some interbeds, and bulk density and porosity increase and decrease to $2.6 \mathrm{~g} / \mathrm{cm}^{3}$ and $2 \%-3 \%$, respectively, at parallel depths. PP Unit 4 $(600-657 \mathrm{~m})$ is distinct from other units due to higher mean NGR (80 counts $/ \mathrm{s})$, bulk density $\left(2.6 \mathrm{~g} / \mathrm{cm}^{3}\right)$, magnetic susceptibility $\left(500 \times 10^{-5} \mathrm{SI}\right)$, and $P$-wave velocity $(4500 \mathrm{~m} / \mathrm{s})$. Throughout the hole $(0-657 \mathrm{~m})$, thermal conductivity values increase from 0.7 to 3.4 $\mathrm{W} /(\mathrm{m} \cdot \mathrm{K})$, most likely as a result of increasing sediment compaction and changes in sediment compositions. $L^{*}$ reflectance values are highly relevant to weight percent carbonate in sediments, which exhibit relatively high L* values between 100 and 160 in the upper 300 $\mathrm{m}$ and thereafter remain as low as 90 .

\section{Downhole measurements}

Wireline logging was conducted in Hole U1501D using a modified triple combo tool string that included the Hostile Environment Natural Gamma Ray Sonde (HNGS), Hostile Environment LithoDensity Sonde (HLDS), High-Resolution Laterolog Array (HRLA), and magnetic susceptibility sonde (MSS). The triple combo run collected good data between $115.1 \mathrm{~m}$ (base of the drill pipe) and $300 \mathrm{~m}$, where it encountered an impenetrable obstruction. Four logging units are defined:

- Logging Unit 1 (base of the drill pipe to $190 \mathrm{~m}$ wireline depth below seafloor [WSF]) is characterized by intervals of large hole diameter and relatively high variability in NGR and magnetic susceptibility.

- Logging Unit 2 (190-260 m WSF) is characterized by a relatively constant hole diameter, relatively homogeneous logs, and submeter-scale layering.
- Logging Unit 3 (260-275 m WSF) again shows a relatively large hole diameter, as well high variability in NGR, density, and resistivity logs.

- Logging Unit 4 (275-300 m WSF) exhibits relatively large values of resistivity and magnetic susceptibility.

The upward log pass indicated a collapsed hole at $\sim 156.3 \mathrm{~m}$ drilling depth below seafloor (DSF) on the caliper curve, and for safety reasons no further attempts to descend deeper than that undergauge spot were made. Because the interval of the collapsed hole was located only $\sim 40 \mathrm{~m}$ below the base of the pipe, the originally planned FMS-sonic tool string was not run. Four in situ formation temperature measurements were made in Hole U1501C, yielding a geothermal gradient of $81.4^{\circ} \mathrm{C} / \mathrm{km}$ and a calculated heat flow of $100.1 \mathrm{~mW} / \mathrm{m}^{2}$. These values are comparable to the relatively high values observed at some ODP and Integrated Ocean Drilling Program sites in this part of the SCS.

\section{Site U1502}

\section{Background and objectives}

Site U1502 (proposed Site SCSII-17A; Sun et al., 2016b) in the SCS northern margin (Figures F3, F17) is located at $3764 \mathrm{mbsl}$ on a prominent basement ridge (A) in the COT (Figure F5). Ridge A is one of four distinct basement highs found across the COT. The $\mathrm{OMH}$ is the most landward of these highs and is followed seaward by the nearly parallel Ridges A, B, and C. A key objective of Expeditions 367 and 368 was to examine the nature of the crust in Ridge A. This ridge is considered to be a pivotal element in the transition from continental to oceanic crust. Hence, the main objective of Site U1502 was to drill through synrift deposits overlying an interpreted shallow-dipping $\left(\sim 20^{\circ}\right)$ fault zone and into the crystalline basement below the fault. Information on the nature and age of the synrift deposits overlying the fault, as well as the nature and age of the overly-

Figure F17. Bathymetry at Site U1502 and location of the site in relation to seismic Lines 15ecLW7, 15ecLW3, and 08ec2660. Note that the site is not at the exact crossing of Lines 15ecILW7 and 15ecILW3.

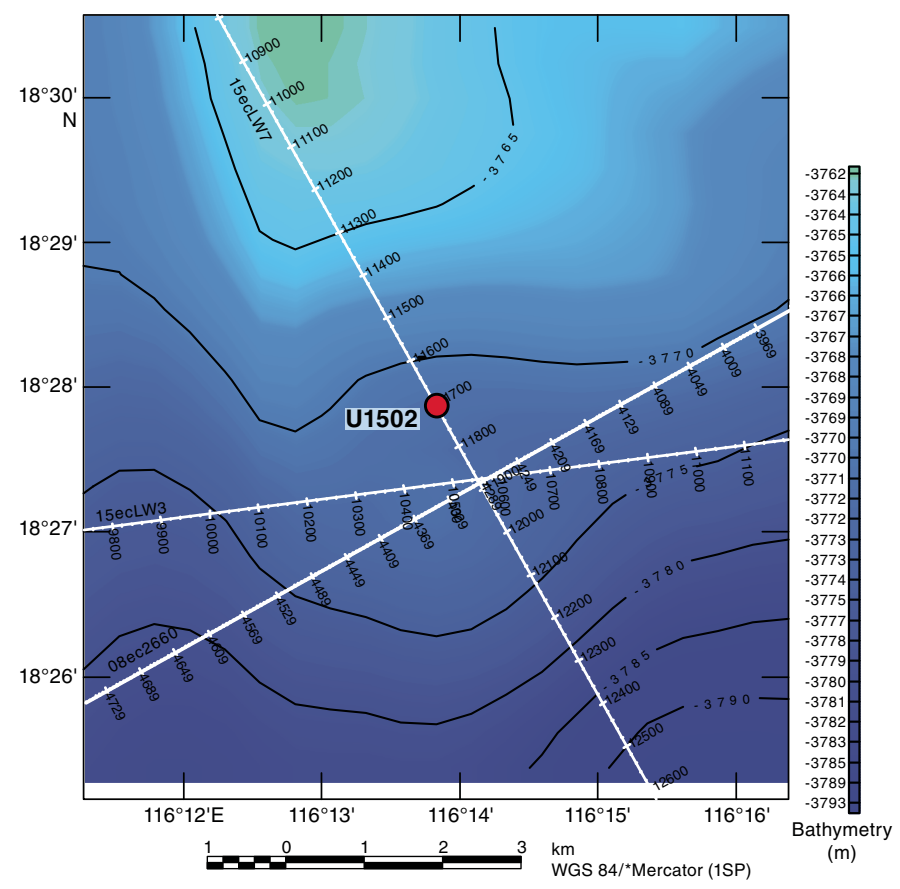


ing sediments and associated seismic unconformities, formed another target with the objective of constraining basin subsidence.

\section{Operations}

We conducted operations in two holes at Site U1502 (Table T2). Hole U1502A is located at $18^{\circ} 27.8720^{\prime} \mathrm{N}, 116^{\circ} 13.8381^{\prime} \mathrm{E}$, at 3763 mbsl. Our operations in Hole U1502A were designed to provide information on formation characteristics and drilling conditions so that we could decide the length of casing to drill into the seafloor in deep-penetration Hole U1502B. Given this purpose and the amount of time to drill the second, deep hole, we did not core continuously in Hole U1502A. Instead, we drilled without coring from the seafloor to $375.0 \mathrm{~m}$ and cored with the RCB system from 375.0 to 758.2 $\mathrm{m}$, recovering $176.81 \mathrm{~m}(46 \%)$. Hole $\mathrm{U} 1502 \mathrm{~B}$ is located at $18^{\circ} 27.8798^{\prime} \mathrm{N}, 116^{\circ} 13.8409^{\prime} \mathrm{E}$, at $3763.6 \mathrm{mbsl}$. In Hole U1502B, we drilled a reentry funnel and $727.7 \mathrm{~m}$ of $10^{3 / 4}$ inch casing into the seafloor; cored with the RCB system through the sediment-basalt transition (727.7-739.16 $\mathrm{m}$ ) and $180 \mathrm{~m}$ into the underlying basalt (739.16-920.95 m), recovering $128 \mathrm{~m}$ (70\%); and collected downhole log data with the triple combo tool string and a check shot with the VSI tool string.

\section{Lithostratigraphy}

The sedimentary succession recovered at Site U1502 extends from the early Oligocene (possibly late Eocene) to the late Miocene. The succession includes four sedimentary units (I and III-V) that are composed of mainly clay, nannofossil-rich clay, biosiliceous-rich clay, limestone, and clast-rich clay and two igneous units (II and VI) that are mainly composed of basalt. The base of the sedimentary succession is a sequence of clay and metasediments (dolomite marble and dolomitic limestone) that possibly forms the contact with a unit of altered basalt (Unit VI) (Figure F18).

Late Miocene to late Oligocene lithostratigraphic Unit I is divided into five subunits. Subunit IA (Hole U1502A = 375.00-486.82 $\mathrm{m}$ ) is composed of dark gray, gray, dark greenish gray, and greenish gray silty clay, clay with nannofossils, and nannofossil-rich clay intercalated with dark grayish brown, grayish brown, and brown clay with nannofossils, with minor dark greenish gray sandy clay with calcite. Subunit IB (Hole U1502A $=490.20-599.57 \mathrm{~m}$ ) is composed of alternating intervals of brown and greenish gray clay, silty clay, and clayey silt. Sandy intervals are rare. Recovery in Subunits IA and IB was very poor, which might be due to the occurrence of thick sand beds that were washed out. Subunit IC (Hole U1502A = $599.57-602.39 \mathrm{~m}$ ) is composed of greenish gray and reddish gray foraminifer-rich clayey siltstone to sandstone with parallel laminations and convolute bedding, with thin layers of pinkish gray foraminiferal chalk. Subunit ID (Hole U1502A $=602.39-724.03 \mathrm{~m}$ ) is mainly composed of alternating greenish and brownish gray and grayish brown clay, silty clay, clayey silt, and clay with silt (Cores 368-U1502A-25R through 32R), but brown colors dominate Cores 33R through 38R. Nannofossils are abundant in the lowermost $\sim 4$ $\mathrm{m}$ of this subunit. Subunit IE (Hole U1502A = 724.03-734.87 m; Hole U1502B; 727.79-727.96 m) is composed of brown nannofossil-rich clay with foraminifers and nannofossil-rich clay with pale green colored halos around fractures. The sediments of Unit I are interpreted as having been deposited in a deep-marine environment. Fining-upward intervals in Subunits IA-IC are interpreted as turbidites.

Unit II is a highly altered greenish gray basalt clast recovered from Hole U1502B at 727.96-728.04 m. The primary mineral phases are replaced by an alteration-mineral assemblage.
Unit III (Hole U1502A = 739.10-739.16 m; Hole U1502B = $728.04-733.82 \mathrm{~m}$ ) is composed of brownish yellow, very hard, poorly sorted breccia. The granule- to pebble-size siliceous clasts consist of alteration minerals (Fe hydroxides) cemented by a matrix of annealed quartz in various grain sizes.

Unit IV (Hole U1502A = 739.16-747.20 m) consists of biosiliceous-rich silty clay. Diatoms, sponge spicules, and radiolarians are abundant in the upper part, but the abundance of both nannofossils and diatoms decreases rapidly downhole from Section 368U1502A-40R-1 to Section 40R-3. Pyrite occurs as centimeter-sized patches and along cracks. The layering in Unit IV is inclined and may be slightly deformed.

Unit V (Hole U1502A $=747.20-749.01 \mathrm{~m}$; Hole U1502B = $733.82-739.16 \mathrm{~m}$ ) is an interval of alternating metasediments (dolomite marble, dolomitic limestone, and clast-rich clay). The dolomite marble is dominated by very fine grained dolomite ( 95\%) with minor amounts of magnetite $(\sim 3 \%)$ and calcite $(\sim 2 \%)$. The annealing texture is equigranular and crossed by fine-grained dark gray bands. The presence of magnetite explains the extraordinarily high magnetic susceptibility of this unit. The gray, fine-grained dolomitic limestone in Hole U1502B is intercalated with well-consolidated, very dark greenish gray clay with $10 \%-15 \%$ igneous clasts. The sediment is partially overprinted with alteration caused by secondary high-temperature processes (e.g., hydrothermal fluid sediment interaction or contact metamorphism).

Unit VI (Hole U1502A = 749.01-750.67 $\mathrm{m}$; Hole U1502B = 739.16-920.95 m) consists of highly altered basaltic breccia, brecciated basalt, pillow basalt, and sheet basalt. The unit is divided into two subunits. Subunit VIA is composed of highly altered basaltic breccia and brecciated basalt with minor sheet basalt, chert, and claystone and very minor pillow basalt. Subunit VIB is dominated by altered pillow basalt and sheet flows and is less brecciated than Subunit VIA.

\section{Igneous petrology}

At Site U1502, we recovered two igneous lithologic units. Unit 1 (lithostratigraphic Unit II) is represented by just three small, aphanitic, fine-grained basalt fragments that contain rare plagioclase phenocrysts (Figure F19). Alteration of Unit 1 is intense, with most of the groundmass replaced by green clay minerals, clinozoisite, zeolites, and Fe (hydr)oxides.

Unit 2 (lithostratigraphic Unit VI) comprises a $182 \mathrm{~m}$ thick sequence of highly altered aphyric to highly plagioclase porphyritic basalts with minor chert (Figure F19). These basalts are divided into two igneous subunits ( $2 \mathrm{a}$ and $2 \mathrm{~b}$ ) based on flow morphology and alteration style: an upper brecciated and fractured massive lava flow sequence (Subunit 2a) and a lower sequence of interbedded pillow flows with lobate and sheet lava flows in which the alteration style is characterized by intense veining (Subunit 2b). Subunit 2a is characterized by highly altered breccia clasts of sparsely to moderately phyric basalt in a matrix of carbonates, epidote, chlorite, Fe (hydr)oxides, quartz, zeolite minerals, and clay minerals. The clasts show an alteration assemblage similar to the matrix, with remnant plagioclase and secondary pyrite. Subunit $2 \mathrm{~b}$ consists of aphyric to highly plagioclase phyric ( $>30 \%)$ basalts with abundant chlorite and sulfides, as well as epidote, clay minerals, carbonates, zeolites, and opaque minerals.

All of Unit 2 has undergone some degree of hydrothermal alteration. This alteration varies from complete replacement of the rock, where the original composition and texture are difficult to determine, to replacement of mineral phases with little change to the tex- 
Figure F18. Lithostratigraphic summary with simplified lithology and unit descriptions, Holes U1502A and U1502B.

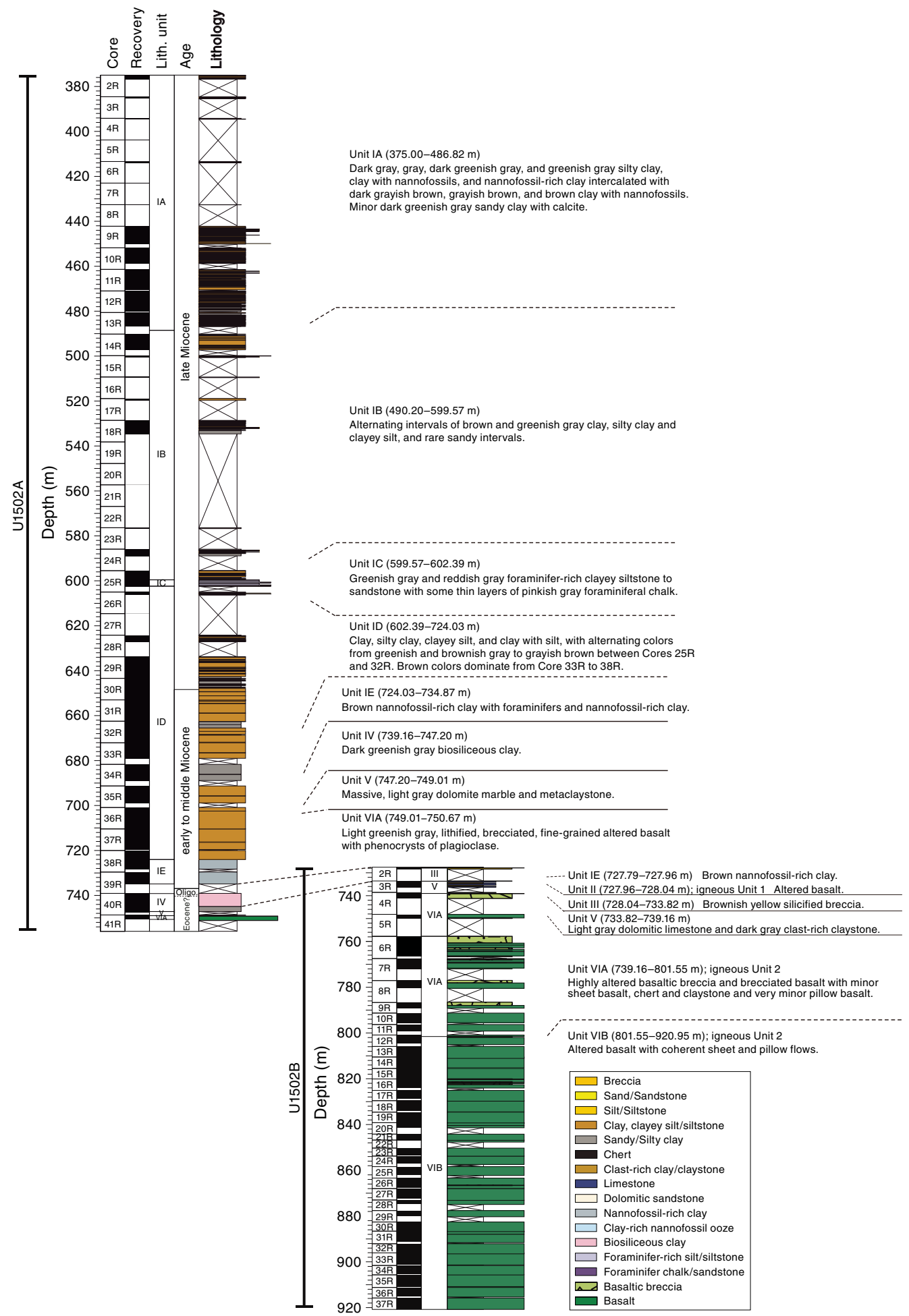

ture. Glassy pillow rinds are completely replaced, and multiple phases of veining and halos are ubiquitous throughout the rocks. Three vein types were observed: (1) white to green to black silicaepidote veins, (2) apple green pyrite-epidote veins, and (3) white silica and/or calcite veins. Sulfide mineralization (disseminated and veined) is widespread throughout Unit 2 and is dominated by pyrite, with minor sphalerite, chalcopyrite, and covellite.
Handheld portable X-ray fluorescence (pXRF) analyses show no significant differences in contents of alteration-resistant elements such as Ti and $\mathrm{Zr}$ in Unit 2, but Subunit 2a has lower $\mathrm{MgO}$, FeO, and $\mathrm{MnO}$ than Subunit 2b, which is consistent with the higher degree of alteration. Subunit $2 \mathrm{~b}$ is also strongly affected by secondary alteration, but areas of less intense alteration are indicated by higher magnetic susceptibility and high $\mathrm{CaO}$ and $\mathrm{Fe}_{2} \mathrm{O}_{3}$ contents. Unit 1 
Figure F19. Lithostratigraphic summary with main igneous lithologies and deformation structures, Holes U1502A and U1502B. A. Highly plagioclase-phyric basalt with up to $50 \%$ plagioclase phenocrysts. B. Highly altered, sparsely plagioclase phyric pillow basalt with a well-preserved pillow. C. Moderately altered aphyric basalt flow with sparse vesicles. Note the change to a bluish gray color. D. Slump folds. E. Microfaults showing striations/slickensides on exposed surfaces. F. Distributed shear geometries with shear bands and tilted bedding. G. Brecciated basalt. H. Basaltic breccia. I. Network of composite epidote-rich veins.

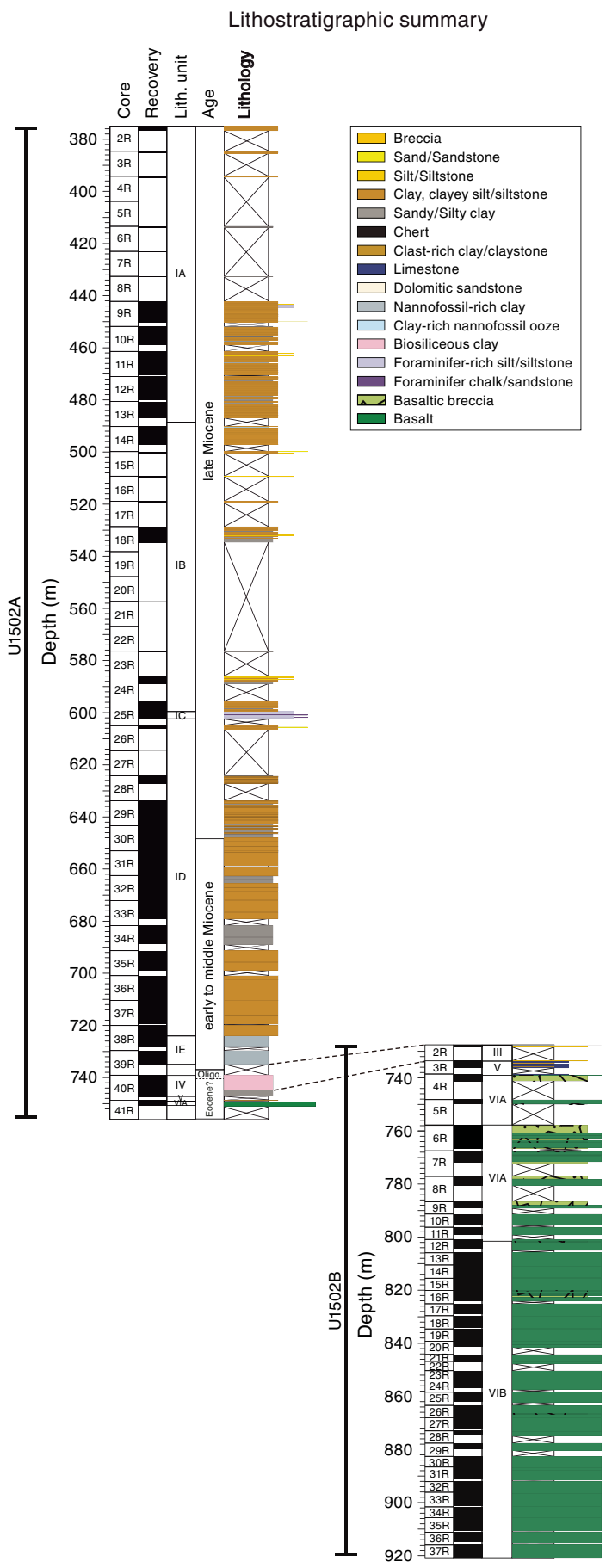

appears to be compositionally distinct from Unit 2 and has, for example, higher $\mathrm{Ti} / \mathrm{Zr}$ ratios.

\section{Structural geology}

Deformation structures are scarce in Unit I above Core 368U1502A-37R, with only a local, convolutely bedded sequence in

Deformation structures

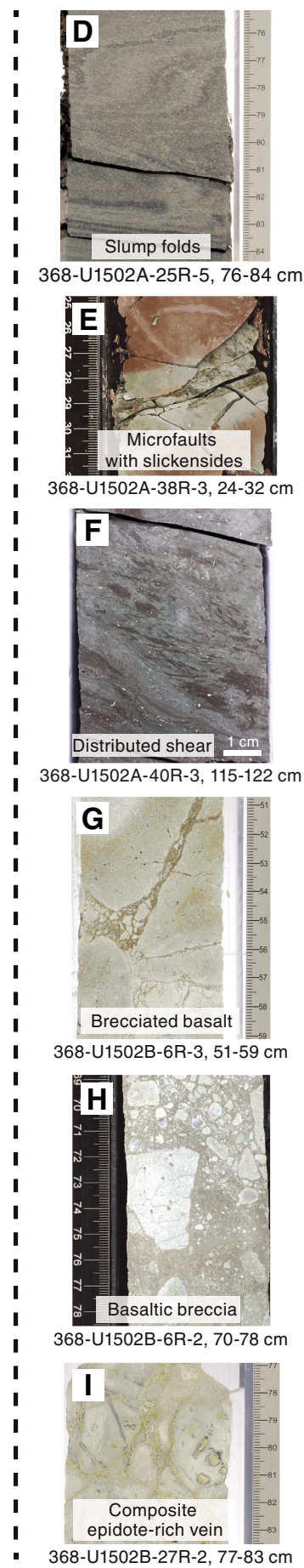

Core 25R. Downhole from Core 37R at $\sim 700 \mathrm{~m}$, a gradual increase in deformation structures was observed (Figure F19). Cores 37R through $39 \mathrm{R}$ are characterized by microfaults, as evidenced by downward-dip plunging striations and slickensides on exposed fracture surfaces, systematically associated with greenish halos. No deformation structures were encountered in Unit II. Unit III con- 
sists of extremely silicified breccia that was poorly recovered. The nature of this breccia, however, as sedimentary, tectonic, or hydrothermal remains unconstrained at the moment. In Unit IV, a smallscale transition from distributed to localized shear in unlithified sediments was documented. No deformation structures were encountered in Unit V.

Unit VI is essentially composed of basalts that were heterogeneously affected by brecciation and veining associated with the circulation of hydrothermal fluids. Subunit VIA is dominated by brecciated basalt/basaltic breccia, whereas Subunit VIB comprises a rather coherent series of lava flows crosscut by a multistage network of polymineralic veins. The uppermost part of Unit VI contains severely fractured and fragmented basalt locally filled by fine-grained unconsolidated greenish rock. Subunit VIA is characterized by diverse brecciation horizons associated with veins and microcracks. Depending on the intensity of fragmentation and the clast/matrix ratio, the rocks are referred to as brecciated basalt or basaltic breccia. A typically observed feature is the jigsaw-puzzle structure, suggesting possible in situ fragmentation. Macro- and microscopic observations show that the breccia-clasts consist mainly of sparsely to moderately plagioclase phyric basalts that were hydrothermally altered to variable degrees. Thus, formation of such breccias likely involved fluid-assisted fracturing of basalt. In contrast, Subunit VIB is characterized by a progressive decrease of breccia horizons and the development of different vein types, almost always polymineralic. Notably, vein composition and their orientation changes through Subunit VIB. Although numerous small-scale veins often related with major veins were observed, three first-order vein types were categorized: (1) composite silica-rich veins, (2) composite epidote-rich veins, and (3) composite carbonate- and/or silica-rich veins.

\section{Biostratigraphy}

All core catcher samples from Hole U1502A and selected samples from Hole U1502B were analyzed for calcareous nannofossils, foraminifers, diatoms, and ostracods. Additional samples were taken from the working-half core intervals when necessary to refine the ages. The preservation of calcareous microfossils is mostly good to moderate in the upper sections (Cores 368-U1502A-2R through $13 \mathrm{R}$ ) and moderate to poor in the lower sections (Cores $14 \mathrm{R}$ through 41R). Planktonic foraminifers and calcareous nannofossils are abundant to common in Cores $2 \mathrm{R}$ through $10 \mathrm{R}, 25 \mathrm{R}$, and $37 \mathrm{R}$ through $39 \mathrm{R}$ and rare to barren in all other sections. Diatoms were only observed in Sections 40R-1 through 40R-3. In Hole U1502B, foraminifers were observed only in Section 3R-1 and are represented by well-preserved agglutinated deep-water taxa. Ostracods are extremely rare; single occurrences were observed only in three samples in Hole U1502A (Samples 3R-CC, 4R-CC, and 5R-CC).

Fourteen planktonic foraminifer and calcareous nannofossil biostratigraphic events were used to provide an age-depth model for Site U1502 from the late Oligocene to the late Miocene. The Pliocene/Miocene boundary is placed tentatively in Core 368U1502A-2R, but it may be shallower than the cored section. The Miocene/Oligocene boundary was determined to lie between Samples 39R-CC and 40R-1, $7 \mathrm{~cm}$. Sedimentation rates vary from $\sim 10$ $\mathrm{mm} / \mathrm{ky}$ in the early-middle Miocene to $\sim 39 \mathrm{~mm} / \mathrm{ky}$ in the late Miocene. No planktonic microfossils were found in Hole U1502B, but a sample from the sandy interval in Core $3 \mathrm{R}$ revealed abundant and diverse abyssal agglutinated benthic foraminifers. The composition of this agglutinated benthic foraminifer assemblage provides a possible age of late Eocene for this interval.
Figure F20. Magnetization intensity vs. inclination showing the effect of the steep drilling overprint, Holes U1502A and U1502B. Basalts have higher magnetization intensity than sediments. Green lines represent the expected normal and reversal inclination at present latitudes.

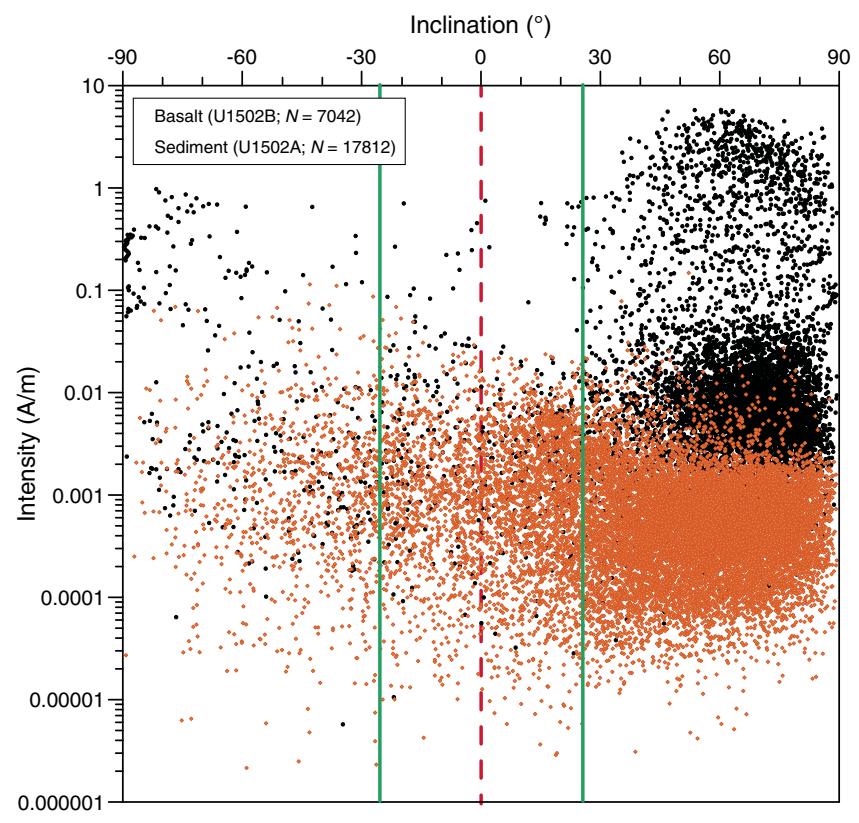

\section{Paleomagnetism}

The magnetic behavior of sediments at Site U1502 correlates with their color (greenish gray or reddish brown). Reddish brown sediment shows AF magnetization indicative of magnetite or titanomagnetite and hematite (responsible for the color). In contrast, greenish gray sediment hosts magnetite or titanomagnetite and pyrrhotite. The predominance of steep normal inclinations $\left(\sim 75^{\circ}\right.$; Figure F20) across all late Oligocene to late Miocene units (375.00-750.67 $\mathrm{m}$ ) affects the SRM section measurements and prevents any reliable magnetostratigraphy to be established for Holes U1502A and U1502B.

The basalt has NRM intensity one order of magnitude higher than sediment. The main magnetically remanent phase is titanomagnetite, but its alteration produces maghemite or hematite. Magnetic susceptibility ( $\mathrm{\kappa}$ ) has a bimodal distribution with a median at $327 \times 10^{-6}$ SI. $\mathrm{K}$ does not show any strong correlation with any chemical $\left(R^{2}=0.343\right.$ for $\mathrm{Fe}_{2} \mathrm{O}_{3}$ wt $\left.\%\right)$. Intervals of high $\mathrm{\kappa}$ might correspond to the bottoms of flows with a massive, less altered structure. Altered basalts have higher Koenigsberger ratios $\left(Q_{\mathrm{n}}=1-10\right)$ than fresher basalts $\left(Q_{\mathrm{n}}=0.001-1\right)$. The mean dip of magnetic foliation is $8^{\circ}$.

Cores 368-U1502B-9R and 10R show less-pervasive drilling overprint, and two discrete samples show both a normal (soft) component and a reverse (hard) component, suggesting a possible reversal.

\section{Geochemistry}

Site U1502 contains very low high-hydrocarbon gas abundances and TOC, nitrogen, and sulfur contents, likely reflecting the poor preservation of organic matter. Instances of high carbonate content are associated with siderite, and on occasion this mineral comprises $>50 \mathrm{wt} \%$ by mass of intervals in lithostratigraphic Subunit ID. The interstitial water at Site U1502 is enriched in $\mathrm{Ca}, \mathrm{Mg}$, and $\mathrm{K}$ and has notably high alkalinity but is depleted in $\mathrm{Na}, \mathrm{Cl}$, and $\mathrm{Br}$. The linear 
Figure F21. Physical property records, Site U1502.

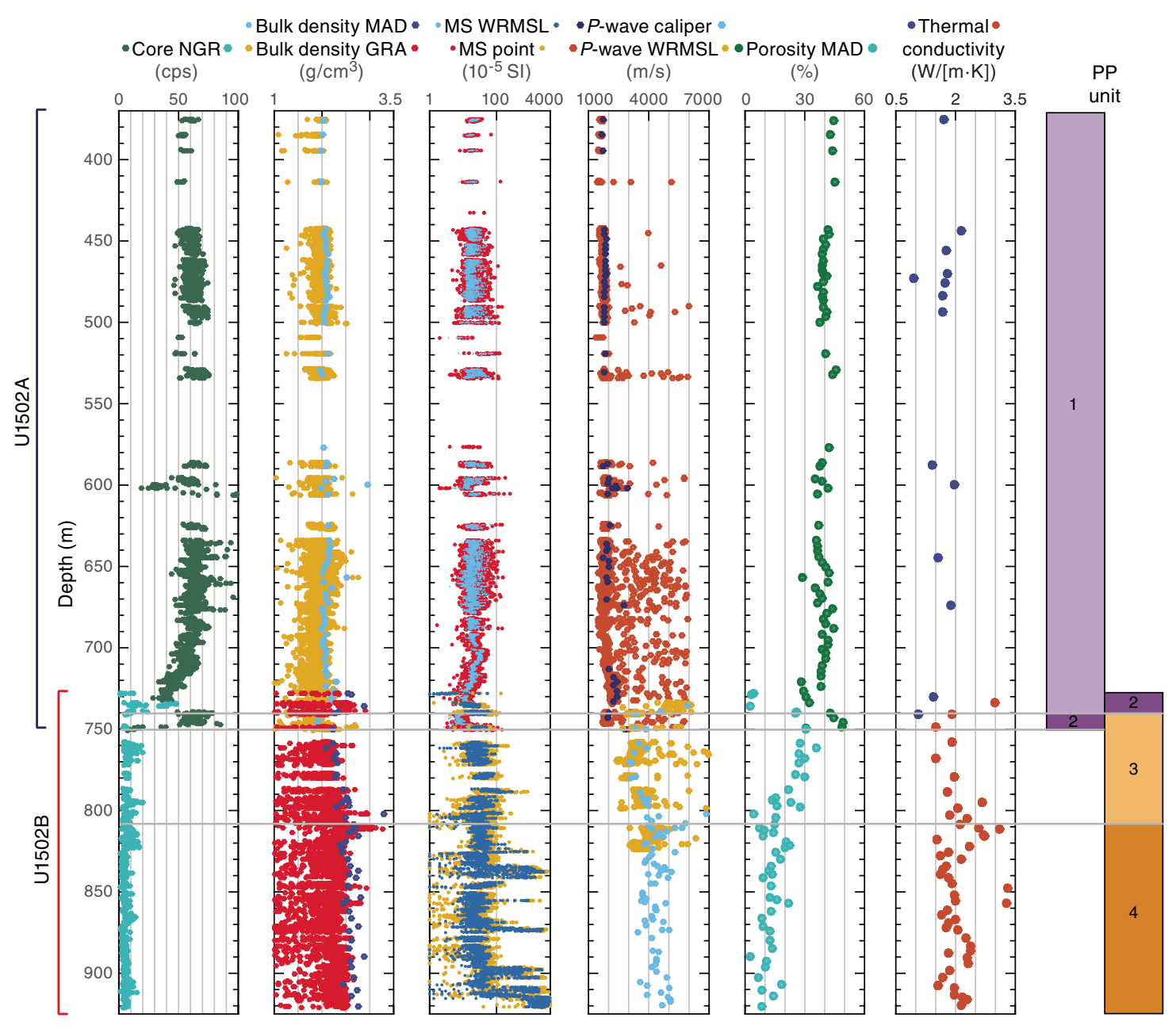

increase of major anion and cation contents implies upward movement of fluid from deeper sediments. The hemipelagic sediments in Unit I have some similarities to the geochemical characteristics of the hemipelagic and pelagic units at Sites U1501 and U1505, but Site U1502 sediments are enriched in Fe, K, and clay concentrations, likely as a result of regions of increased alteration. All of the analyzed igneous rocks from Units II-VI are heavily altered, although samples from igneous lithologic Subunit $2 \mathrm{~b}$ are altered to a lesser degree than those from Subunit 2a.

\section{Physical properties}

Physical property data acquired at Site U1502 include density, magnetic susceptibility, $P$-wave velocity, NGR, color reflectance, and thermal conductivity (Figure F21). These data allow us to characterize four physical property (PP) units. PP Unit 1 (375-740 m) corresponds to the nannofossil-rich and biosiliceous-rich clay lithologies and exhibits small variations in NGR between 50 and 70 counts/s and uniformly increasing $P$-wave velocity with depth that averages $<2500 \mathrm{~m} / \mathrm{s}$. Unit 1 sediments have similar porosity to those recorded at nearby Sites U1499 and U1500 in the same depth interval, suggesting the same compaction history. A significant increase in bulk density (up to $2.7 \mathrm{~g} / \mathrm{cm}^{3}$ ) in Core 368-U1502B-3R is associated with strongly lithified limestone beds. Variations of high and low magnetic susceptibility values correspond to sediment color changes in Unit 1 and may be controlled by the amount of pyrrhotite in the sediments.

PP Unit $2(740-750 \mathrm{~m})$ in Hole U1502A is characterized by lower $P$-wave velocity and bulk density and higher NGR than the strata above. Low density and $P$-wave velocity found in Unit 2 reflect the clast-rich claystone from lithostratigraphic Unit V.

PP Units 3 and 4 represent the basaltic basement and are characterized by relatively low NGR ( $<10$ counts/s), high density, and $P$ wave velocity that vary over a broad range $(3000-6000 \mathrm{~m} / \mathrm{s})$. The boundary between Units 3 and 4 is marked by an abrupt increase in density, $P$-wave velocity, and thermal conductivity and coincides with the change from igneous lithologic Subunit 2a to 2b. Prominent magnetic susceptibility peaks (up to $4000 \times 10^{-5} \mathrm{SI}$ ) in Units 3 and 4 correspond to relatively less altered basalt. Thermal conductivity in Units 3 and 4 are variable but generally increases in line with decreasing porosity with depth.

\section{Downhole measurements}

Wireline logging was conducted in Hole U1502B using a modified triple combo tool string and the VSI tool string. The modified triple combo tool string included the HNGS, HLDS, and Dipole Sonic Imager (DSI) for acoustic velocity. The triple combo run collected good data downhole from $875.3 \mathrm{~m} \mathrm{(} \mathrm{45} \mathrm{m} \mathrm{above} \mathrm{the} \mathrm{bottom}$ of Hole U1502B) and allowed us to define eight logging units, which 
correlate in great part to the lithostratigraphic units and core physical properties. Logging Units $1-5$ are defined by data collected through the casing and drill pipe. Unit 6 data was collected outside the casing but inside the drill pipe, whereas data in Units 7 and 8 were collected in the open hole. For measurements inside the casing and/or drill pipe, only NGR and the associated K, Th, and U components provide meaningful data, although they are highly attenuated by the casing and/or drill pipe. Open borehole conditions from the bottom of the casing at $723 \mathrm{~m}$ to $875.3 \mathrm{~m}$ were generally good, with measured diameters from 12 to 14.5 inches. Log and core data generally show good agreement, and downhole measurements provide information in zones of poor core recovery in Hole U1502B. The log data exhibit increasing density and $P$-wave velocity with depth. The amplitude of NGR increases gradually with depth throughout Units $1-3$ (seafloor to $\sim 630 \mathrm{~m}$ ), with an interval of relatively constant values between 150 and $350 \mathrm{~m}$. NGR values are lowest in Units 4-8 ( 630-850 m).

The VSI tool string was run only inside the casing because the tool could not pass through an obstruction encountered at the end of the casing. Eight stations were attempted. The two deepest stations (at 715.1 and $695.2 \mathrm{~m}$ ) are associated with large noise levels, which were possibly caused by poor mechanical coupling of the casing with the surrounding formation. The remaining upper six stations, located at 290.2, 350.3, 450.3, 550.1, 590.3, and $630.3 \mathrm{~m}$, recorded good quality waveforms.

\section{Site U1503}

\section{Background and objectives}

Site U1503 (proposed Site SCSII-9B; Sun et al., 2016b) is located at 3868 mbsl near the top of the structural high named Ridge C (Figures F3, F22). Ridge $C$ is the most seaward ridge of the three margin-parallel Ridges $\mathrm{A}, \mathrm{B}$, and $\mathrm{C}$ that characterize the lower continental slope underlain by thin $(5-7 \mathrm{~km})$ crust. Ridge $C$ is believed to represent at least partly, if not fully, igneous crust and

Figure F22. Bathymetry at Site U1503 and location of the site in relation to seismic Lines 15 ecLW5 and 08ec1555.

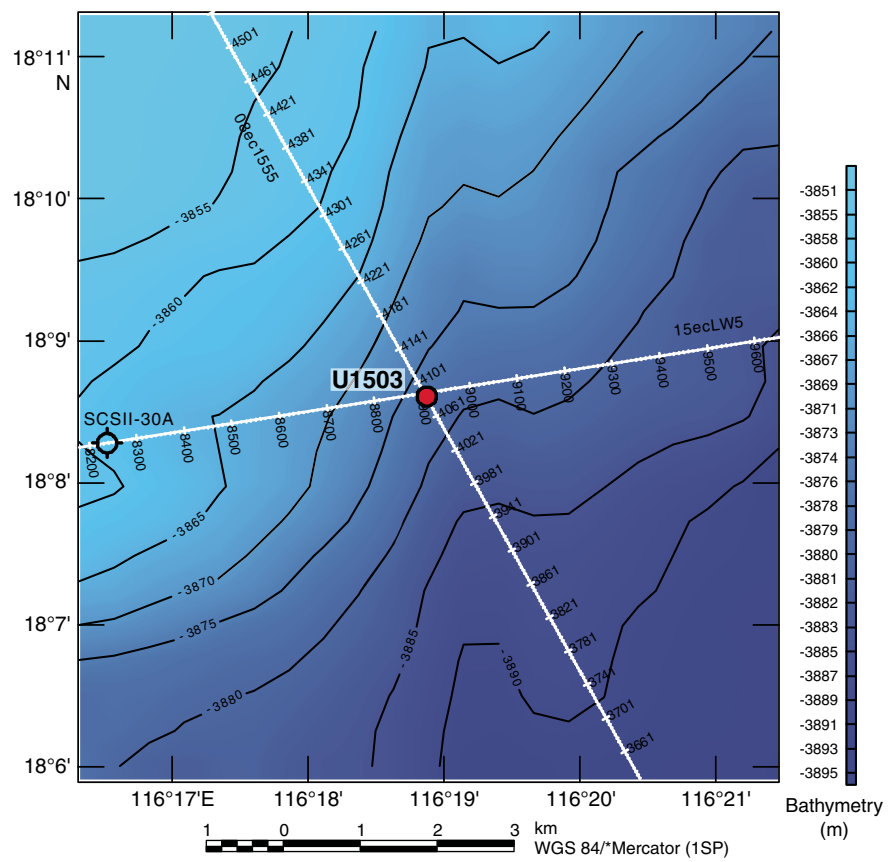

hence the completion of continental breakup along this margin segment of the northern SCS.

A key operational objective of Site U1503 was to sample the lowermost $\sim 300 \mathrm{~m}$ of sediments on top of basement to constrain the age and subsidence history of the crust at this location, the timing of normal faulting, and the environment of the early half-graben fill. The most important goal was to sample the igneous stratigraphy to at least $100 \mathrm{~m}$ below the basement. Because of a rig floor equipment failure (drawworks), we abandoned the site after installing casing in Hole U1503A to $991.5 \mathrm{~m}$.

Deep, representative sampling of the basaltic material at this site would have provided an important reference frame for breakup modeling. With an estimated $1640 \mathrm{~m}$ sediment thickness overlying basement, obtaining basement samples and log data at this site represented a challenging operation.

\section{Operations}

To reach our objectives, we conducted operations in one hole (U1503A; $18^{\circ} 08.6300^{\prime} \mathrm{N}, 116^{\circ} 18.8456^{\prime} \mathrm{E} ; 3868 \mathrm{mbsl}$ ) (Table T2). We successfully installed a reentry system and $991.5 \mathrm{~m}$ of $10^{3 / 4}$ inch casing in Hole U1503A. However, we were unable to deepen the hole below the casing because of repeated breakdowns of the low clutch diaphragm in the drawworks and concerns that we did not have enough spares to last the remainder of the expedition. Without the drawworks' low clutch, we could not conduct drilling operations deeper than $3400 \mathrm{~m}$ (water depth plus penetration depth). Because Site U1503 had a planned depth of 5695 m (water depth plus penetration depth), we abandoned Hole U1503A without addressing any scientific objectives. Hole U1503A remains cased and open for possible future occupation.

\section{Site U1504}

\section{Background and objectives}

Site U1504 (alternate Site SCSII-27A) was proposed during Expedition 367 and approved by the Environmental Protection and Safety Panel during Expedition 368 as an alternate site should there be time left following completion of the high-priority sites included in the Scientific Prospectus (Sun et al., 2016b). Expedition 368 occupied Site U1504 because of the inability to continue drilling below the $990 \mathrm{~m}$ deep, cased Hole U1503A. Most of our remaining approved sites were in water deeper than $3400 \mathrm{~m}$ and/or required deep penetration. One exception was Site U1504, which is located at $2823 \mathrm{mbsl} \sim 45 \mathrm{~km}$ east of Site U1501 on the OMH and has a shallow coring target (Figures F3, F23) and targets the nature of basement within the COT.

\section{Operations}

Two holes were drilled at Site U1504 (Table T2). In Hole U1504A ( $18^{\circ} 50.9199^{\prime} \mathrm{N}, 116^{\circ} 14.5397^{\prime} \mathrm{E}$; $\left.2816.6 \mathrm{mbsl}\right)$, we cored with the RCB system from the seafloor to metamorphic basement at $134.8 \mathrm{~m}$ and then into basement to $165.5 \mathrm{~m}$, recovering $52.77 \mathrm{~m}$ (32\%). In Hole U1504B ( $200 \mathrm{~m}$ southeast of Hole U1504A; $18^{\circ} 50.8213^{\prime} \mathrm{N}, 116^{\circ} 14.5978^{\prime} \mathrm{E} ; 2843.0 \mathrm{mbsl}$ ), we drilled without recovery to $88.2 \mathrm{~m}$, cored with the RCB system to metamorphic basement at $107.9 \mathrm{~m}$, and then cored into basement to $200 \mathrm{~m}$, recovering $21.48 \mathrm{~m}(19 \%)$.

\section{Lithostratigraphy}

The succession recovered at Site U1504 includes two sedimentary units (I and II) underlain by a metamorphic unit (III). Lithostratigraphic Unit I (early Miocene-Pleistocene) is dominated by 
Figure F23. Bathymetry at Site U1504 and location of the site in relation to seismic lines. Note that the clear offset in the bathymetry along the margin may indicate some transform offset in the deeper margin structure.

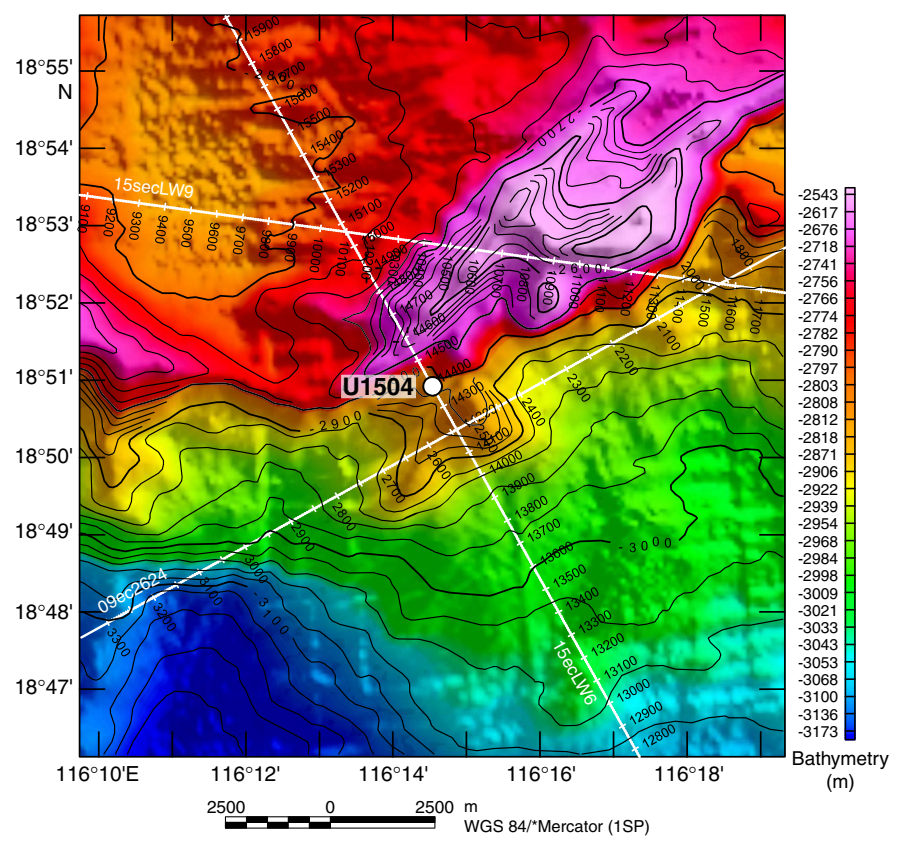

nannofossil and foraminiferal ooze and minor nannofossil-rich clay and is divided into four subunits (IA-ID). Subunit IA (Hole U1504A $=17.50-46.59 \mathrm{~m}$ ) is composed of nannofossil-rich clay, nannofossil ooze, nannofossil ooze with biogenic silica, and clay-rich nannofossil ooze. The color of the ooze gradually changes downhole from dark greenish gray to greenish gray and gray. Distinct intervals contain more silt. Thin silt laminations are often disrupted by bioturbation. Layering is contorted at the base of the subunit. Subunit IB (Hole U1504A $=46.59-59.73 \mathrm{~m}$ ) is composed of light brown foraminifer-rich nannofossil ooze and pale brown nannofossil ooze with foraminifers. Subunit IC (Hole U1504A $=65.80-104.99 \mathrm{~m}$ ) is composed of light greenish gray, greenish gray, light brownish gray, pale brown, and light gray nannofossil ooze with clay and greenish gray clay-rich nannofossil ooze intercalated with light gray nannofossilrich foraminiferal ooze with clay, light brownish gray foraminiferrich nannofossil ooze, and foraminifer-rich nannofossil ooze with clay. Subunit ID (Hole U1504A = 104.99-112.66 m; Hole U1504B $=88.20-92.31 \mathrm{~m}$ ) is composed of light brown to yellowish brown nannofossil ooze with foraminifers intercalated with pink or brownish yellow foraminifer-rich nannofossil ooze. Unit II (possibly Eocene; Hole U1504A = 114.72-134.80 m; Hole U1504B = 97.90$107.91 \mathrm{~m}$ ) is clast-supported, bioclast-rich limestone with larger benthic foraminifers (as large as $15 \mathrm{~mm}$ ). Unit III (age unknown; Hole U1504A = 136.40-163.70 m; Hole U1504B = 117.40-196.28 $\mathrm{m}$ ) is composed of fine- to coarse-grained epidote-chlorite schist (Subunit IIIA) and calc-silicate schist (Subunit IIIB) with granofels clasts.

\section{Metamorphic petrology}

We recovered $27 \mathrm{~m}$ (Hole U1504A) and $79 \mathrm{~m}$ (Hole U1504B) of a variety of mylonitic epidote-chlorite to calc-silicate schists containing granofels clasts. Recovery was $<20 \%$ in metamorphic lithologic Unit 1. Lithologic changes with depth and between the two holes were observed, and Unit 1 is divided based on a change in the predominant metamorphic lithology (Figure F24). Metamorphic lithologic Subunit 1a was recovered in both Holes U1504A and U1504B and consists of greenish gray, microcrystalline to coarsegrained epidote-chlorite schist with dark greenish gray granofels clasts $(<10 \mathrm{~cm})$ and epidote-chlorite breccia. The schists show a strong mylonitic foliation, whereas the clasts have generally isotropic textures showing local weakly developed foliation. Both the schist and the granofels clasts show, in general, a comparable mineral assemblage consisting of epidote, chlorite, feldspar, and quartz \pm other phyllosilicates and accessory minerals and locally isolated subhedral dark minerals (pyroxene?). The granofels clasts are often crosscut by a network of quartz veins. Subunit $1 \mathrm{~b}$ contains an alternation of calc-silicate schist and epidote-chlorite schist with granofels clasts, epidote and/or chlorite granofels, chlorite schist with epidote, epidote-chlorite gneiss, and minor marble. The lithologies are fine grained to coarse grained with mostly an inequigranular texture and some bimodal or equigranular textures, and the schistose sections show a strong mylonitic foliation. Several of the schists show reddish brown alteration, and late calcite veins crosscut the foliation of the deepest schists recovered (e.g., in Core 368U1504A-20R). Minerals observed are epidote, quartz, chlorite, calcite, and feldspar. Subunit $1 \mathrm{~b}$ contains numerous clasts with variable lithologies: cryptocrystalline granofels either with or without quartz and/or calcite veins, porphyritic rocks with tabular phenocrysts (possibly altered plagioclase), brecciated (epidote, calcite, and/or quartz) veins, and foliated granofels.

Handheld pXRF analyses show an average mafic igneous composition for both the schist and the clasts but with a spread toward ultramafic (in Hole U1504B Subunit 1a) and more felsic compositions (in Subunit 1b). A clear change in sulfur contents occurs between Subunits 1a and 1b, the latter of which is below the detection limit. High $\mathrm{Nb}$ contents compared to MORB indicate a potentially enriched source for the protolith.

Lithostratigraphic Unit III (metamorphic lithologic Unit 1) consists of mylonitic greenschist facies metamorphic rocks, as indicated by the presence of epidote and chlorite. We infer that the protolith most likely was breccia based on the different clast sizes and types and styles of deformation. The protolith likely had a mafic igneous composition. It is, however, unclear if this breccia with mafic clasts has a sedimentary origin (e.g., volcaniclastic) or represents a potentially hydrothermally altered form of basalt, gabbro, or ultramafic protolith. At present, the metamorphic evolution of this unit and its possible connection with the opening of the SCS is unknown.

\section{Structural geology}

Lithostratigraphic Unit I shows subhorizontal bedding and locally some minor possible slump folds, as observed in Section 368U1504A-5R-1. Unit II is devoid of any deformation structures. The metamorphic basement at Site U1504 is formed by greenschist facies mylonitic epidote-chlorite schists and calc-silicate schists (Unit III). The rocks preserve distinct deformation structures resulting from changes in the mode of deformation (brittle/ductile); the modal amount of quartz + feldspar governing the (local) rheological behavior; the amount of accumulated strain; the occurrence of variably sized (up to decimeter scale), prekinematic, heterolithic clasts that mostly form rigid (i.e., internally undeformed) bodies in the ductile foliation; and/or superimposed multiple deformation phases. The steeply dipping (up to $75^{\circ}$ ) mylonitic foliation is characterized by distinct morphologies: (1) a widely spaced anastomosing foliation associated with leucocratic bands; (2) a tight, closely 
Figure F24. Lithostratigraphic, petrographic/petrological, and structural observations with strong focus on the metamorphic basement, Site U1504. A, B. Clastsupported limestone with large benthic foraminifers and coral fragments. C. Severely quartz-veined, angular clast of chlorite-epidote granofels enclosed in mylonitic foliation of a typical epidote-chlorite schist. D. Steep $\left(\sim 75^{\circ}\right)$ widely anastomosing foliation in a quartz + feldspar-rich variety of the rock. Arrow $=$ extensively stretched veined clast of chlorite-epidote granofels oriented parallel to the foliation. E. Epidote-chlorite schist with granofels clasts split parallel to the $x, y$-plane of finite strain. Large granofels clast is crosscut by a shear band in the epidote-chlorite schist. Several sigma clasts lie right above the shear band. Both deformation structures indicate normal sense of shear. A late, postkinematic vein crosscuts both the mylonitic foliation and the granofels clast. F. Tight foliation affected by crenulation cleavage in quartz-poor (i.e., more melanocratic) variety of the rock. G. Local occurrence of foliated impure calcite marble. H. Veined and altered aphyric mafic granofels clast (left side) and granofels clast interpreted as protolithic epidote vein (right side). Both clasts are internally undeformed but show synkinematic deformation together with the mylonitic fabric at their rims. I. Rigid (left) and strongly deformed (upper end) granofels clasts embedded in calc-silicate schist. Note the deflection of the mylonitic foliation at the clast boundaries. J. Long piece of core showing the characteristic morphology of the mylonitic foliation in calc-silicate schist of Subunit IIIB. Note the steep inclination and anastomosing geometry enclosing heterolithic clasts that are strongly elongated, folded, and oriented parallel to the foliation.

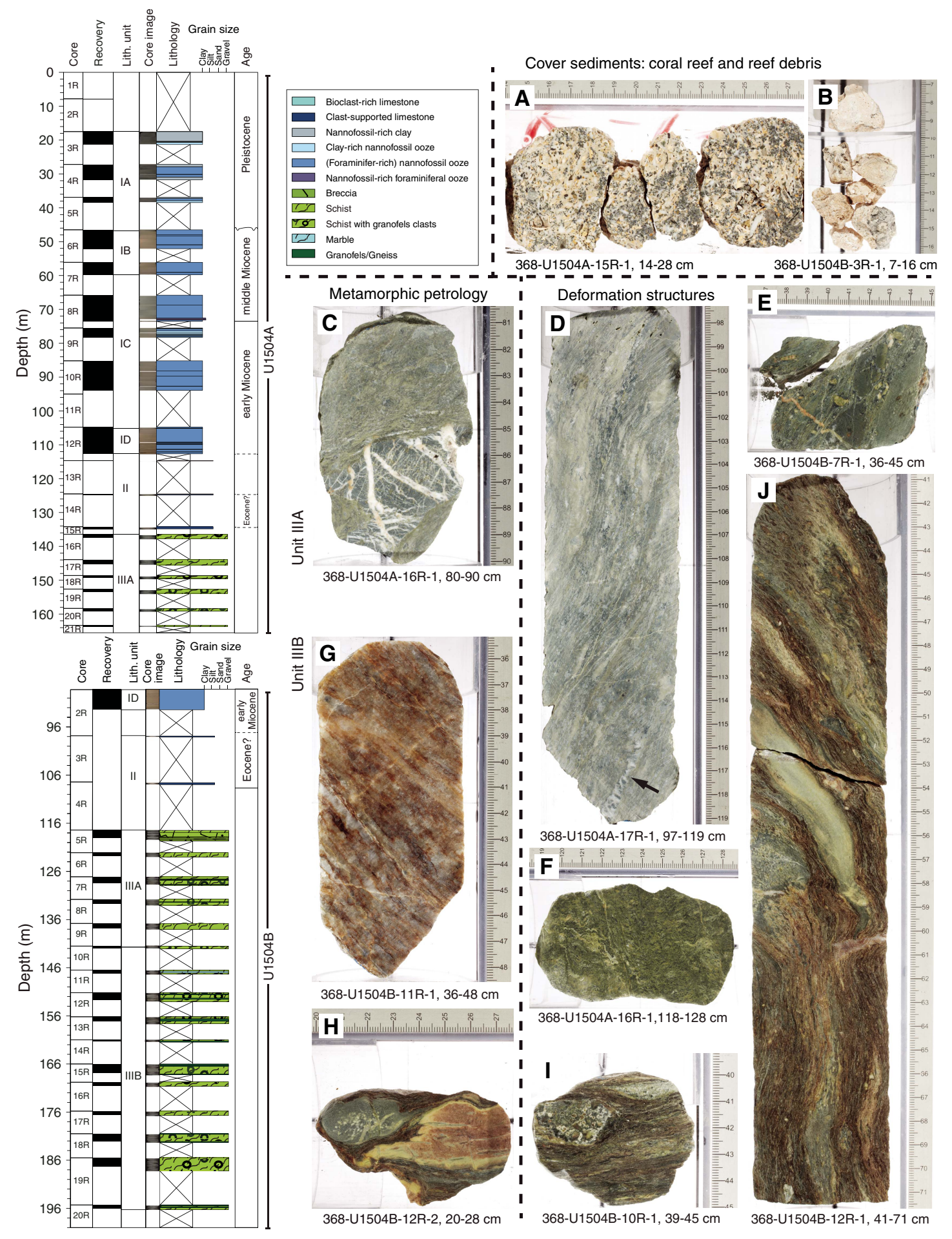


spaced, and often crenulated foliation associated with more melanocratic schist variations; and (3) a tight anastomosing foliation associated with calc-silicate schists enclosing angular to rounded heterolithic granofels clasts. Locally, the sense of shear is indicated by shear bands and sigma clasts. In metamorphic lithologic Subunit 1a (Figure F24), granofels clasts are consistently microcrystalline (chlorite + epidote) and dismembered by a network of mostly parallel and perpendicular quartz veins cutting each other. They often form apparently stretched, elongated bodies oriented parallel to the foliation. Subunit 1b shows a wide range of prekinematic (mostly mafic) clasts enclosed by the foliation. Encountered varieties encompass highly phyric to aphyric rocks, as well as fragmented former (epidote/calcite/quartz) vein fillings. In some cases, such clasts show ductile internal deformation. Clast boundaries can be either distinctly sharp or diffuse, the latter indicating mechanical and/or chemical interactions with the surrounding foliation. Deformation in Subunit 1b is presumably strongly controlled by an inherited (protolithic) brecciated structure.

\section{Biostratigraphy}

All core catcher samples at Site U1504 were analyzed for calcareous nannofossils, foraminifers, and diatoms. Additional samples were taken from intervals in the working-half core sections when necessary to refine the ages. Preservation of calcareous microfossils is good to very good in Cores $368-\mathrm{U} 1504 \mathrm{~A}-2 \mathrm{R}$ through $12 \mathrm{R}$, and $368-\mathrm{U} 1504 \mathrm{~B}-2 \mathrm{R}$ and is poorly preserved (recrystallization) in the reefal limestone below Core 368-U1504A-12R. Planktonic foraminifers and calcareous nannofossils are abundant in Cores 368U1504A-2R through 12R and 368-U1504B-2R and barren in Cores $368-U 1504 A-13 R$ through $15 R$. Diatoms are present but poorly preserved in Cores 368-U1504A-2R through 5R and absent in rest of the samples. Twenty biostratigraphic datums were identified in a succession from the late Pleistocene to the early Miocene.

A possible hiatus between the early Pleistocene and late Miocene was determined in Core 368-U1504A-6R by abrupt planktonic foraminifer and nannofossil assemblage changes. Sedimentation rates at this site varied from $\sim 6 \mathrm{~mm} / \mathrm{ky}$ in the early middle Miocene to $\sim 22 \mathrm{~mm} / \mathrm{ky}$ during the Pleistocene.

Cores 368-U1504A-13R through $15 \mathrm{R}$ are mainly composed of reefal and larger benthic foraminiferal limestone. Thin section examination of these carbonate rocks indicates the presence of abundant Nummulites, suggesting an Eocene age. The abundant larger benthic foraminifers indicate deposition in a warm shallow-marine environment. In contrast, the abundant planktonic foraminifers and calcareous nannofossils in the carbonate ooze in the overlying sedimentary section (Cores $2 \mathrm{R}$ through $12 \mathrm{R}$ ) indicate a deep-water environment since the early Miocene.

\section{Paleomagnetism}

Most of the discrete sediment samples analyzed show an initial soft magnetic behavior attributed to titanomagnetite followed by a gyroremanent magnetization (GRM) greater than $70 \mathrm{mT}$ attributed to greigite, a mineral already identified in Hole U1501C. Consistently steep normal inclinations $\left(\sim 60^{\circ}\right)$ across all sedimentary units indicate a significant drilling overprint that is removed by AF demagnetization up to $15 \mathrm{mT}$. A succession of nine normal and eight reversed polarities are defined, particularly in the upper part of the cores.

Discrete samples show low $\mathrm{k}$ values, a moderate degree of magnetic anisotropy, and strongly oblate symmetry, probably of depositional origin. This subhorizontal planar fabric indicates deposition in a calm, pelagic environment with moderate traction.
NRM intensities of metamorphic rocks, measured on the SRM and on four discrete cubes, are relatively weak and indicate a complex magnetic assemblage composed of magnetite and hematite. The anisotropy of magnetic susceptibility (AMS) fabrics consistently dip steeply and show a moderate to high degree of magnetic anisotropy, oblate symmetries, and oblique magnetic lineations, possibly indicating an oblique motion in this high-strain shear zone.

\section{Geochemistry}

Hydrocarbon gases were not detected above background levels at Site U1504, and TOC, TN, and TS contents were low ( $<0.5 \mathrm{wt} \%)$. Instances of high carbonate content were associated with bioclastrich and clast-supported limestone. The upper part of the sediment was not cored. Interstitial water data from the cored sediments are broadly comparable to other sites.

\section{Physical properties}

Four physical properties (PP) units are identified at Site U1504 according to variations in the core physical properties. Core material in PP Units 1 and 2 consists of soft sediments. In general, with respect to Unit 2, Unit 1 has a higher average NGR ( $\sim 30$ versus 20 counts/s), a weaker color reflectance (mean $L^{*}$ of $\sim 40$ versus 50 ), and a lower average red, green, blue (RGB) value (100 versus 150 ). These changes in physical properties between Units 1 and 2 correspond to a switch in sediment composition from nannofossil-rich clay to nannofossil ooze. A general increase in bulk (from $\sim 1.4$ to 1.8 $\mathrm{g} / \mathrm{cm}^{3}$ ) and dry (from $\sim 0.7$ to $1.2 \mathrm{~g} / \mathrm{cm}^{3}$ ) densities and a downhole decrease in porosity (from $75 \%$ to $56 \%$ ) in Units 1 and 2 mainly indicate sediment compaction with time. The boundary between Units 1 and 2 is marked by a relatively rapid increase in $P$-wave velocity and bulk density and a rapid decrease in porosity compared with the general trends mentioned above. This physical property boundary corresponds to an unconformity in the seismic profile and to a hiatus confirmed by the biostratigraphic data.

$P$-wave velocity and bulk density increase from $\sim 3800$ to 5000 $\mathrm{m} / \mathrm{s}$ and from $\sim 2.4$ to $2.9 \mathrm{~g} / \mathrm{cm}^{3}$, respectively, in Unit 3, which corresponds to a transition in lithology from coral-rich limestone to clast-supported limestone. Coral-rich limestone in the upper portion of Unit 3 is also associated with a moderately high porosity of $\sim 23 \%$. Unit 4 is characterized by uniformly high velocity of $\sim 5500$ $\mathrm{m} / \mathrm{s}$, high bulk density of $\sim 2.9 \mathrm{~g} / \mathrm{cm}^{3}$, and low porosity of $\sim 3 \%$, which correspond to the epidote-chlorite schist. A large increase in both velocity and density at the Unit $2 / 3$ and Unit 3/4 boundaries corresponds to strong reflectors in the seismic data. The gradual downhole increase in thermal conductivity values at shallow depths is likely due to progressive compaction of the sediments.

\section{Background and objectives}

Site U1505

Site U1505 (proposed Site SCSII-3D) is located at $2916.6 \mathrm{~m}$ water depth on a broad regional basement high (Figure F25). This site was an alternate to Site U1501, should time be left for drilling following completion of the high-priority sites included in the Scientific Prospectus (Sun et al., 2016b). Site U1505 was included in Expedition 368 because it might complement findings at Site U1501, and it was in the operational limits of the $3400 \mathrm{~m}$ drill string imposed by the failure of the drawworks.

Both Sites U1505 and U1501 are located on the same structural high at similar water depths and are $10.5 \mathrm{~km}$ apart (Figure F2). The seismic section at Site U1505 generally shows a more horizontal orientation of the seismic reflectors and concordant relationship of the strata than the one at Site U1501, indicating the sediment sequence 
Figure F25. Bathymetry at Site U1505 and location of the site in relation to seismic Lines 04 ec1555 and 15eclLW1. Note that the site is not at the exact crossing of Lines $04 \mathrm{ec} 1555$ and 15 eclLW1.

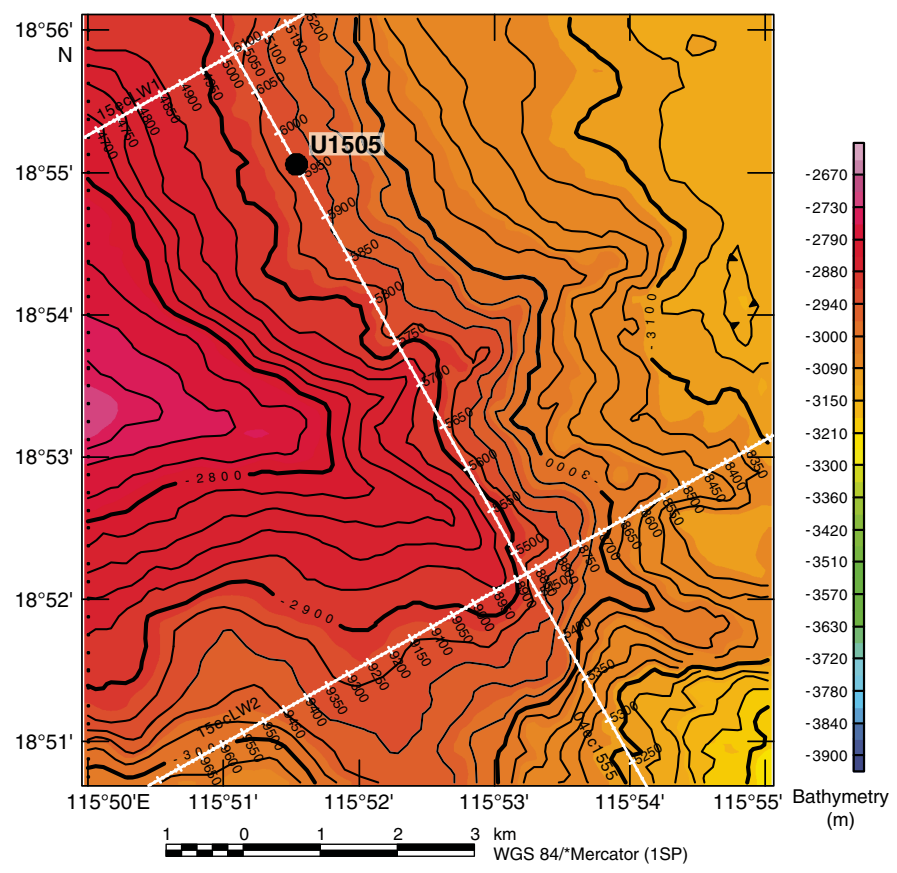

at Site U1505 should be more complete. The key objective at Site U1505 was to sample the stratigraphic record above seismic Unconformity T80 (inferred before drilling to be $\sim 38 \mathrm{Ma}$ ), and specific goals were to constrain both (1) the sediment responses to the tectonic events and basin evolution since the Eocene and (2) Neogene paleoceanographic and paleoclimatological changes along the northern SCS margin.

The relatively shallow $2916.6 \mathrm{~m}$ water depth at Site U1505 makes it one of the few ODP/Integrated Ocean Drilling Program/IODP sites above the modern CCD of the SCS. The site's hemipelagic deposits, rich in calcareous microfossils, enable the application of stable isotopes, faunal analyses, and other multidisciplinary methods. Key objectives were to reconstruct the east Asian monsoonal climate record in the SCS and upper- and deep-water variations in the western Pacific. Site U1505 will, for the first time, provide an almost continuous sequence of paleoceanographic studies at orbital and millennial timescales since the late Eocene in the SCS. We cored two deep holes at this site with the APC/XCB system to obtain a continuous record of the Pliocene-Pleistocene interval for high-resolution paleoceanographic studies.

\section{Operations}

Four holes were cored with the APC and XCB systems at Site U1505 (Table T2). In Hole U1505A ( $18^{\circ} 55.0560^{\prime} \mathrm{N}, 115^{\circ} 51.5369^{\prime} \mathrm{E}$; $2916.6 \mathrm{~m}$ water depth), Core $1 \mathrm{H}$ misfired and recovered only $0.3 \mathrm{~m}$. In Hole U1505B $\left(18^{\circ} 55.0562^{\prime} \mathrm{N}, 115^{\circ} 51.5370^{\prime} \mathrm{E} ; 2918.6 \mathrm{~m}\right.$ water depth), a $3.23 \mathrm{~m}$ long mudline core was recovered for future education and outreach activities. Hole U1505C (18 55.0570' N, $115^{\circ} 51.5370^{\prime} \mathrm{E} ; 2917.4 \mathrm{~m}$ water depth) was cored with the APC system to $317 \mathrm{~m}$ and then cored with the XCB system to $480.2 \mathrm{~m}$, recovering $480.15 \mathrm{~m}$ (100\%). Hole U1505D $\left(18^{\circ} 55.0485^{\prime} \mathrm{N}\right.$, $115^{\circ} 51.5501^{\prime} \mathrm{E}$; $2917.5 \mathrm{~m}$ water depth) was cored with the APC system to $184.5 \mathrm{~m}$ and recovered $191.43 \mathrm{~m}$ (104\%). Downhole logging with a modified triple combo tool string was conducted in Hole
U1505C from $341.2 \mathrm{~m}$ uphole. The maximum drilling depth of $480.2 \mathrm{~m}$ was determined by the possible maximum total length $(3400 \mathrm{~m})$ of drill string deployment.

\section{Lithostratigraphy}

The sediment succession recovered at Site U1505 extends from the Oligocene to the Pleistocene. Two sedimentary units (I and II) were observed (Figure F26). Lithostratigraphic Unit I is dominated by nannofossil ooze with varying amounts of foraminifers and clay, as well as biogenic silica in the upper interval of the hole. Unit I is divided into three subunits (IA-IC). Subunit IA (Hole U1505C = $0.00-27.76 \mathrm{~m}$ ) is composed of dark greenish gray and greenish gray biosiliceous-rich clay with nannofossils, nannofossil-rich clay with biogenic silica, and nannofossil-rich biosiliceous ooze with clay. The abundance of biogenic silica decreases downhole. A pinkish gray, 6 $\mathrm{cm}$ thick, slightly fining upward ash layer occurs at $20.8 \mathrm{~m}$ (Hole U1505C), and ash pods were observed at $20.3 \mathrm{~m}$ in Hole U1505D. Subunit IB (Hole U1505C $=27.76-273.39 \mathrm{~m}$ ) is composed of gray to brown nannofossil ooze with minor silty intervals. The color change reflects the varying abundance of foraminifers and clay. Subunit IC (Hole U1505C $=273.39-403.79 \mathrm{~m}$ ) is composed of gray, greenish gray, and light brownish gray clay-rich nannofossil ooze (with foraminifers) and foraminifer-rich nannofossil ooze with clay and minor amounts of nannofossil-rich clay. Unit II (Hole U1505C $=403.50-$ $480.54 \mathrm{~m}$ ) is dominated by dark greenish gray, well-consolidated silty clay and clayey silt (with nannofossils).

\section{Biostratigraphy}

All core catcher samples from Holes U1505A-U1505C were analyzed for calcareous nannofossils, planktonic foraminifers, and diatoms. Additional samples were taken from intervals in the working-half sections when necessary to refine the ages. Hole U1505D was not sampled continuously for biostratigraphic analyses because of time constraints at the end of the expedition, but the sequence recovered spans from the late Miocene to the present (Figure F26). Preservation of calcareous microfossils is good in Cores 368-U1505C-1H through 48X and moderate to poor in Cores 49X through $64 \mathrm{X}$. Planktonic foraminifers are abundant or common in Cores $1 \mathrm{H}$ through $56 \mathrm{X}$ and 59X through $62 \mathrm{X}$ and rare in Cores 57X, $58 \mathrm{X}, 63 \mathrm{X}$, and 64X. Calcareous nannofossils are generally abundant to common in most samples from Hole U1505C, except for those from the upper part of Core 57X.

Forty-five biostratigraphic datums identified in Hole U1505C suggest a continuous succession from the early Oligocene to the Holocene (Figure F26). The Pleistocene/Pliocene boundary is placed in Core $7 \mathrm{H}$, the Pliocene/Miocene boundary is placed between Cores $11 \mathrm{H}$ and $13 \mathrm{H}$, and the Miocene/Oligocene boundary is placed between Cores $54 \mathrm{X}$ and $55 \mathrm{X}$. Sedimentation rates are $\sim 7$ $\mathrm{mm} / \mathrm{ky}$ in the Oligocene, $\sim 15 \mathrm{~mm} / \mathrm{ky}$ during the Miocene-Pliocene, and $\sim 24 \mathrm{~mm} / \mathrm{ky}$ during the Pleistocene.

Relatively low abundances of planktonic foraminifers deeper than Core 57X indicate bathyal depths during the early Oligocene, whereas much higher abundances of planktonic foraminifers shallower than Core 56X suggest a deeper water environment since the late Oligocene.

\section{Paleomagnetism}

Only NRM was measured with the SRM in Hole U1505C, except for Sections $1 \mathrm{H}-1$ through $3 \mathrm{H}-1$, which were in-line AF demagnetized in three steps. Most of the 55 AF demagnetized discrete samples show very soft magnetic behavior responsible for the acquisition of a strong, vertical drilling overprint (average inclina- 
Figure F26. Lithostratigraphic and biostratigraphic summary, Site U1505.

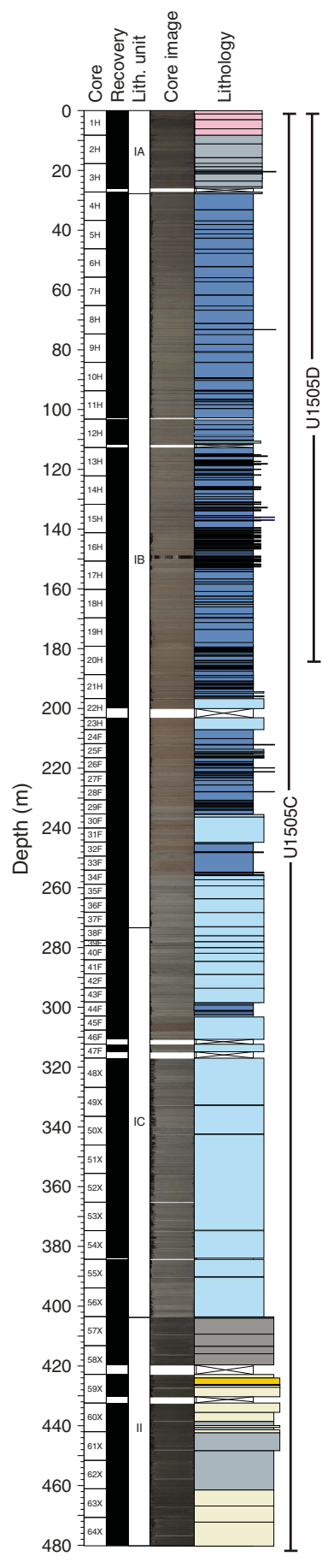

\begin{tabular}{|c|c|c|c|c|c|c|c|}
\hline \multirow{2}{*}{ 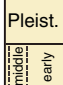 } & \multirow{2}{*}{\begin{tabular}{|c|c} 
& Plio. \\
$\frac{2}{\bar{w}}$ & $\mathbf{z}$
\end{tabular}} & \multicolumn{3}{|c|}{ Miocene } & \multicolumn{2}{|c|}{ Oligocene } & \\
\hline & & late & middle & early & late & early & 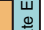 \\
\hline
\end{tabular}

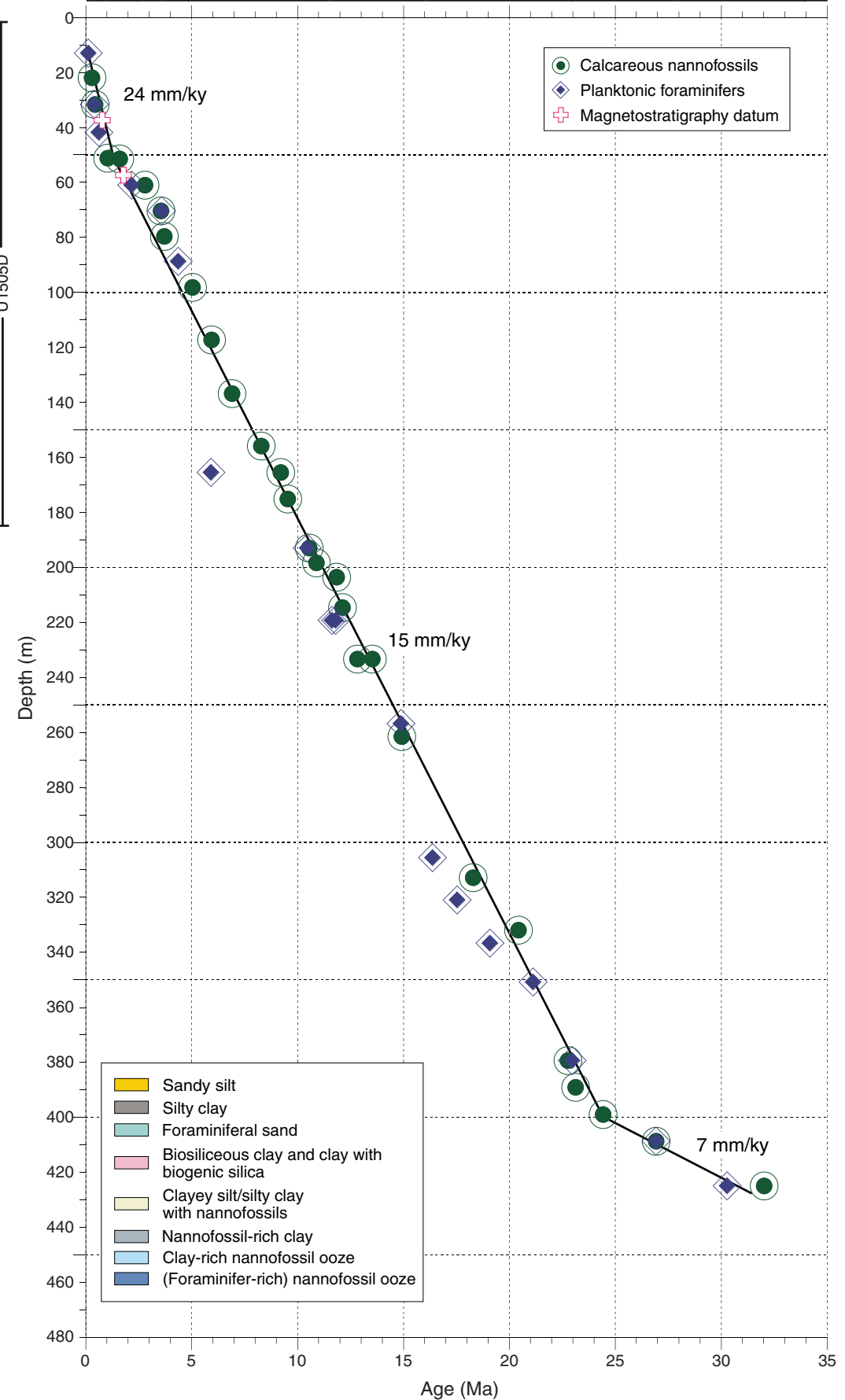

tion $=\sim 81^{\circ}$ ) that was removed by demagnetization to $10-15 \mathrm{mT}$. This soft behavior shows that magnetic remanence is dominated by multidomain to pseudosingle-domain titanomagnetite or magnetite. The drilling overprint appears to impact discrete samples far less than core sections (Figure F27). The lower part of the hole (Cores 48X through 64X) is characterized by severe drilling disturbance, which causes a large scatter of NRM directions and inclinations.
Magnetostratigraphic data are based on polarities assigned to the archive-half sections and corroborated by directions obtained from oriented discrete samples. The lower boundary of the Brunhes $(\mathrm{C} 1 \mathrm{n})$ normal chron is at $37.4 \mathrm{~m}(0.781 \mathrm{Ma})$. The lower boundary $(57.4 \mathrm{~m})$ of the reverse polarity $\mathrm{r} 1$ is the base of Subchron C1r.3r with an age of $1.778 \mathrm{Ma}$. 
Figure F27. Magnetic measurements, Hole U1505C. Inclination was used to determine polarity. AFD = AF demagnetization. Magnetostratigraphic features are referred to as $\mathrm{n} 1$, etc., in a sequential manner for convenience and have no bearing on chrons. Data from discrete samples are shown as yellow squares and green circles. GPTS2016 = geomagnetic polarity timescale of Ogg et al. (2016).

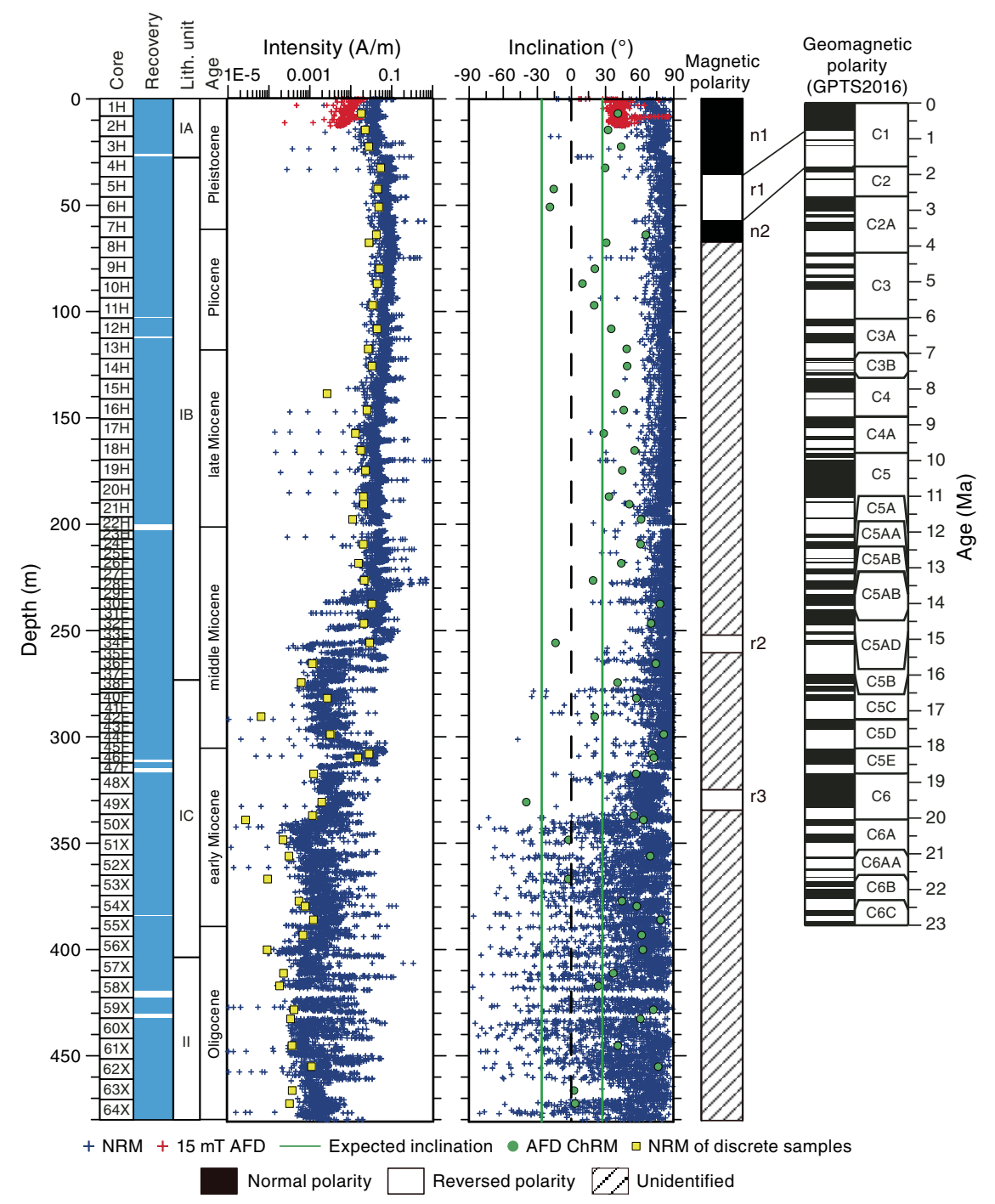

\section{Geochemistry}

Low but measurable hydrocarbon gases were detected only in Cores 368-U1505C-53X through 60X (371-438 m). The base of the hole has methane distributions similar to those at Site U1499, whereas the uppermost section is barren of methane, similar to Site U1501. Except for the shallowest $30 \mathrm{~m}$ of sediment, TOC, TN, and TS contents are mostly low in lithostratigraphic Unit I, but TS and TOC are slightly higher in Unit II; however, in all cases they are typically $<1 \mathrm{wt} \%$ (Figure F28). Interstitial water chemistry has two important features. The upper part of the hole exhibits patterns similar to those at Site U1501; inhibited sulfate reduction and low chlorine, bromine, and salinity suggest the presence of freshwater at depth. Freshwater at $>400 \mathrm{~m}$ coincides with the presence of low quantities of methane and the T60 regional seismic unconformity.

\section{Physical properties and downhole measurements}

Physical property data were acquired from cores from Holes U1505C (0-480.5 m) and U1505D (0-184 m), including density, magnetic susceptibility, $P$-wave velocity, NGR, color reflectance, and thermal conductivity. Physical property trends allow us to define two physical property units, PP Units $1(0-403 \mathrm{~m})$ and 2 (403$480 \mathrm{~m}$ ). The boundary between Units 1 and 2 displays a distinct color change from greenish and light brownish gray to dark greenish gray. This boundary, which corresponds to the seismic stratigraphic T60 unconformity, is associated with a sharp change in physical properties. In Unit 1, sediments in the upper part are composed of foraminifer-rich nannofossil ooze with clay that gradually changes to clay-rich nannofossil ooze in the lower part. This change is well reflected in the NGR, which increases with depth. The higher NGR in Unit 2 is related to sediment that primarily consists of silty clay. Magnetic susceptibility overall gradually decreases with depth. The boundary between Units 1 and 2 shows that density and $P$-wave velocity drops sharply from $\sim 2.2$ to $\sim 1.8 \mathrm{~g} / \mathrm{cm}^{3}$ and from $\sim 2250$ to $1750 \mathrm{~m} / \mathrm{s}$, respectively. Porosity abruptly increases from $\sim 35 \%$ to $\sim 50 \%$. Thermal conductivity also shows a sharp change at the boundary. Reflectance parameter $L^{*}$ and RGB data are well correlated with carbonate content. 
Figure F28. Data characterizing chemical anomalies associated with the T60 regional seismic marker, Site U1505.

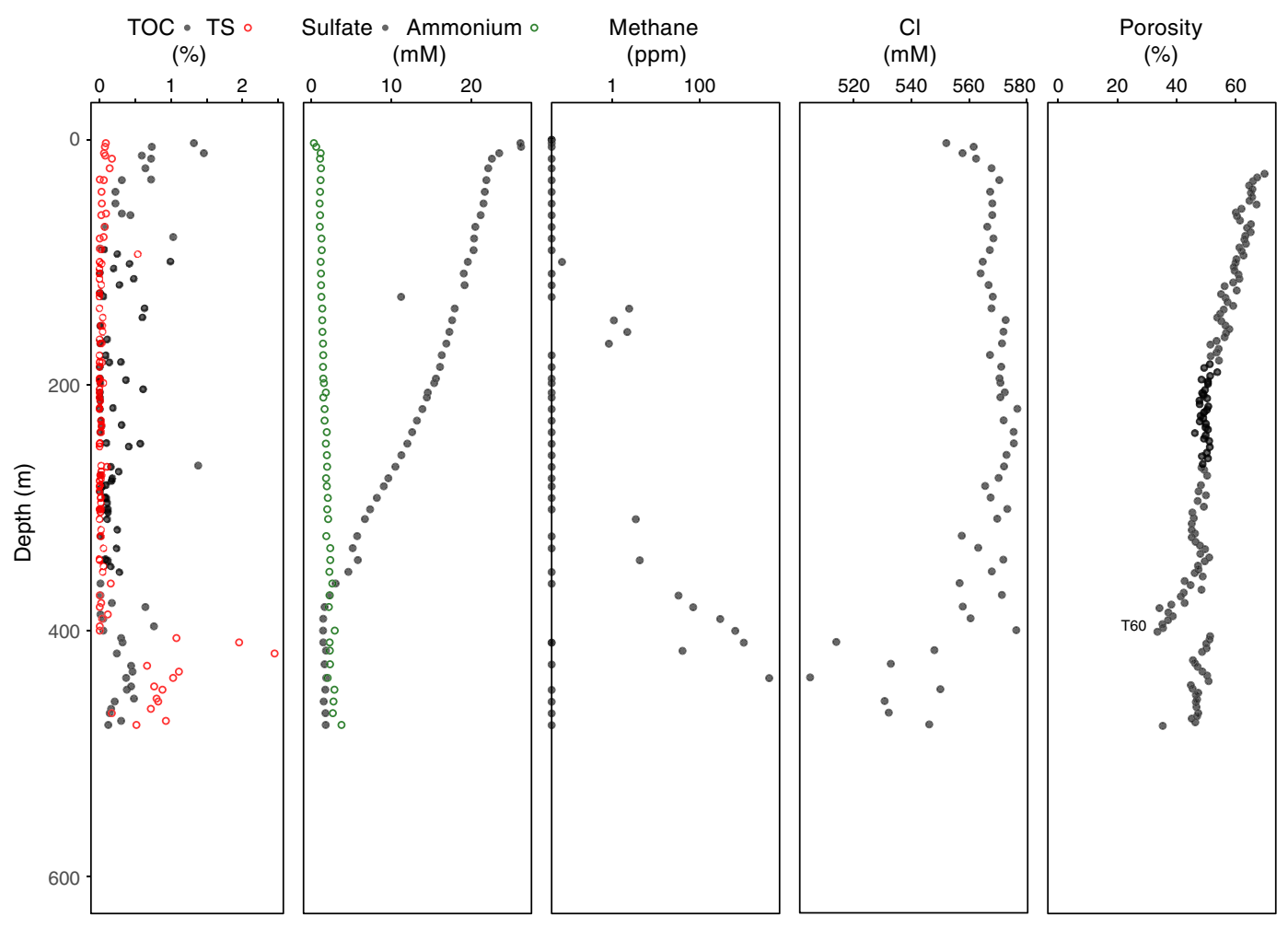

Wireline logging was conducted in Hole U1505C using the triple combo tool string, which included the HNGS, HLDS, DSI, and MSS. This logging string collected good data from $341.2 \mathrm{~m}(139.1 \mathrm{~m}$ above the bottom of Hole U1505C), which allows the definition of six logging units that mostly correlate with the lithostratigraphic units and core physical property data. Logging Unit 1 extends from the seafloor to the base of the drill pipe at $78 \mathrm{~m}$. NGR is highly attenuated inside the drill pipe. Logging Unit 2 (base of the drill pipe to $96 \mathrm{~m}$ ) exhibits NGR values that are $\sim 50 \%$ lower than the underlying logging Unit 3. In Unit 3 (96-136 m), NGR increases with depth. Logging Unit $4(136-220 \mathrm{~m})$ exhibits relatively constant $V_{\mathrm{P}}$ and $V_{\mathrm{S}}$. In logging Unit 5 (200-296 m), resistivity increases with depth, whereas most of the other physical properties are relatively constant. Logging Unit 6 (296-341.2 m) has higher magnetic susceptibility values than logging Unit 5.

Four downhole temperature measurements were conducted in Hole $\mathrm{U} 1505 \mathrm{C}$ using the APCT-3. The temperature values range from $4.7^{\circ} \mathrm{C}$ at $36.7 \mathrm{~m}$ to $11.7^{\circ} \mathrm{C}$ at $122.8 \mathrm{~m}$, giving a geothermal gradient of $84.6^{\circ} \mathrm{C} / \mathrm{km}$. A heat flow of $94.0 \mathrm{~mW} / \mathrm{m}^{2}$ was obtained from the linear fit between temperature and thermal resistance. The geothermal gradient and heat flow at Site U1505 are comparable to the relatively high values observed in a number of ODP and IODP sites in this part of the SCS.

\section{Preliminary scientific assessment}

In this section, we assess the achievements of Expedition $367 / 368$ in the SCS toward meeting the four specific objectives as stated in the Scientific Prospectus (Sun et al., 2016b). Expedition 367 followed the original drilling plan and cored into acoustic basement at Ridges A and B and progressed without significant delays. However, based on Expedition 367 results, Expedition 368 followed a modified drilling plan that included a second drill site on Ridge A. Drilling plans for Expedition 368 were further modified due to serious drilling equipment failures at deep-water Site U1503 on Ridge C (see Site U1503). This failure limited the drilling capability of the JOIDES Resolution to a maximum $3400 \mathrm{~m}$ drill string deployment from 25 May 2017 to the end of the expedition on 11 June. Only a couple of alternate drill sites could be addressed with this limit on drill string length. Two of these, both on the OMH, were implemented (Sites U1504 and U1505). Furthermore, expedition time spent from 14 to 25 May installing casing to $990 \mathrm{~m}$ for primary Site U1503 was de facto time wasted for the expedition because the site could not be completed, but it left an important drill site ready for coring in the future. The overall effects of this operational constraint are that it directed efforts more toward Objective 4 (Site U1505) than originally planned and that the tectonic high-priority Site U1503 was lost for Expedition 367/368.

\section{To determine the nature of the basement in critical crustal units across the COT of the SCS rifted margin to discriminate between different competing models of breakup at magma-poor rifted margins. Specifically, to determine whether the subcontinental lithospheric mantle was exhumed during plate rupture.}

This objective was partly achieved with the potential for a higher degree of completion during postexpedition research. However, eventually Site U1503 needs to be completed, and further efforts need to be made to understand the deep nature of Ridge A.

Site U1499 at Ridge A provided important clues to the timing of tectonism but failed to provide direct evidence for its deeper crustal composition. Site U1502, originally an alternate site to Site U1499, was therefore pursued because the nature of Ridge A was considered a very high priority and the most likely place to recover either deep crust or exhumed mantle. To give this site priority was a signif- 
icant decision and deviation from the drilling plan in the Scientific Prospectus and potentially affected our ability to address an important site on Ridge C (Site U1503).

Site U1499 on Ridge A successfully penetrated into the acoustic basement, which comprises synrift and/or postrift deposits of Oligocene or possibly older age. The clasts found in these partly coarse sediments do not contain lithologies that suggest a source of lowermost crust to exhumed mantle origin. Therefore, the nature of the deeper crust at Site U1499 remains unconstrained by direct sampling. Site U1502, also on Ridge A, recovered $180 \mathrm{~m}$ of submarine basalts of possible late Eocene to Oligocene age overlain by late Eocene/Oligocene to Miocene deep-water sediments. Onboard preliminary ICP-AES element analyses indicate they are tholeiitic basalt and are comparable to samples from the ocean crust in the SCS collected during Expedition 349 and from Site U1500 at Ridge B. However, unlike the fresh basalts of Site U1500, the Site U1502 basalts show strong fracturing and alteration by high temperature hydrothermal activity, including mineralization (e.g., massive pyrite). This difference may suggest that the deeper crust comprises plutonic bodies but does not further constrain the nature of the deep crust.

Combining the findings at Site U1502 with the recovery at Site U1499 (Expedition 367; Ridge A) of potentially rift-related syntectonic or prerift sediments suggests that Ridge A is a complex structure comprising both rift-related sediments and syntectonic igneous material. The specific question of whether upper/lower crust or subcontinental lithospheric mantle is present at depth, however, remains unanswered by coring data. Detailed examination of the recovered basalts and of the gravel unit may help constrain the specific nature of the deeper crust. Future dedicated geophysical surveying and one or two more deep drill holes will be required to firmly advance our understanding of Ridge A.

The nature of the acoustic basement below Ridge B was successfully determined at Site U1500. This site recovered $150 \mathrm{~m}$ of fresh, submarine basalts of Oligocene age in a location where seismic imaging shows a layered structure below the acoustic basement, extending to $\sim 2.5 \mathrm{~km}$ depth. The presence of a kilometer-thick carapace of basaltic lavas in the upper crust is therefore concluded. However, this carapace does not prove this $\sim 6 \mathrm{~km}$ thick crust to be entirely igneous, and its lower part conceivably could contain stretched continental lithosphere.

The nature of the crust at the $\mathrm{OMH}$ was well addressed at Site U1501. This site drilled $\sim 45 \mathrm{~m}$ into the prerift? acoustic basement beneath the Cenozoic sedimentary section and recovered lithified, coarse-grained sedimentary rocks of presumed Mesozoic age. This finding verified our predrilling interpretation of the $\mathrm{OMH}$ as comprising upper continental crustal material. The basement of the easternmost extension of the OMH was also sampled at Site U1504. In this location, greenschist facies metamorphic rock was found, suggesting that only a moderate amount $(\sim 5 \mathrm{~km})$ of upper crust was removed prior to deposition of the thin, mainly postbreakup sediments that overlie the basement. The timing of the removal of the uppermost crust is constrained to be at least before the late Eocene. Postexpedition work on age determination and thermobarometry may constrain an exhumation history and its possible relation to the Cenozoic rifting of the SCS.

Our inability to pursue deep drilling at Site U1503 obviously prevents us from characterizing the nature of the crust at Ridge $C$ based on in situ drilling data. Combining seismic interpretation and the observations from Ridge B (Site U1500), however, constrains this to be primarily if not entirely of igneous origin.

\section{To determine the time lag between plate rupture and astheno- spheric upwelling that allowed decompression melting to gener- ate igneous oceanic crust.}

This objective was achieved. The simple answer to Objective 2 is that there was no substantial time lag between (final) plate rupture and asthenospheric upwelling supporting the generation of igneous material with a basaltic, MORB-type composition. Submarine MORB-type basalts of early Oligocene age were recovered at Site U1500 on Ridge B, and based on geophysical evidence, Ridge C can be interpreted to be at least partly igneous. Seafloor magnetic anomalies C10r to C11n (29-30 Ma; approximately mid-Oligocene) encompass these two ridges and provide independent evidence of the age of the basalts from Site U1500 (Oligocene). Submarine basalts of similar or possibly slightly older age (early Oligocene to late Eocene) were found on Ridge A (Site U1502). These observations rule out any significant time-lag between final plate rupture and the onset of magmatism. Postexpedition work on mantle melting history may detail the thickness of residual subcontinental lithosphere of lithospheric thinning during breakup. Excellent material for this type of work, and for age determination, is available from Site U1500, but modeling efforts will lack the constraints from Ridge C (Site U1503) representing a more advanced stage of spreading. Because of the highly altered nature of Site U1502 basalts, geochemical studies will unfortunately be challenging but very important because these rocks likely represent a stage in margin development where continental lithosphere had a stronger impact on magmatism (contamination and by lithospheric thickness). Expedition 367/368 findings also rule out that the margin in this location was overprinted by late-stage magmatism as recently proposed.

Although the failure to pursue Site U1503 did not seriously affect our ability to constrain a possible time lag between plate rupture and onset of magmatism, it left us without a well-defined reference frame for assessing mantle composition and mantle melting conditions during steady-state accretion of igneous crust. Reoccupation of Site U1503 is therefore highly recommended to provide a benchmark against which the earlier breakup magmatism can be compared. Similarly, more and fresh basaltic material from Ridge A would greatly benefit the study of the SCS margin in terms of age determination of the earliest basaltic magmatism and its detailed geochemical elemental and isotopic composition evolution over time.

\section{To constrain the rate of extension and vertical crustal move- ments.}

This objective was partly achieved, but postexpedition work is needed to further develop our findings. Important stratigraphic control on the synrift sediments related to breakup was achieved at Sites U1499, U1501, U1502, and U1505. The findings of highly syntectonic deposits of Oligocene (and possibly older) age overlain by a very low sedimentation rate sequence of late Oligocene to early Miocene age at Ridge A (Site U1499) is strong evidence for an early Oligocene plate rupture that was completed by the latest Oligocene. This was further confirmed at Site U1501, located on the OMH. This site recovered the entire sequence of synrift sediments down to (presumed) Mesozoic basement. The sequence shows development from deltaic to shallow marine with terrigenous sedimentation (Eocene) through deepening water, yet still predominantly clastic detrital sediments (approximately early Oligocene), to deep-water marine calcareous sediments (approximately late Oligocene to Miocene). Biostratigraphic constraints on the Eocene deposits are lack- 
ing below the uppermost late Eocene sediments. A very similar evolution was documented at Site U1505 for the early Oligocene to Miocene interval. Site U1504, also at the OMH and slightly shallower than at Sites U1501 and U1505, penetrated a 120 m thick postrift sedimentary sequence above crystalline basement. Deepwater conditions were established by lowermost early Miocene time. The presence of a carbonate reef debris deposit (very shallow marine water) with an approximate age of late Eocene suggests that the $\sim 3 \mathrm{~km}$ subsidence experienced by these sediments was initiated post-late Eocene. Site U1502, also located on Ridge A, shows (minor) deep-water deposits of early Oligocene to perhaps late Eocene age followed exclusively by deep-water deposits of Oligocene to Miocene age. Deep-water conditions therefore developed earlier (pre-Oligocene) on Ridge A than on the $\mathrm{OMH}$ (approximately late Oligocene).

The inability to pursue coring at Site U1503 unfortunately prevented Expedition 368 from extending subsidence studies seaward of Ridge B (Site U1500), where the late Oligocene sediment package overlying the basalts is much better developed than at Site U1500 on Ridge B. However, the most serious lack of data needed for constraining rate of extension is the lack of biostratigraphic control in the deeper part of the Eocene section at Site U1501 and the older part of synrift or prerift deposits at Site U1499. Shallow water sediments of Eocene age similar to those at Site U1501 were found at Site U1435 (IODP Expedition 349), and, although the sediment is similarly barren of microfossils, detrital zircon is present. If also present in the Site U1501 samples, age determination on a population of these might provide maximum ages. The amount of crustal extension will be determined through a detailed tectonic interpretation of the regional seismic data (courtesy of the CNOOC) that the entire Expedition 367/368 program is based on.

\section{To improve the understanding of the Cenozoic regional tectonic and environmental development of the Southeast Asia margin and SCS by combining Expedition 367/368 results with existing $O D P / I O D P$ sediment records and regional seismic data.}

This objective was achieved, but intensive multidisciplinary postexpedition work is needed to maximize our findings. An important achievement in this regard was the recovery of a nearly continuous sequence of the prerift, synrift, and postrift sediments since the Eocene and older sediments at Site U1501. This sequence provides the sedimentary records of the SCS evolving from land to deep sea for the first time and will greatly help us to understand the sedimentary processes associated with tectonic events and paleoenvironmental development at the SCS northern margin. Together with the deep-water sediment packages from Sites U1499, U1500, U1502, and U1505, Expedition 367/368 findings provide the possible tectonic links between the SCS and the western Pacific in the aspects of the SCS formation history.

Based on the coring/drilling results of Expedition 367/368, new time-depth constraints on some of the major seismic stratigraphic unconformities are available. These unconformities were mapped regionally throughout the basin by integrating microfossil ages, petrophysics, and borehole logging data with the existing seismic reflection data. Among these seismic unconformities, the T60 unconformity is the most prominent. It is easily recognized basinwide and is present at Sites U1500, U1501, U1502, U1503 (not sampled), and U1505. Though not resolved by seismic data, its stratigraphic position is also present at Site U1499 in an extremely condensed section. Exploring its nature (e.g., timing and duration, processes, and mechanisms) is very important for understanding the regional geological evolution, but this objective will need further postexpedition work.

The postrift sediments cored during Expedition 367/368 will contribute to our understanding of the late Cenozoic tectonic and environmental history of the SCS. An early to middle Miocene succession of red claystone was found at Sites U1499, U1500, and U1502, all located deeper than $3500 \mathrm{mbsl}$. The red claystone deposits near the acoustic basement (e.g., basalt or altered basalt or gravel) extending over all of these sites indicates that the SCS basin was deep and the sedimentation rate was extremely low at that time. These conditions may correlate with a basin-wide event related to deep circulation of oxygenated water from the western Pacific prior to the closure of the Luzon Strait.

A late Miocene succession of hemipelagic and turbidite deposits was observed at deeper Sites U1499, U1500, and U1502 and likely recorded the processes that delivered sediment from the shallow shelf or slope of the northern SCS to the deeper parts of the basin. A high sedimentation rate at the deep-water sites during the late Miocene and a nearly $10 \mathrm{Ma}$ hiatus from the middle Miocene to Pleistocene observed at Site U1504 on the OMH indicate strong erosion from source areas in the upper slope and shelf region and efficient transport into the deep basin during late Miocene time.

In addition to the Oligocene to Plio-Pleistocene APC/XCB record ( 100 percent) at Site U1505, the Plio-Pleistocene sequence was recovered by double APC, high-recovery holes at Site U1505 to establish a complete record for high-resolution paleoceanographic and paleoclimatic studies. The hemipelagic deposits, rich in calcareous microfossils, at this site above the modern CCD of the SCS should enable us to reconstruct the east Asian monsoonal climate and paleoceanographic changes in the SCS at orbital and millennial timescales.

Postexpedition research using samples from Expedition 367/368 together with seismic stratigraphic correlations will continue to improve the contributions to Objective 4. This research should be channeled into four general avenues:

1. To reconstruct the early stage history of the SCS, including paleoenvironmental changes from land to deep sea and new data (e.g., detrital zircon geochronology) to constrain the sedimentary provenance,

2. To explore the paleoceanographic conditions favorable for early to middle Miocene pelagic red clay and late Miocene turbidite deposition through geochemical and geophysical techniques,

3. To correlate the chronostratigraphic records between all ODP (Leg 184) and IODP drill sites from Expedition 349 and Expedition $367 / 368$ sites in the SCS, and

4. To conduct high-resolution paleoceanographic study of Pliocene- and Pleistocene-related monsoonal climate changes and deep-water exchange between the SCS and the Pacific.

\section{Integration of drilling results with seismic data}

The large regional set of high-quality seismic data provided by the $\mathrm{CNOOC}$ formed an essential basis for the planning, scheduling, and implementation of Expedition 367/368. The continued availability of these data to the scientific party will be pivotal for postexpedition research on most of the scientific objectives discussed above. 


\section{References}

Barckhausen, U., and Roeser, H.A., 2004. Seafloor spreading anomalies in the South China Sea revisited. In Clift, P., Wang, P., Kuhnt, W., and Hayes, D. (Eds.), Continent-Ocean Interactions within East Asian Marginal Seas. Geophysical Monograph, 149:121-125. http://dx.doi.org/10.1029/149GM07

Beslier, M.-O., Whitmarsh, R.B., Wallace, P.J., and Girardeau, J. (Eds.), 2001. Proceedings of the Ocean Drilling Program, Scientific Results, 173: College Station, TX (Ocean Drilling Program). https://doi.org/10.2973/odp.proc.sr.173.2001

Boillot, G., Winterer, E.L., et al., 1988. Proceedings of the Ocean Drilling Program, Scientific Results, 103: College Station, TX (Ocean Drilling Program). https://doi.org/10.2973/odp.proc.sr.103.1988

Briais, A., Patriat, P., and Tapponnier, P., 1993. Updated interpretation of magnetic anomalies and seafloor spreading stages in the South China Sea: implications for the Tertiary tectonics of Southeast Asia. Journal of Geophysical Research: Solid Earth, 98(B4):6299-6328. https://doi.org/10.1029/92JB02280

Brune, S., Heine, C., Clift, P.D., and Pérez-Gussinyé, M., 2017. Rifted margin architecture and crustal rheology: reviewing Iberia-Newfoundland, central South Atlantic, and South China Sea. Marine and Petroleum Geology, 79:257-281. https://doi.org/10.1016/j.marpetgeo.2016.10.018

Dick, H.J.B., Lin, J., and Schouten, H., 2003. An ultraslow-spreading class of ocean ridge. Nature, 426(6965):405-412. https://doi.org/10.1038/nature02128

Doré, T., and Lundin, E., 2015. Research focus: hyperextended continental margins - knowns and unknowns. Geology, 43(1):95-96. https://doi.org/10.1130/focus012015.1

Duncan, R.A., Larsen, H.C., Allan, J.F., et al., 1996. Proceedings of the Ocean Drilling Program, Initial Reports, 163: College Station, TX (Ocean Drilling Program). https://doi.org/10.2973/odp.proc.sr.163.1999

Eldholm, O., Gladczenko, T.P., Skogseid, J., and Planke, S., 2000. Atlantic volcanic margins: a comparative study. In Nottvedt, A. (Ed.), Dynamics of the Norwegian Margin. Geological Society Special Publication, 167(1):411428. https://doi.org/10.1144/GSL.SP.2000.167.01.16

Franke, D., Savva, D., Pubellier, M., Steuer, S., Mouly, B., Auxietre J.-L., Meresse, F., and Chamot-Rooke, N., 2013. The final rifting evolution in the South China Sea. Marine and Petroleum Geology, 58(Part B):704-720. https://doi.org/10.1016/j.marpetgeo.2013.11.020

Geoffroy, L., 2005. Volcanic passive margins. Comptes Rendus Geoscience, 337(16):1395-1408. https://doi.org/10.1016/j.crte.2005.10.006

Huismans, R., and Beaumont, C., 2011. Depth-dependent extension, twostage breakup and cratonic underplating at rifted margins. Nature, 473(7345):74-78. https://doi.org/10.1038/nature09988

Huismans, R.S., and Beaumont, C., 2008. Complex rifted continental margins explained by dynamical models of depth-dependent lithospheric extension. Geology, 36(2):163-166. https://doi.org/10.1130/G24231A.1

Lester, R., McIntosh, K., Van Avendonk, H.J.A., Lavier, L., Liu, C.-S., and Wang, T.K., 2013. Crustal accretion in the Manila trench accretionary wedge at the transition from subduction to mountain-building in Taiwan. Earth and Planetary Science Letters, 375:430-440. https://doi.org/10.1016/j.epsl.2013.06.007

Li, C.-F., Lin, J., and Kulhanek, D.K., 2013. Expedition 349 Scientific Prospectus: South China Sea Tectonics. International Ocean Discovery Program. https://doi.org/10.2204/iodp.sp.349.2013

Li, C.-F., Lin, J., Kulhanek, D.K., Williams, T., Bao, R., Briais, A., Brown, E.A., Chen, Y., Clift, P.D., Colwell, F.S., Dadd, K.A., Ding, W., HernándezAlmeida, I., Huang, X.-L., Hyun, S., Jiang, T., Koppers, A.A.P., Li, Q., Liu, C., Liu, Q., Liu, Z., Nagai, R.H., Peleo-Alampay, A., Su, X., Sun, Z., Tejada, M.L.G., Trinh, H.S., Yeh, Y.-C., Zhang, C., Zhang, F., Zhang, G.-L., and Zhao, X., 2015a. Expedition 349 summary. In Li, C.-F., Lin, J., Kulhanek, D.K., and the Expedition 349 Scientists, South China Sea Tectonics. Proceedings of the International Ocean Discovery Program, 349: College Station, TX (International Ocean Discovery Program).

https://doi.org/10.14379/iodp.proc.349.101.2015
Li, C.-F., Lin, J., Kulhanek, D.K., Williams, T., Bao, R., Briais, A., Brown, E.A., Chen, Y., Clift, P.D., Colwell, F.S., Dadd, K.A., Ding, W., HernándezAlmeida, I., Huang, X.-L., Hyun, S., Jiang, T., Koppers, A.A.P., Li, Q., Liu, C., Liu, Q., Liu, Z., Nagai, R.H., Peleo-Alampay, A., Su, X., Sun, Z., Tejada, M.L.G., Trinh, H.S., Yeh, Y.-C., Zhang, C., Zhang, F., Zhang, G.-L., and Zhao, X., 2015b. Site U1435. In Li, C.-F., Lin, J., Kulhanek, D.K., and the Expedition 349 Scientists, South China Sea Tectonics. Proceedings of the International Ocean Discovery Program, 349: College Station, TX (International Ocean Discovery Program). https://doi.org/10.14379/iodp.proc.349.107.2015

Li, C.-F., Wang, P., Franke, D., Lin, J., and Tian, J., 2012a. Unlocking the opening processes of the South China Sea. Scientific Drilling, 14:55-59. https://doi.org/10.2204/iodp.sd.14.07.2012

Li, C.-F., Xu, X., Lin J., Sun, Z., Zhu, J., Yao, Y., Zhao, X., Liu, Q., Kulhanek, D.K., Wang, J., Song, T., Zhao, J., Qiu, N., Guan, Y., Zhou, Z, Williams, T., Bao, R., Briais, A., Brown, E.A., Chen, Y., Clift, P.D., Colwell, F.S., Dadd, K.A., Ding, W., Hernández Almeida, I., Huang, X.-L., Hyun, S., Jiang, T., Koppers, A.A.P., Li, Q., Liu, C., Liu, Z., Nagai, R.H., Peleo-Alampay, A., Su, X., Tejada, M.L.G., Trinh, H.S., Yeh, Y.-C., Zhang, C., Zhang, F., and Zhang, G.-L., 2014. Ages and magnetic structures of the South China Sea constrained by deep tow magnetic surveys and IODP Expedition 349. Geochemistry, Geophysics, Geosystems, 15(12):4958-4983. https://doi.org/10.1002/2014GC005567

Li, J., Ding, W., Wu, Z., Zhang, J., and Dong, C., 2012b. The propagation of seafloor spreading in the southwestern subbasin, South China Sea. Chinese Science Bulletin, 57(24):3182-3191.

https://doi.org/10.1007/s11434-012-5329-2

McIntosh, K., Lavier, L., van Avendonk, H., Lester, R., Eakin, D., and Liu, C.-S., 2014. Crustal structure and inferred rifting processes in the northeast South China Sea. Marine and Petroleum Geology, 58(Part B):612-626. https://doi.org/10.1016/j.marpetgeo.2014.03.012

McIntosh, K., van Avendonk, H., Lavier, L., Lester, W.R., Eakin, D., Wu, F., Liu, C.-S., and Lee, C.-S., 2013. Inversion of a hyper-extended rifted margin in the southern Central Range of Taiwan. Geology, 41(8):871-874. https://doi.org/10.1130/G34402.1

Ogg, J.G., Ogg, G., and Gradstein, F.M., 2016. A Concise Geologic Time Scale 2016: Boston (Elsevier).

Pérez-Gussinyé, M., Phipps Morgan, J., Reston, T.J., and Ranero, C.R., 2006. The rift to drift transition at non-volcanic margins: insights from numerical modelling. Earth and Planetary Science Letters, 244(1-2):458-473. https://doi.org/10.1016/j.epsl.2006.01.059

Pérez-Gussinyé, M., and Reston, T.J., 2001. Rheological evolution during extension at nonvolcanic rifted margins: onset of serpentinization and development of detachments leading to continental breakup. Journal of Geophysical Research: Solid Earth, 106(B3):3961-3975. https://doi.org/10.1029/2000JB900325

Reston, T.J., 2009. The structure, evolution and symmetry of the magma-poor rifted margins of the North and Central Atlantic: a synthesis. Tectonophysics, 468(1-4):6-27. https://doi.org/10.1016/j.tecto.2008.09.002

Seton, M., Whittaker, J.M., Wessel, P., Müller, R.D., DeMets, C., Merkouriev, S., Cande, S., Gaina, C., Eagles, G., Granot, R., Stock, J., Wright, N., and Williams, S.E., 2014. Community infrastructure and repository for marine magnetic identifications. Geochemistry, Geophysics, Geosystems, 15(4):1629-1641. https://doi.org/10.1002/2013GC005176

Shi, H., and Li, C.-F., 2012. Mesozoic and early Cenozoic tectonic convergence-to-rifting transition prior to opening of the South China Sea. International Geology Review, 54(15):1801-1828. https://doi.org/10.1080/00206814.2012.677136

Shipboard Scientific Party, 2000. Leg 184 summary: exploring the Asian monsoon through drilling in the South China Sea. In Wang, P., Prell, W.L., Blum, P., et al., Proceedings of the Ocean Drilling Program, Initial Reports, 184: College Station, TX (Ocean Drilling Program), 1-77. https://doi.org/10.2973/odp.proc.ir.184.101.2000

Sun, Z., Liu, S., Pang, X., Jiang, J., and Mao, S., 2016a. Recent research progress on the rifting-breakup process in passive continental margins. Journal of Tropical Oceanography, 35(1):1-16. (in Chinese with English abstract) https://doi.org/10.11978/2015030 
Sun, Z., Stock, J., Jian, Z., McIntosh, K., Alvarez Zarikian, C.A., and Klaus, A., 2016b. Expedition 367/368 Scientific Prospectus: South China Sea Rifted Margin. International Ocean Discovery Program. https://doi.org/10.14379/iodp.sp.367368.2016

Sun, Z., Xu, Z., Sun, L., Pang, X., Yan, C., Li, Y., Zhao, Z., Wang, Z., and Zhang, C., 2014. The mechanism of post-rift fault activities in Baiyun sag, Pearl River Mouth Basin. Journal of Asian Earth Sciences, 89:76-87. https://doi.org/10.1016/j.jseaes.2014.02.018

Sutra, E., and Manatschal, G., 2012. How does the continental crust thin in a hyperextended rifted margin? Insights from the Iberia margin. Geology, 40(2):139-142. https://doi.org/10.1130/G32786.1

Wang, T.K., Chen, M.-K., Lee, C.-S., and Xia, K., 2006. Seismic imaging of the transitional crust across the northeastern margin of the South China Sea. Tectonophysics, 412(3-4):237-245. https://doi.org/10.1016/j.tecto.2005.10.039

Wei, X.-D., Ruan, A.-G., Zhao, M.-H., Qiu, X.-L., Li, J.-B., Zhu, J.-J., Wu, Z.-L., and Ding, W.-W., 2011. A wide-angle OBS profile across the Dongsha uplift and Chaoshan depression in the mid-northern South China Sea. Chinese Journal of Geophysics, 54(6):1149-1160.

https://doi.org/10.1002/cjg2.1691
Whitmarsh, R.B., Manatschal, G., and Minshull, T.A., 2001. Evolution of magma-poor continental margins from rifting to seafloor spreading. Nature, 413(6852):150-154. https://doi.org/10.1038/35093085

Whitmarsh, R.B., Sawyer, D.S., Klaus, A., and Masson, D.G. (Eds.), 1996. Proceedings of the Ocean Drilling Program, Scientific Results, 149: College Station, TX (Ocean Drilling Program).

https://doi.org/10.2973/odp.proc.sr.149.1996

Yan, P., Zhou, D., and Liu, Z., 2001. A crustal structure profile across the northern continental margin of the South China Sea. Tectonophysics, 338(1):1-21. https://doi.org/10.1016/S0040-1951(01)00062-2

Zhou, D., Sun, Z., Chen, H., Xu, H., Wang, W., Pang, X., Cai, D., and Hu, D., 2008. Mesozoic paleogeography and tectonic evolution of South China Sea and adjacent areas in the context of Tethyan and Paleo-Pacific interconnections. Island Arc, 17(2):186-207. https://doi.org/10.1111/j.1440-1738.2008.00611.x

Zhou, X.M., and Li, W.X., 2000. Origin of late Mesozoic igneous rocks in southeastern China: implications for lithosphere subduction and underplating of mafic magmas. Tectonophysics, 326(3-4):269-287. https://doi.org/10.1016/S0040-1951(00)00120-7 